\title{
Surface Geophysical Exploration - Compendium Document
}

Author Name: D.F. Rucker, hydroGEOPHYSICS, inc.

Columbia Energy and Environmental Services, Inc.

Washington River Protection Solutions, LLC

Richland, WA 99352

U.S. Department of Energy Contract DE-AC27-08RV14800

$\begin{array}{lll}\text { EDT/ECN: } & \text { DRF } & \text { UC: } \\ \text { Cosi Center: } & & \text { Charge Code: } \\ \text { B\&R Code: } & & \text { Tatal Pages: } 66\end{array}$

Key Words: Surface Geophysical Exploration, SGE, Compendium Docurnent,

Abstract. This report documents the evolution of the surface geophysical exploration program and highlights some of the most recent successes in imaging conductive targets related to past leaks within and around Hanford's tank farms.

TRADEMARK DISCLAIMIER. Reterence hereln to any spectific commercial product, process, or service by trade name, trademark, menufacturer, or ptherwiso, does not necesedrily conotitute or imply its endorserment, recormmendation, or faworing by the United States Govemment or any agency thereof or its contraciors or subcoritractors

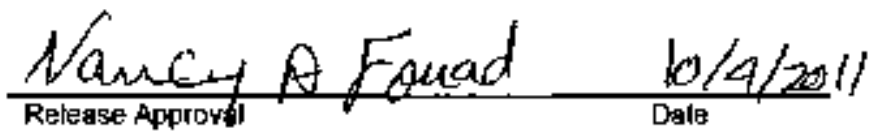

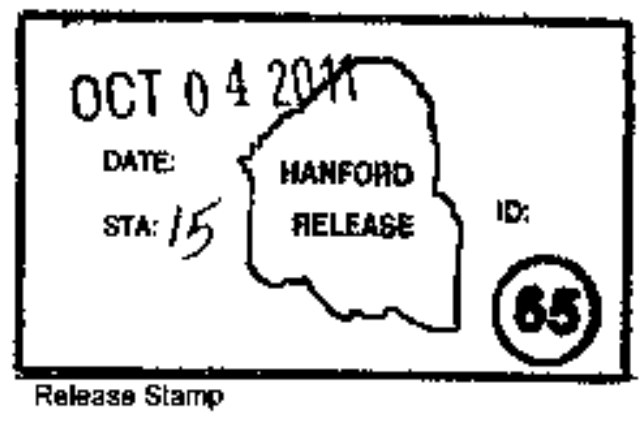

Approved For Public Release 


\section{TABLE OF CONTENTS}

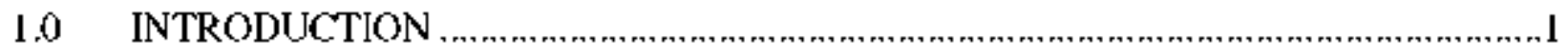

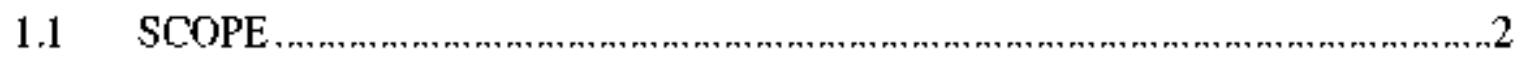

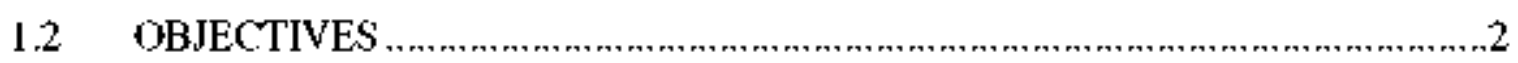

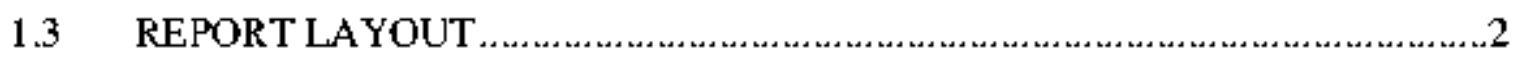

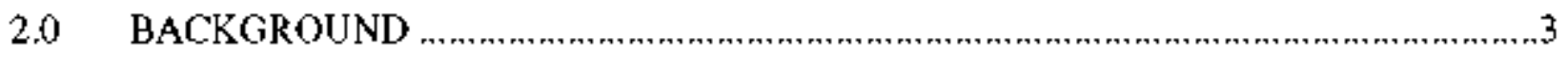

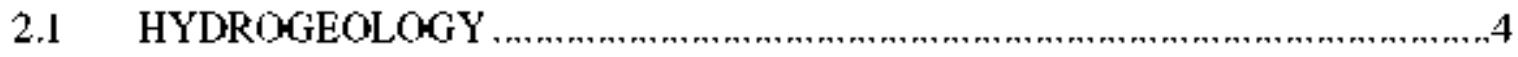

2.1.1 Setting and Physiogaphy .................................................................4

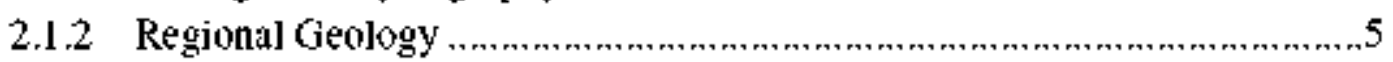

2.1.3 Geology and Hyitrogeology of the Hantord Site ................................6

2.2 TANK FARM DESCRIPTIONS

2.2.1 A/AX Tank Farms

2.2 .2 B/BX/BY Tank Farms ...........................................................10

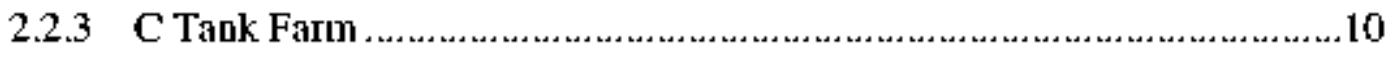

2.2.4 T/TX/TY Tank Farms ....................................................................

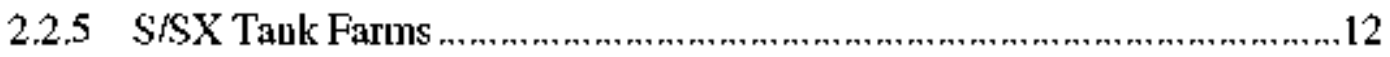

$2.2 .6 \mathrm{U}$ Tank Farm ................................................................................ 13

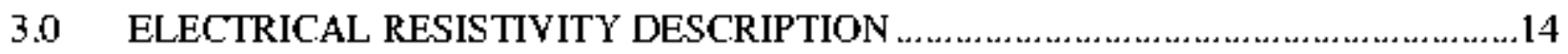

3.1 ELECTRICAL RESISTIVITY IN INDUSTRIALIZED AREAS ..................16

3.2 VALIDATION OF THE LONG ELECTRODE METHOD ….........................18

3.2.1 Experimental Site ............................................................................ 18

3.2.2 Experimental Design ....................................................................19

3.2 .3 Point Electrode Validation .................................................................

3.2.4 Long Electrode Validation...................................................27

3.2 .5 Summary of Validation ...............................................................

4.0 MAPPING WASTE SITES WITH MINIMAL INFRASTRUCTURE

5.0 MAPPING WASTE SITES WITH COMPLEX INFRASTRLICTURE ….........................37

5.I TANK FARM CHARACTERIZATION ...........................................

5.1.1 Characterization with Wells as Long Electrodes ..................................38

5.1.2 Characterization with Buried Electrodes ..................................................41

5.2 TANK FARM LEAK MONITORING ……..................................................43

6.0 SGE PROGRAM EVOLUTION

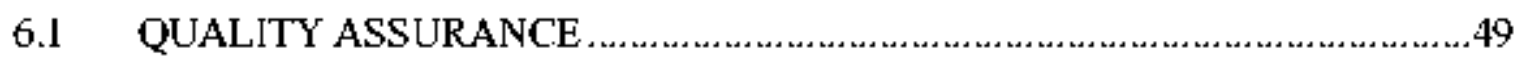

6.1.1 CALIBRATION AND MAINTENANCE OF EQUIPMENT AND

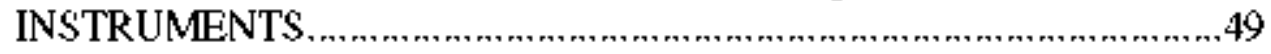

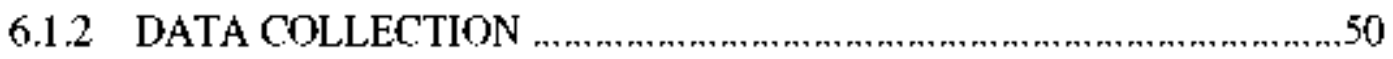

6.1.3 ELECTRICAL INTERFERENCE MONITORING ...............................50 


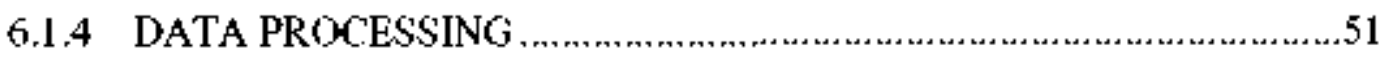

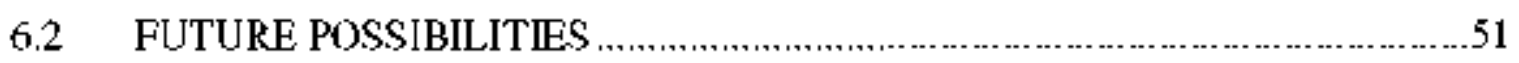

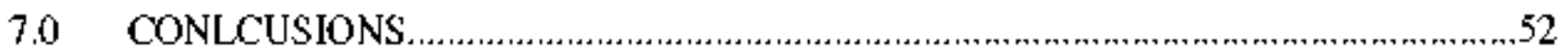

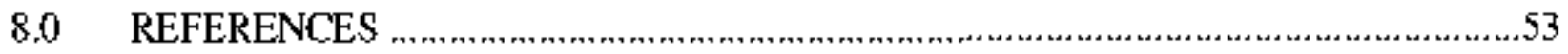

\section{LIST OF FIGURES}

1. Schematic of the C Tank Farm in the 200 East Area of Hanford Showing Subsurface lnfrastructure .................................................4

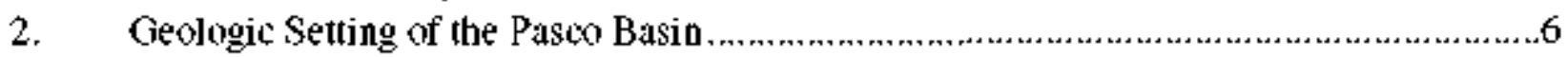

3. Generalized Stratigraphy of the Pasco Basin and Vicinity …........................................ 7

4. Layout of Electrodes for Conducting Electrical Resistivity Characterization .....................15

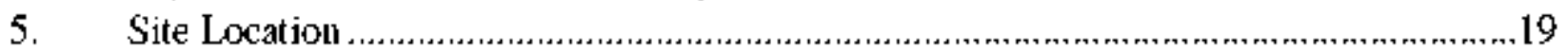

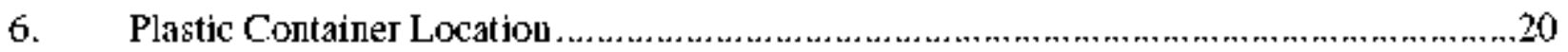

7. Data and Inversion Results from the Point Electrodes .........................................23

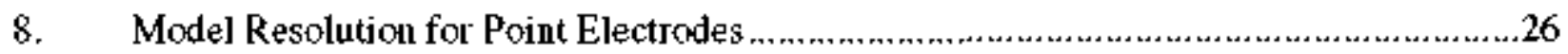

9. Electrical Data Statistics from the Long Electrodes Using the Pole-Pole Array ..............27

10. Inversion Results for the LE-ERT for the Pole-Pole Altay ...............................29

11. Electrical Data Statistics for the Long Electrode using Pole-Dipole (PD) and Dipole-Dipole (DD) Arrays .......................................................31

12. Inversion Results for the LE-ERT for the PD and DD Anays ...................................32

13. Site Map and Location of the BCCT on the Hanford Site .........................................35

14. Three-Dimensional Electrical Resistivity Results of the BX Trenches.........................36

15. Examples of Metallic Infrastructure in Electrical Resistivity lmages ............................38

16. Modeling Results For The C. Tank Farm Using Both Long Electrodes (Wells) and Point Electrodes Along the Periphery of the Tank Farm .............................................40

17. Three-Dimensional Resistivity of the BY Tank Farm …...........................................42

18. The Location of the S Tank Farm Within 200

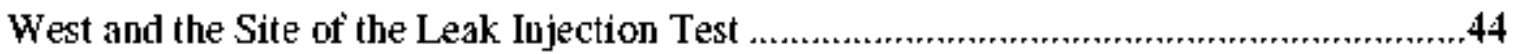

19. Apparent Resistivity Data Acquired in the $S$ Tank Farm Hanford Using Long Electrodes ........................................................45

20. Results of Time Lapsed Modeling of Long Electrode Data .....................................46

21. Resistivity of a Model Cell $8 \mathrm{~m}$ South of the Injection Site Versus Time Lapsed Paratmeter, a .....................................................47

22. Evolutionary Time Scale of the Application of Resistivity at the Hanford Sile...............48

\section{LIST OF TABLES}

1. Statistics for the Point Electrode Inversions 


\section{LIST OF TERMS}

\begin{tabular}{ll} 
Abbreviations and Acronyms \\
2D & two-diminsional \\
3D & three-dimensional \\
BCCT & BC cribs and trenches \\
CCU1 & lower subunit of the Cold Creek unit \\
CCUu & upper subunit of the Cold Creek unit \\
CRBG & Miocene Columbia River Basalt Group \\
DD & dipole-dipole \\
DOE & U.S. Department of Energy \\
EPA & Environmental Protection Agency \\
GF & geometric factor \\
HFFACO & Hauford Federal Facility Agreement and Consent Order \\
HGI & hydroGEOPHYSICS, Inc. \\
LE-ERT & Long Electrode Electrical Resistivity Tomography \\
MARS & Mobile Arm Retrieval System \\
PD & pole-dipole \\
PNNL & Pacific Northwest National Laboratory \\
PP & pole-pole \\
PUREX & Plutonium-Uraniun Extraction \\
QA & quality assurance \\
REDOX & Reduction-Oxidation \\
SGE & sulface geophysical exploration \\
SST & single-shelled tank \\
T farm & T tank farm \\
UPR & unplanned release \\
USB & universal serial bus \\
WMA & waste management area \\
WRPS & Washington River Protection Solutions, LLC \\
WST & waste storage tank \\
YFB & Yakima Fold Belt \\
\hline
\end{tabular}


RPP-RPT-50452, Rew . 0

$\begin{array}{ll}\text { Units } & \\ \mu \mathrm{S} / \mathrm{cm} & \text { microsiemens per centimeter } \\ \mathrm{cm} & \text { centimeter } \\ \mathrm{ft} & \text { foot } \\ \mathrm{gal} & \text { gallon } \\ \mathrm{ha} & \text { hectacre } \\ \mathrm{k}_{\mathrm{d}} & \text { partition coefficient } \\ \mathrm{km} & \text { kilomeler } \\ \mathrm{km}^{2} & \text { kilometer squared } \\ \mathrm{km} & \text { kilometer cubed } \\ \mathrm{L} & \text { liter } \\ \mathrm{m} & \text { meter } \\ \mathrm{m}^{3} & \text { meter cubed } \\ \mathrm{mg} / \mathrm{L} & \text { milligrams per liter } \\ \mathrm{pCi}^{3} \mathrm{~g} & \text { picocurie per gram } \\ \mathrm{ppm} & \text { part per million } \\ \mathrm{s} & \text { second }\end{array}$




\subsection{INTRODUCTION}

This seport documents the evolution of the surface geophysical exploration (SGE) program and highlights some of the most recent successes in imagiug conductive targets related to past leaks within and around Hanford's tank farms. While it is noted that the SGE program consists of multiple geophysical techniques designed to 1 ) locate near surface infrastructure that may interfere with 2) subsulface plume mapping, the report will focus primarily on electrical resistivity acquisition and processing for plume mapping. Accompanying this report is a peer reviewed journal article submitted to Environmental Monitoring and Assessment (WRPS-50043, Surface Geophysical Exploration: Developing Noninvasive Tools to Monitor Past Leaks around Hanford's Tank Farms).

The SGE progran was initiated in 2005 to image the 24I-T tank farm (T farm) (RPP-RPT-28955. Surface Geopinsical Exploration of T Tank Fam at the Hanford Site). The initial acjuisition strategy at $\mathrm{T}$ farm was the same as that applied at the BC Cribs and Trenches site (see Rucker et al., 2009. "Three-Dimensional Electrical Resistivity Model of a Nuclear Waste Disposal Site ${ }^{41}$ ), namely parallel and otthogonal profiles of electrical resistivity across the leugth of the farm and over adjacent waste sites (e.g., 216-T-7, 216-T-32, 216-T-14, etc.). Due to the interferences from the near surface piping network, tanks, fences, wells. etc., the results of the three-dimensional (3D) reconstruction of electrical resistivity was more representative of metal than the high ionic strength plumes.

Since the first deployment, the focus of the SGE program has been to acquire and model the best electrical resistivity data that minimizes the influence of buried metal objects. Towald that goal, two significant advances have occurred: 1) using the infrastructure directly in the aciusition campaign and 2) placement of electrodes beneath the infrastructure. The direa use of infrastructure was successfully demonstrated at $T$ farm by using wells as long electrodes (Rucker et al.. 2010, "Electrical-Resistivity Characterization of an Industrial Site Using Long Electrodes"). While the method was capable of finding targets related to past releases. a loss of vertical resolution was the trade-off. The burying of electrodes below the infrastructure helped to increase the vertical resolution, as long as a sufficient number of electrodes are available for the acquisition campaign. Recent projects conducted in the BY tank farm (RPP-RPT-49129, Three-Dimensional Surface Geophysical Exploration of the BY Tant Farm) and around the C tank farm (RPP-R PT-50052. Surface Geoplysical Exploration of UPR-200-E-82 Neat the C Tank Farm) have shown that a large number of buried electrotes (upwards of 50-100) can siguificautly increase the ability to image subsurface plumes in the tanks farms.

Finally, looking forward, the SGE program has more opportunities for increasing the utility of electrical resistivity measurements for use in and around the tank farms. For example, hydroGEOPHYSICS, Inc. (HGI) is developing a new resistivity acquisition system with a siguificautly larger number of channels that could be deployed for monitoring an entire tank farm during waste retrieval operations (cumently, a few tanks are monitored with a 30 channel system). The increased number of channels would provide for a larger number of sampling locations, giving a greater contex 1 to leaks that may occur in the vadose zone. The system could then stay in place for louger term monitoring after tank farm closure to ensure barrier integrity, 
confirm waste migration pathways, and provide a level of assurance that is unattainable with non-geophysical methods. Additional acquisition strategies, such as induced polarization (a measure of capacitance of the ground) and complex resistivity (resistivity collected as a function of input frequency) could be employed within the tank farms (using wells or point electrodes) to gather additional data that may be related to biogeochemical phenomena. It is well known that oxidation-reduction reactions, microbial activity, and geochemical speciation can produce electrical signatures that can be measured with these more advanced techuiques (Cassiani. et. al., 2009. "A Saline Trace Test Monitored via Time-Lapse Sulface Electrical Resistivity Tomography:" Martinho, et. al., 2010 . "An Experimental Study of the Diese] Biodegradation Effects on Soil Biogeophysical Parameters:" Ntarlagiannis, et. al., 2005. "Low-Frequency Electrical Response to Microbial Induced Sulfide Precipitation;" Vaudelet, et. al., 2010, "Induced Polarization Signatures of Cations Eshibiting Differential Somtion Behaviors in Saturated Sands:" and Vaudelet et. a]., 2011. "Changes In Induced Polarization Associated With the Sorption of Sodium, Lead, and Zinc on Silica Sands").

\subsection{SCOPE}

The scope of this report is to cover past SGE projects and provide an overview of how the method has been used successfully in Hanford's tank farm environments to image past releases.

\subsection{OBJECTIVES}

The main objective of the cutrent work was to provide an overview of SGE on the Hanford Site.

\subsection{REPORT LAYOUT}

This report is divided into several main sections.

- Section 1.0. Introduction - Describes the scope and objectives of the investigation.

- Section 2.0. Backgronud Setting - Describes the setting of tank farms. with geology and hydrology. and information regarding the disposal activities in and around the tank farms.

- Section 3.0, Electrical Resistivity - Discusses the application of the resistivity method for tank farms.

- Section 4.0. Mapping Waste Sites with Minimal Infrastructure - Discusses briefly the acquisition methodotogy and processing of the geophysical data around trenches and cribs.

- Section 5.0, Mapping Complex Waste Sites with Infrastructure - Presents results from resistivity surveying in tank farms.

- Section 6.0, SGE Program Evolution - Provides an overview of the program with improvements.

- Section 7.0. Conclusions and Recommendations - Provides conclusions and recommendations for improving follow-on SGE efforts.

- Section 8.0, References - Lists reference documents cited in the report. 


\subsection{BACKGROUND}

The Hanford Site in southeastem Washington has 177 underground liquid waste storage tanks (WST) with nearly $2.1 \times 10^{8}$-L of radioactive legacy waste generated fron plutoniun production for nuclear weapons. Of these, 67 single-shell tanks (SST) are known or suspected as having leaked, possibly releasing an estimated $4 \times 10^{6}$ Liters (L) of radioactive fluids into the vadose zone (Gephart and Lundgren. 1995. Hanford Tank Clean Up: A Guide to Inderstandintg the Techtical Issues).

The SSTs are grouped together in twelve tank farms, which are highly conplex industrial areas with below ground tanks, piping networks, distribution manifolds, and diversion boxes needed to move the waste from the generating plant to specific tanks, electricity distribution networks, and other waste retrieval infrastructure. As an example, Figure 1 shows the complexity of subsurface infrastructure within the $C$ tank farm. The $C$ tank farm contains 16 SST of various sizes, the largest of which are $2 \times 10^{6} \mathrm{~L}$. The tank farm also has an extensive below-ground piping network. dry wells, and buildings.

The $\mathrm{C}$ tank farm received and transferred waste between several processing plants and other tank farms, including the B Plant (approximately 1.500 meters [m] west), the Plutonium-Uranium Extraction (PUREX) Plant ( $900 \mathrm{~m}$ south), and U plant ( $8,000 \mathrm{~m}$ west). As a result of transferring liquid waste from these plants via an intricate pipeline network, a number of discharge and overflow events occurred, where waste was introduced to the vadose zone (the water table is approximately $76 \mathrm{~m}$ below ground surface). Waste discharges at $\mathrm{C}$ tank farm include planned releases. where liguid waste was discharges to various facilities. such as septic fields and reverse wells. Unplanned releases (UPRs) have also occurred, including tank leaks, transfer line leaks operations spills and overfills. These are described in RPP-ENV-33418, C Farm Leak Assessments Report: 241.C-101, 241-C.110, 241-C-111, 241-C.105, and Unptanted Waste Releases.

The composition of the waste varies across the site among the various tank farms, as well as among individual tanks in a single tank farm, based on the different processes that occurred to chemically strip the plutonium from the uranium fuel rods. Both weapons and fuel grade plutonium were produced from 1944 to 1990 and five different plants were constructed to facilitate the plutonium production. T and B Plant were primarily used through 1956. The Reduction-Oxidation (REDOX) and PUREX Plants began operation in the 1950s, possessing both higher efficiency and safer extraction technologies (Gephart, 2010, "A Short Histcry of Waste Management at the Hanford Site"). The fifth plant, U Plant. operated between 1952 and 1958 to recover uranium from tank waste. In total. Hanford processed nearly $97 \times 10^{3}$ metric 1ons of uranium using chemical precipitation and solvent extraction techniques (Gephart, 2010). As a result, the waste stored in tanks is usually a mixlure of highly saline waste with heavy metals and radiological constituents. Table 3 of Zachara et al., 2007, "Geochenical Processes Controlling Migration of High Level Wastes in Hanford's Vadose Zone" lists waste products in three tanks across the site, which exhibit relatively high molar concentrations of sodium, nitrate, uranium. cesium, strontium, and technetium. Electrically, this waste has an extremely high conductivity of about $10^{5}$ microsiemens per centimeter $(\mu \mathrm{S} / \mathrm{cm})$ (or electrical resistivity of $0.06 \mathrm{obn}-\mathrm{m}$ ). When introduced to the ground, the electrical resistivity of the waste is several orders of magnitude less than the surrounding formation. which tends to be a dry sand 
to gravelly sand with high electrical resistivity (upwards to $1500 \mathrm{ohm}-\mathrm{m}$ ). Electrical and electromagnetic geophysical techniques can take advantage of this contrast in properties to map the extent of discharges to the ground.

\section{Figure 1. Schematic of the C Tank Farm in the 200 East Area of Hanford Showing Subsurface Infrastructure.}

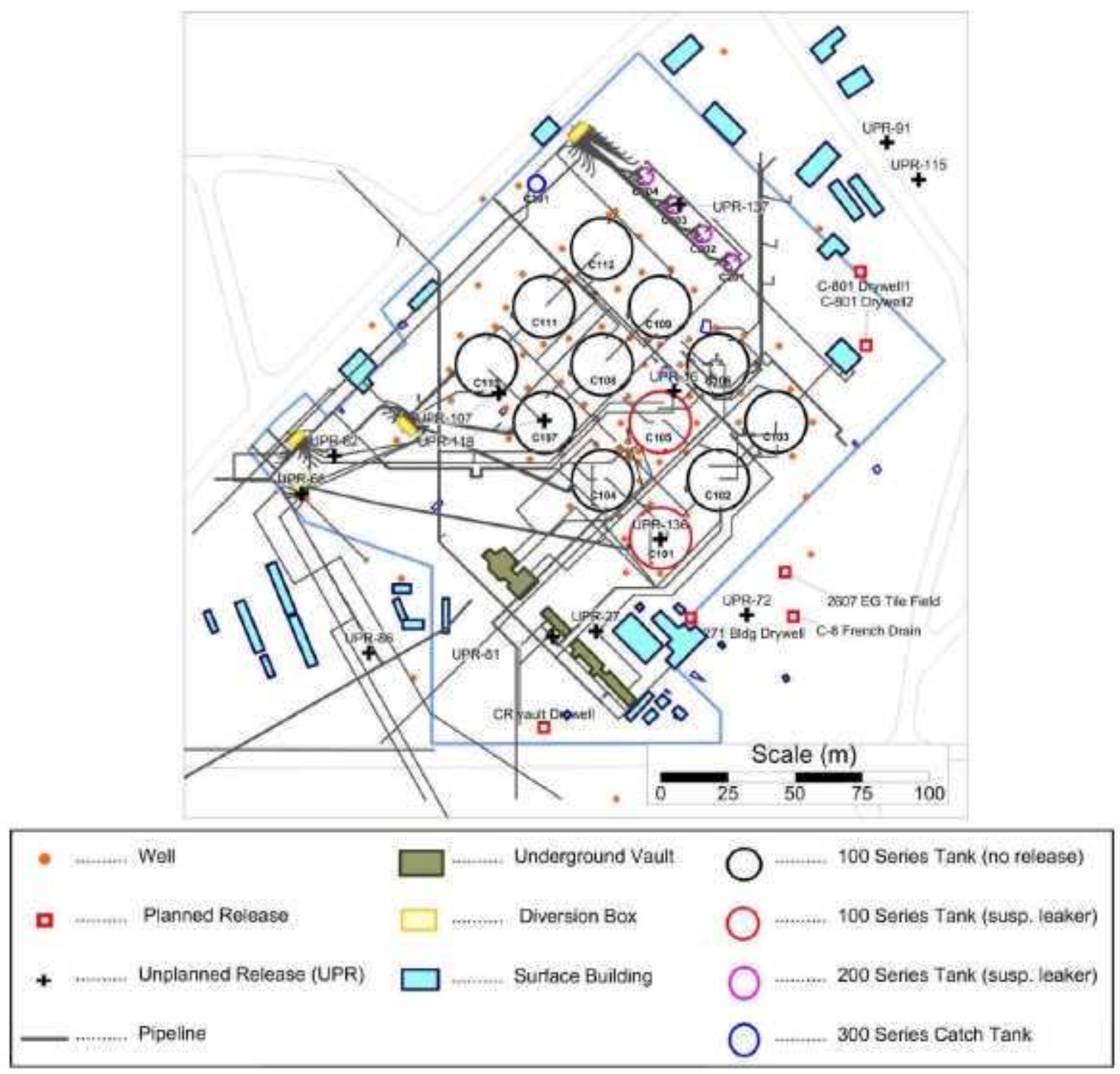

\subsection{HYDROGEOLOGY}

\subsubsection{Setting and Physiography}

The Hanford Site lies within the Columbia Plateau; a broad plain situated between the Cascade Range to the west and the Rocky Mountains to the east, and is underlain by the Miocene Columbia River Basalt Group (CRBG). The northern Oregon and Washington portion of the 
Columbia Plateau is often called the Columbia Basin due to the formation of a broad lowland surrounded on all sides by mountains. In the central and western parts of the Columbia Basin and Pasco Basin where the Hanford Site is located the basalt is underlaiu predominantly by Tertiary continental sedimentary rocks and overlain by late Tertiary and Quaternary fluvial and glaciofluvial deposits. All these were folded and faulted during the Cenozoic to form the current landscape of the region.

Physiographically. the Hanford Site is dominated by the low-relief plains of the Central Plains region and anticlinal nidges of the Yakima Folds region. The physiography of the Columbia Basin is controlled by the late Cenozoic faulting and folding of the CRBG and overlying. sediments of the Ringold Formation. Surface topography in the Columbia Basin has been modified within the past several million years by geomorphic processes related to 1) Pleistocene cataclysmic floods, 2) Holocene eolian activity, and 3) landslides.

Cataclysmic flooding of the Hanford Site occurred when ice dams in western Montana and northern Idaho were breached, allowing large volumes of water to spill across eastem and central Washing1on. The last najor flood occuired about 13,000 years ago, during the late Pleistocene Epoch. Anastomosing flood channe]s, giant current ripples, bergmounds, and giant flood bars are among the landforms created by the floods and are readily seen on the Hanford Site. Most of the large landslides in the region occurred when these floot waters eroded steep slopes of the ridges. The SST farms are located on a major Pleistocene flood bar, the Cold Creek bar. Since the end of the Pleistocene, winds have locally reworked the flood sediments, deporiting sand dunes in the lower elevations and loess (windblown silt) around the masgins of the Pasco Basin. Generally, sand dunes have been stabilized by anchoring vegetation except where the sand dunes have been reactivated where veyetation is disturbed. Localized landslides still occur along the Columbia River a1 the White Bluffs, where itrigation water above the bluffs is rectucing fiction on some of the bedding planes.

\subsubsection{Regional Geology}

The Hanford Site is a small portion of the Columbia Basin, but the geologic record of the site is representative of the geologic history of the Pacific Northwest.

2.1.2.1 Regional Structural Features. The siructure of the Pacific Northwest is controlled by a basement rock assemblage of accreted temanes fused onto the stiucturally conplex Noth American craton by accretion during the early Mesozoic to early Cenozoic. The accieted terranes form the backbone of the Cascade Range. Okanogan Highlands, and the Blue Mountains. The terranes east of the Cascades now are mostly covered by a thick sequence of Cenozoic rocks that were folded and faulted in a noth-south-oriented conpressive regime. North-south compression is continuing today east of the Cascades. and this pattern of Cenozoic deformation is expected to continue into the future.

The Columbia Basin is a structurally and topographically low area surrounded by mountains ranging in age from the late Mesczoic to recent (Figure 2). The Columbia Basin is conposed of two fundamental subprovinces, the Palouse Slope and the Yakima Fold Belt (YFB). The Palouse Slope is a stable, undeformed area overlying the old continental craton that dips westward toward the Hanford Site. The YFB is a series of anticlinal ridges and synclinal valleys in the western and central parts of the Columbia Basin. The edge of the old continental craton lies at 
the junction of these two structural subprovinces and is currently marked by the Ice Harbor dike swarm of the CRBG east of the Hanford Site.

Figure 2. Geologic Setting of the Pasco Basin.

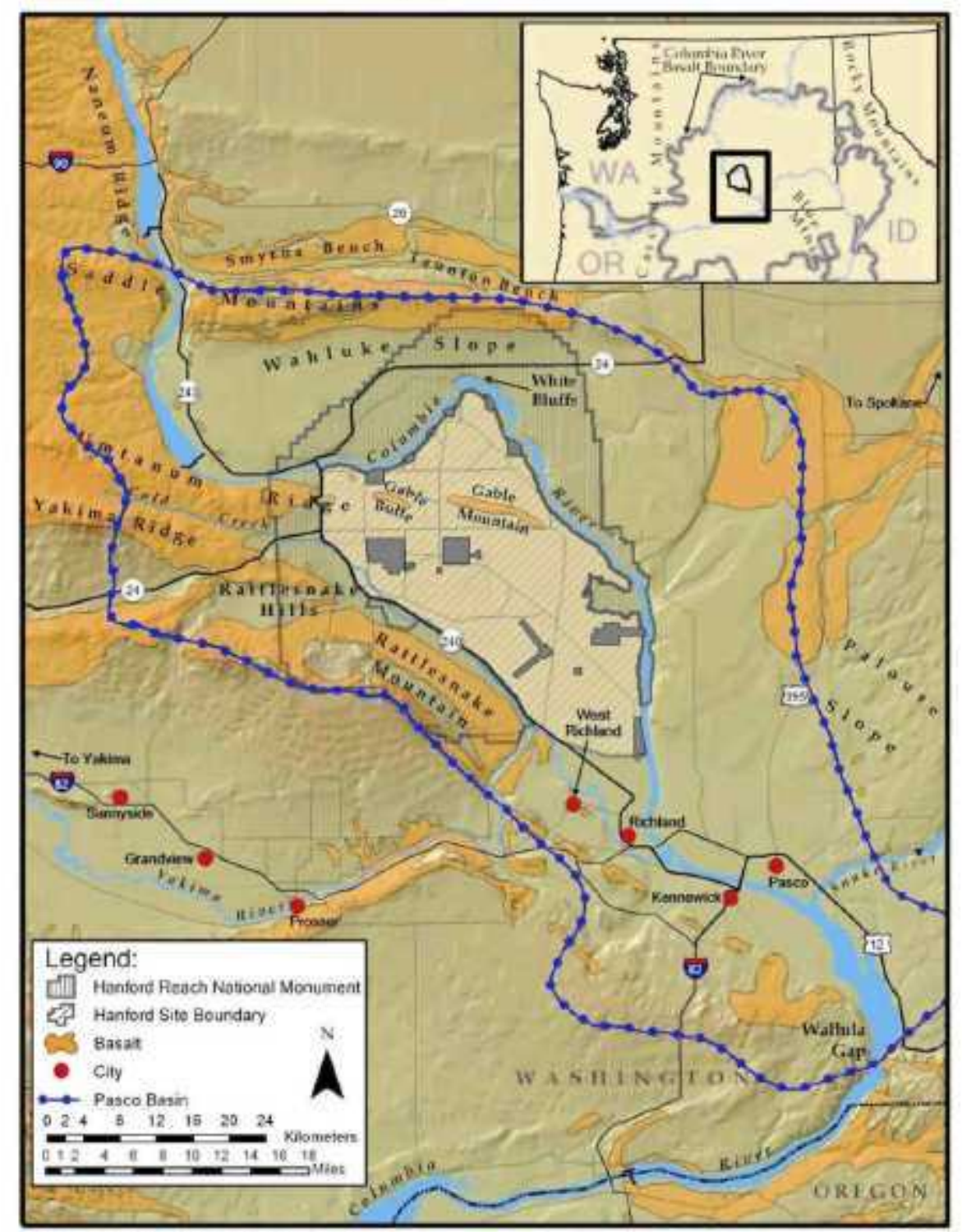

Source: RPP-RPT-46088, Rev. 1.

\subsubsection{Geology and Hydrogeology of the Hanford Site}

2.1.3.1 Hanford Site Stratigraphy. Sediment of the Ringold Formation represents evolutionary stages of the ancestral Columbia River as it was forced to change course across the Columbia Basin by the growth of the YFB. Ringold Formation time began approximately 8.5 million years ago when the Columbia River abandoned Sunnyside Gap and began to flow across the Hanford Site, leaving the Pasco Basin through the present Yakima River water gap along the southwest end of the Rattlesnake Mountain anticline. The northern margin of the 
8.5-million-year-old Ice Harbor basalt controls the Columbia River channel as it exits the Pasco Basin. The first record of the Columbia River at Hanford is in the extensive gravel and interbedded sand of unit A, Ringold Formation member of Wooded Island (Figure 3). The Columbia River was a gravelly braid plain and widespread paleosol system that meandered across the Hanford Site (Fecht et al., 1985, "Paleodrainage of the Columbia River System on the Columbia Plateau of Washington State - A Summary").

Figure 3. Generalized Stratigraphy of the Pasco Basin and Vicinity.

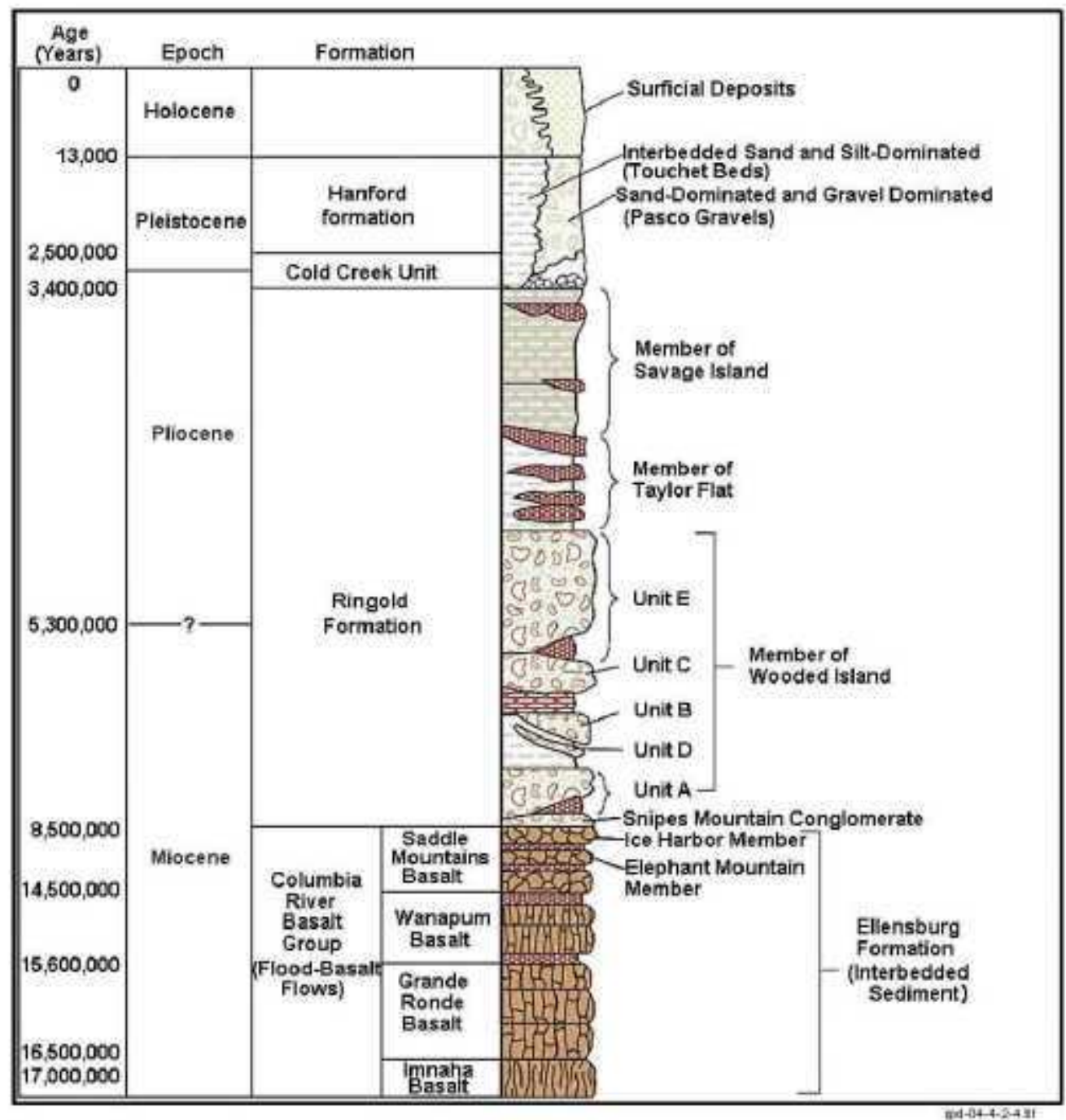

Solirce: RPP-RPT-46088

At about 6.7 million years ago, the Columbia River abandoned the Yakima River water gap along the southeast extension of Rattlesnake Mountain. The main channel of the Columbia River in the Pasco Basin was still through Hanford and the 200 areas. At this time, the Columbia River sediments had changed to a sandy alluvial system with extensive lacustrine and overbank deposits (the lower mud), which was deposited over some of the Hanford Site. The lower mud was then covered by another extensive sequence of fluvial gravels and sands. Unit $\mathrm{E}$ is one of the most extensive Ringold Formation gravels and appears to be continuous under the 200 areas. 
The Columbia River sedimen1s became more sand-dominated about 5 million years ago when over $90 \mathrm{~m}$ (295 feet [fi]) of interbedded fluvial sand and overbank deposits accumulated at Hauford. These deposits are collectively called the Ringold Formation member of Taylor Flat (BHI-00184, Miocene- to Pliocene-Aged Suprabasalt Sediments of the Hanford Site, South-Central Washingion). The fluvial sands of the member of Taylor Flat dominate the lower cliff's of the White Bluffs. Between 4.8 million years ago to the end of Ringold time at 3.4 million years ago, lacustrine deposits dominated Ringold Formation deposition. A series of three successive lakes is recognized along the White Bluffs and elsewhere along the margin of the Pasco Basin (BHI-00184). The lakes probably resulted from damming of the Columbia River farther downstream. possibly near the Columbia Gorge. The lacustrine and related deposits in the Pasco Basin are collectively called the Ringold Formation member of Savage Island. At the end of Ringold tine, western Noth America underwent regional uplift. resulting in a change in base level for the Columbia River system. Uplift caused a change from sediment deposition to regional incision and sediment removal. Regional incision is especially apparent in the Pasco Basin, where nearly $100 \mathrm{~m}$ (328 ft) of Ringold Formation sediment has been removed from the Hanford area. The regional incision marks the beginning of Cold Creek time and the end of major deposition by the Columbia River.

In the Pasco Basin, the Cold Creek unit reoords most of the geologic events between the incision by the Columbia River and the next major event, the Missoula floods. The older Ringold Formation surface at the 200 West Area was exposed to weathering, resulting in the formation of a soil horizon on its surface. Because the climate was becoming arid, the resulting soil became a pedogenically altered. carbonate-rich, cemented paleosol. The development of this carbonate-rich paleosol is much greater in the 200 West Area than in the 200 East Area due to longer exposure of the surface. This ancient paleosol is referred to as the lower Cold Creek unit (CCUI) subunit. Concurtently. eolian sediments and minor fine-graiued flond deposits from streams criginating from the nearby nddges were deposited on the paleosol. resulting in a wide variety of sediments that are called the upper subunit of the Cold Creek unit (CCUu). Because of the long time interval (approximately 3.4 to 2 million years ago), several localized paleosols like the lower Cold Creek unit were able to develop in the upper Cold Creek unit. Throughoul Cold Creek time. streanis from the Rattlesuake. Yakima. and Umtanum Ridges were carving channels to the Cold Creek drainage. depositing basaltic gravels in their stream beds. These form the side-stream alluvial facies of the Cold Creek unit.

During the Pleistocene, cataclysmic floods inundated the Pasco Basin several times when ice dams failed in nothern Washington (Baker et al. 1991, "Quatemary Geology of the Columbia Plaleau"). Current interpretations suggest as many as 40 flooding events occurred as ice dams holding back glacial Lake Missoula repeatedly formed and broke. In addition to larger major flood episodes, there were probably numerous smaller individual flood events. The sediment deposited by the cataclysmic flood waters has been informally called the Hanford formation because the best exposures and most complete deposits are found there. The coarse-grained (or gravel-dominated) floot facies is generally contined to relatively narrow tracts within or near flood channel-ways. The plante-laminated sand facies (sand-dominated) occurs as a broad sheet over most of the central basin. Paleocuitent indicators within beds of plane-laminated sands are unidirectional, generally toward the south and east within the Pasco Basin. 
Since the end of the Pleistocene, the main geologic process has been wind. After the last Missoula flood drained from the Pasco Basin, winds moved the loose, unconsolidated material until vegetation was able to stabilize it. Stabilized sand dunes cover much of the Pasco Basin. but there are areas. such as along the Hanford Reach National Monument. where sand dunes remain active.

2.1.3.2 Hydrogeology of the Hauford Site. The vadose zone is host to the underground storage tanks and related facilities across Hanford. The hydrostatigraphy of the vadose zone forms the basis with which to interpret and extrapolate the physical and gecthemical properties that control the migration contaminants from the past releases in the tank farms. Of particular interest are the hydrophysical property contrasts between the coarser-grained and finer-grained facies. The contrast appears to have a strong influence on the distribution of leaks, associated with a pheuonenon called moisture dependent anisotropy (Yeb e1 al., 1985, "Stochastic Analysis of Unsaturated Flow in Heterogeneous Soils. 3: Observations and Applications" and Ward et al.. 2006, "Upscaling Unsaturated Hydraulic Parameters for Flow Through Heterogeneous Anisotropic Sedimeuts").

Aquifers at the Hanford Site are divided into 1) confined and 2) suprabasalt or unconfined aquifer systems. The Jegional. confined aipuifer system occurs within the CRBG and extends from western Idaho through eastern Washington and northeastern Oregon (Lindsey, 2009. "Geologic Features in the Columbia River Basalt Groupe CRBG) Aquifer System that Form Vertical Flow Pathways and Subdivide the Regional Groundwater Flow System: Examples from the Columbia Basin Ground Water Management Area (GWMA) of South-Central Washington ${ }^{11}$ ). The unconfined aquifer system ocurs within fluvial, glaciotluvial, and lacustrine sediments deposited on top of the CRBG. The general direction of groundwater flow in the unconfined aquifer is primarily from uatural recharge areas on the basalt ridges west of the Hanford Site to discharge along the Columbia River. The flow was interupted locally by artificial groundwater mounds that developed in the unconfined aquifer in the 200 Areas due to discharge from liquid waste disposal operations (Gray et al., 1989. "Environmental Monitoring at Hanford, Washing(on, USA: A Brief Site History and Summary of Recent Results"). Since cessation of the discharges, the water table has declined in the 200 East Area and flow directions are returning to pre-Hanford Site directions wward the east.

\subsection{TANK FARM DESCRIPTIONS}

\subsubsection{A/AX Tank Farms}

The 241-A and -AX tank farms are located on the eastem edge of the 200 East Area. The SSTs in the tank farms historically received mixed and high-level radioactive waste. The tank fains have been out of service since 1980 , but continue to store significant quantities of waste.

The A tank farm contains six SSTs, constructed in 1955, each with one-million gallon (gal) (3.7 $\times 10^{6}$ liter [L]) capacity. The tanks are $75 \mathrm{ft}(23 \mathrm{~m})$ in diameter, located approximately $6 \mathrm{ft}$ ( $2 \mathrm{~m}$ ) below ground surface (bgs), and extend to approximately $50 \mathrm{ft}(15 \mathrm{~m}$ ) bgs. Of the six tanks in A farm, three are classified as assuned leakers (HNF-EP-0182-280, Waste Tank Summary for the Month Ending July 31, 2011). recent work (RPP-ASMT-42278.

Tank 241 A-103 Leak Assessment Report) has recommended that tank 241-A-103 be reclassified 
as sound. The AX tank farm contains four SSTs, constructed in 1963, each with one-million gallon $\left(3.7 \times 10^{6}\right.$-L) capacity. The tank constiuction and sizes are similar to A farm. The AX tank farm received PUREX acid waste from years 1965 through 1969 (RPP-35484. Field Investigation Report of Waste Managenent Areas $C$ and $A-A X$ ).

\subsubsection{B/BX/B Y Tank Farms}

The B, BX, and BY tank farms are SST farms on the Hanford Site that form waste management area (WMA) B-BX-BY (referred to as B Complex). The B Complex is located in the northern portion of the 200 East Area and includes a number of cribs and trenches on the west, north, and northeast sides. Most of the cribs and trenches received waste directly from the B and U Plants (WHC-SD-WM-ER-575. Liquid Radioactive Waste Discharges from B-Plant to Crib).

The $\mathrm{B}$ Complex consists of the following tank farm facilities:

- B tank farm

- Twelvel00-series SSTs of 530,000-gal (2 \& $10^{6}$-L) capacity

- $\quad$ Four 200 -series SSTs of 55,000 -gal $\left(0.21 \times 10^{6}\right.$-L) capacity

- BX tank farm

- Twelve 100 -series SSTs of 530.000 -gal $\left(2 \times 10^{6}\right.$-L $)$ capacity

- BY tank farm

- Twelve 100 -series SSTs of 758,000 -gal $\left(2.9 \times 10^{6}\right.$-L) capacity

- Leak detection systems

- Tank ancillary equipment.

The 100 -series SSTs are $75 \mathrm{ft}(23 \mathrm{~m})$ in diameter. The four 200 -series SSTs in B Farm are $20 \mathrm{ft}$ $(6.1 \mathrm{~m})$ in diameter. The B and BX SSTs are approximately $30 \mathrm{ft}(9 \mathrm{~m})$ tall from base to done. The smaller SSTs are approximately $26 \mathrm{ft}(8 \mathrm{~m})$ tall. Twenty of the 40 SSTs in the B Complex are currently designated as confirmed or assumed leaking tanks in HNF-EP-0182-280.

\section{2 .3 C Tank Farm}

C farm is located in the Central Plateau, near the eastern edge of the 200 East Area. It was one of the first tank farms built, between 1944 and 1945. The tank farm contains twelve 100-series tanks. four 200-series tanks. and one 300-series calch tank. The 100 -series tanks are $23 \mathrm{~m}$ (75 ft) in diameter, have a 5-m (15-ft) operating depth, and have an operating capacity of 530,000 gallons $\left(2 \times 10^{\circ}\right.$-L) each. The 200 -series tanks are $6 \mathrm{~m}(20 \mathrm{ft})$ in diameter with a 7.32-n (24-ft) operating depth and an operating capacity of 55.000 gallons $\left(0.21 \times 10^{6}\right.$-L) each. The C-301 catch tank has a capacity of 36,000 gallons $\left(0.14 \times 10^{6}\right.$-L). Only tanks $241-\mathrm{C}-101$ (C-101) through 241-C-106 (C-106) have concrete pits. The other 100-series tanks are equipped with centrally located salt well pump pits. The tanks sit below grade with at least $2 \mathrm{~m}$ ( $7 \mathrm{ft}$ ) of soil 
cover to provide shielding from radiation exposure to operating personnel. Tank pits are located on top of the tanks and provide access to the tank, pumps, and monitoring equipment.

To support the transfer and storage of waste within WMA C SSTs. there is a complex waste transfer system of pipelines (transfer lines), diversion boxes, waults, valve pits. and other miscellaneous structures.

Twelve UPRs have occurred within or near C farm (RPP-PLAN-39114, Phase 2 RCRA Faciliry Investigation/Corrective Measures Study Work Plan for Waste Management Area C). The largest ones are associated with leaks in pipelines or diversion boxes. from inlet/outlet ports of the SSTs, or with leaks from the SSTs themselves. RPP-PLAN-39114 provides more detail on these UPR sites. Six planned releases have also occured within the tauk farm. which include a septic discharge. drywells, and a French drain. Figure I shows the approximate location of all planned and unplanned releases.

Five tanks (C-103. C-201, C-202, C-203, and C-204) have been retrieved to meet the requirements of the Hanford Federal Facility Agreement and Consent Order (HFFACO). Tank $\mathrm{C}-106$ also has been retrieved, but is undergoing a HFFACO Appendix $\mathrm{H}$ waiver request as its residual waste volune is slightly above the HFFACO limit. Tanks C-108, C-109, and C-110 are currently retrieved to the limit of modified sluicing technology with firther retrieval on hold. Activities related to waste retrieval at tanks C-104 and C-111 have been stated. Preparations are underway to initiate waste retrieval at tank C.-107 using the Mobile Arm Retrieval System (MARS).

\subsubsection{T/TX/TY Tank Farms}

The $T$ tank farm is in the northern portion of the 200 West Area near the T Plant and is surrounded by a number of cribs and trenches used for planned releases. Most of the cribs and all of the trenches recejved waste diretly from SSTs. Refer to WHC-MR-0227, Tank Wastes Discharged Directly to the Soil at the Hanford Site.

Washington Rjver Protection Solutions, LLC (WRPS) has responsibility for vadose zone characterization at the tank farms under the direction of the U.S. Department of Energy (DOE), Office of River Protection. The following documents provide background on T. TX. and TY tank farm vadose zone characterization projects:

- $\quad$ RPP-23752, 2005, Field Investigation Report for Waste Management Areas $T$ and $T X . T X$, Revision 0-A.

- $\quad$ RPP-7578, 2002, Site-Specific SST Phase 1 RFI/CMS Work Plan Addendum for WMAs $T$ and $T X-T Y$, Revision 2.

The T tank farm consists of the following:

- $\quad 12100$-series SSTs

- 4200 -series SSTs

- Waste transter lines

- Leak detection systens

- Tank ancillary equipment. 
The 100 -series SSTs are $23 \mathrm{~m}$ or $75 \mathrm{ft}(23 \mathrm{~m}$ or $75 \mathrm{ft}$ ) in diameter. The four 200 -series SSTs are $6.1 \mathrm{~m}(20 \mathrm{ft}$ ) in diameter. The 12 larger SSTs are approximately $9 \mathrm{~m}$ (30 ft) tall from base to dome. The snaller SSTs are approxinately $8 \mathrm{~m}(26 \mathrm{ft})$ tall. Seven of the 16 SSTs in T tank farm are designated as assumed leakers (HNF-EP-0182-280).

The TX and TY tank farms (referred to as the TX-TY Complex) are two of 12 SSTs farms on the Hauford Site that forn WMA TX-TY. The TX-TY Complex also includes a number of cribs and trenches located mainly to the west, southeast, and uortheast of the tank farms. The TX-TY Complex facilities recejved a variety of waste streams generaled primarily during bismuth phosphate plutonium separations operations at $T$ Plant and uranium recovery operations at U Plant (RPP-5957, Historical Vadose Zone Contamination from $T$, $T X$, and TY Tank Farm Operations).

The TX-TY Complex contains the following tank tarm facilities:

- TX tank farm - 18100 -series SSTs with 758,000-gal $\left(2.9 \times 10^{6}\right.$-L) capacity

- TY tank farm - 6100 -series SSTs with 758,000 -gal $\left(2.9 \times 10^{6}\right.$-L) capacity

- Leak detection systems

- Tank ancillary equipment.

The 100-series SSTs are $75 \mathrm{ft}(23 \mathrm{~m})$ in diameter and approximately $37 \mathrm{ft}(11 \mathrm{~m})$ tall from base to dome. Thitteen of the 24SSTs in the TX-TY Complex are currently designated as tanks that have been confitmed or assumed to have leaked in HNF-EP-0182-280. Reassessment of many of the TY tanks has been recommended (RPP-RPT-42296. Hanford TY-Farm Leak Assessments Report). A reassessment of TX tanks is in progress.

\subsubsection{S/SX Tank Farms}

The S and SX tank farms were constructed to store high-level radioactive waste generated by chemical processing of irradiated uranium tuel. The $S$ tank farm contains 12 SSTs and is located in the southwest portion of the 200 West Area, northwest of S Plant. The site is sulrounded by a number of cribs and trenches. Most of the cribs and all of the trenches received wastes directly from SSTs (WHC-MR-0227).

The $S$ tank farm comprises the following:

- $\quad 12$ SSTs with 758,000 -gallon $\left(2.9 \times 10^{6}\right.$-L) capacity

- Waste transter lines

- Leak detection system

- Tank ancillary equipment.

The SX tank farm contains 15 SSTs and is directly south of S tank farm. The SX tank farm comprises the following:

- 15 SSTs with $1,000,000$-gallon $\left(3.7 \times 10^{6}\right.$-L $)$ capacity

- Waste transfer lines

- Leak detection systems

- Tank ancillary equipment. 
The S and SX tank farms were constructed in the 1950s to support operations at the REDOX Plant, which operated fiom 1952 through 1967. The S tank farm contains 1welve 100-Series SSTs that were constructed between 1950 and 1951 and put into service in 1951. The SX tank farm contains fifteen 100-Series SSTs that were constructed between 1953 and 1954 and put into service in 1954. The two tank farms were used to store and transfer waste until the late $1970 \mathrm{~s}$ and early 1980s.

Ten of the 15 SSTs in the SX tank farm and one of the 12 SSTs in S tank farm are classified as assumed leakers, however, RPP-ASMT-47140. Tank 241-SX-110 Leak Assessment Repont recommended that tanks $\mathrm{SX}-110$ and $\mathrm{SX}-104$ be reclassified as sound. In addition. RPP-RPT-48589, Hanford 24l.S Farm Leak Assessment Repont has recommended that tank S-104 be reassessed and indicates that releases were likely from a spare nozzle that overflowed when the tank was overfilled.

\subsubsection{U Tank Farm}

$\mathrm{U}$ tank farm is located iu the central portion of 200 West Area of the Hanford Site. U tank farm contains twelve, 100-Series SSTs and four, 200-Series SSTs that were constiucted from 1943 through 1944. put into service in 1946 , and are currently out of service and are pending final waste retrieval actions. Because of its long operational history, the $\mathrm{U}$ tank farm received waste generated by essentially all of the Hanford Site's major chemical processing operations including bismuth phosphate fuel processing, uranium recovery. PUREX fuel processing, and fission product recovery (RPP-15808. Subsutface Conditions Description of the U Waste Management Area). Information on the geology and hydrology of the $\mathrm{U}$ tank farm area can be found in RPP-23748, Geology, Hydrogeology, Geochemisty, and Mineralogy Data Package for the Sintgle-Shell Tank Waste Management Areas at the Hanford Site.

The U tank farm comprises the following:

- Twelve 100 -Series SSTs with a 530,000-gal $\left(2.0 \times 10^{6}\right.$-L) capacity

- Four 200-Series SSTs with a 55,000-gal $\left(0.21 \times 10^{6}\right.$-L) capacity

- Waste transter lines

- Leak detection systens

- Tank ancillary equipnent.

The 100 -Series tanks are $75 \mathrm{ft}(22.9 \mathrm{~m})$ in diameter and $30 \mathrm{ft}(9.1 \mathrm{~m})$ tall. The tanks have a $15 \mathrm{ft}$ (4.6 meter) operating depth. The 200 -Series tanks are $20 \mathrm{ft}(6.1 \mathrm{~m})$ in diameter and $37 \mathrm{ft}$ $(11.3 \mathrm{~m})$ tall from base to dome. The tanks have a $24-\mathrm{ft}$ ( 7.3 meter) operating depth.

The tanks in the $U$ farm contain an estimated total volume of $2,998,000$ gal $\left(11.3 \times 10^{6}\right.$.L) of mixed wastes consisting of various bismuth phosphate. REDOX. and PUREX processing waste streams (HNF-EP-0182-280). General tank content (i.e., licuid and solid volumes) data and some tank monitoring data are summarized monthly in waste tank summary reports ie.g., HNF-EP-01 82-280). Tanks U-101, U-104, U-110, and U-112 are classified as leakers. These tanks are currently estimated to have leaked a total of 98,500 to 101,600 gal $(373,000$ to 385,000-L) of waste. Leak inventory reassessments for these tanks are in progress. Except for a liquid level decrease. there is no indication of a release from tank U-101 (RPP-35484). 


\subsection{ELECTRICAL RESISTIVITY DESCRIPTION}

Geophysics is a science where physical eath properties are neasured, with the goal of using those properties to help explain geologically- or hydrogeologically-related phenomena. Geophysics, for example, can be used to remotely observe changes in hydrogeological properties or to extend or "ground truth" information about geochemical conditions based on borehole data. Field geophysical surveys are most reliable as a first-order target recognition tool. In this mode. sufficient background data are needed to distinguish the entirety of the target and confirm the extent of its edges. A target will not be identified if the variations in properties of the background material are similar in contrast and scale to those associated with the target. Assuming that targets can be identified, the next order of interpretation is the relative degree of each target's size and intensity. A fair comparison can only be conducled if the survey parameters, e.g. sensor placement, data density, etc.. are consistent across the nultiple targets. as the sensitivity and resolution of gecphysical methods are affected by these parameters. Lastly, if the targets can be differentiated, then it may be possible to build field-scale correlations to other parameters of interest, such as moisture content, contaminant concentration, or specific geologic strata. Regression models can be developed if the cotrelation is high. The spatial distribution of resistivity can then be converted to the unknown hydrogeological parameter. This last mode of analysis is an active area of research for a multitude of geophysical techniques (e.g. Moysey and Knight, 2004, "Moteling the Field-Scale Relationship Belween Dielectric Constant and Water Coutent in Heterogeneous Systems" and Singha and Gorelick, 2006, "Effects of Spatially Variable Resolution on Field-Scale Estimates of Tracer Concentration from Electrical Iuversions Using Archie's Law").

One of earth's physical properties commonly exploited in geophysical deployments at the Hanford Site is the ability for electrical current to flow in the subsurface. This is the basis for electrical resistivity measurements ( $\mathrm{SGE}$ ), where a volumetric measurement of the resistance to electrical current flow within a medium is acquired (Rucker. et al.. 2011. "Electrical Resistivity In Support Of Geological Mapping Along the Panama Canal" and Telford et al., 1990, Applied Geophysics). Direct electrical current is propagated in rocks and minerals by electronic or electrolytic means. Electronic conduction occurs in minerals where free electrous are ayailable, such as the electrical cument flow through metal. Electrolytic conduction. on the other hand, relies on the dissociation of ionic species within a pore space and is more common in the partially saturated sandy, silty, and grayelly soils encountered at Hanford. With electrolytic conduction, the movement of electrous varies with the mobility, conceutration, and the degree of dissociation of the ions. Soil free from past discharge activities can be expected to have high resistivity values. given the relative low natural saturation and low jonic strength of the porewater. Near contaminant discharge points, the measured resistivity will decrease depending on the transport mechanisms of the various ionic constituents. For example, nitrate (an anion) was released in large quantities, up to $22 \times 10^{3}$ metric tons at the BC cribs and trenches (BCCT) site, and has a partition coefficient $\left(k_{d}\right)$ near zero. The low $k_{d}$ of this anion allows it to migrate virtually unimpeded through the vadose zone and nitrate plumes typically show large low resistivity signatures. On the other hand, cesium (a cation and gamma ray emitter) was released in snall quantities ionically, and has a much higher pattition coefficient that causes it to patially sorb onto the Hanford sediments (Zachara et al., 2007 and Steefel et al.. 2003. "Cesium Migration In Hanford Sediment: A Multisite Cation Exchange Model Based on Laboratory 
Transport Experiments"). The cesium-based salts, therefore, do not have a signature much different than the expected background resistivity conditions. However, other methods such as spectral gamma borehole logging, which are well suited for mapping immobile gamma constituents, can complement the resistivity method to form a more complete picture for the distribution of most contamination across the site.

Mechanistically, the resistivity method uses electric current (I) that is transmitted into the earth through one pair of electrodes (transmitting dipole) that are in contact with the soil. The resultant voltage potential (V) is then measured across another pair of electrodes (receiving dipole). Numerous electrodes can be deployed along a transect (which may be anywhere from meters to kilometers in length), or within a grid, and Figure 4 displays examples of electrode layouts for surveying. Figure 4A displays transects with a variety of array types (dipole-dipole [DD], Schlumberger, pole-pole [PP]). A complete set of measurements is when each electrode (or adjacent electrode pair) has a turn at passing current, while all other adjacent electrode pairs are used for voltage measurements. Modern equipment is used to automatically switch the transmitting and receiving electrode pairs through a single multi-core cable connection.

Figure $4 \mathrm{~B}$ displays a grid of electrodes on the surface and buried within boreholes to any depth. The grid array of electrodes provides more data and increased sensitivity of the measurement technique, but costs more in terms of equipment and time. Although the figure conceptually shows a neat arrangement of rows and columns of electrodes, a true $3 \mathrm{D}$ survey can have a completely random distribution of electrodes anywhere within the block of earth being imaged. Figure $4 \mathrm{~B}$ also illustrates that a long electrode (e.g., existing steel-cased well) could also be used as an electrode anywhere within the grid as long as it is electrically coupled with the earth. Rucker et al., 2009 describes in more detail the methodology for efficiently conducting a 3D electrical resistivity survey.

\section{Figure 4. Layout of Electrodes for Conducting Electrical Resistivity Characterization}

\section{A} B
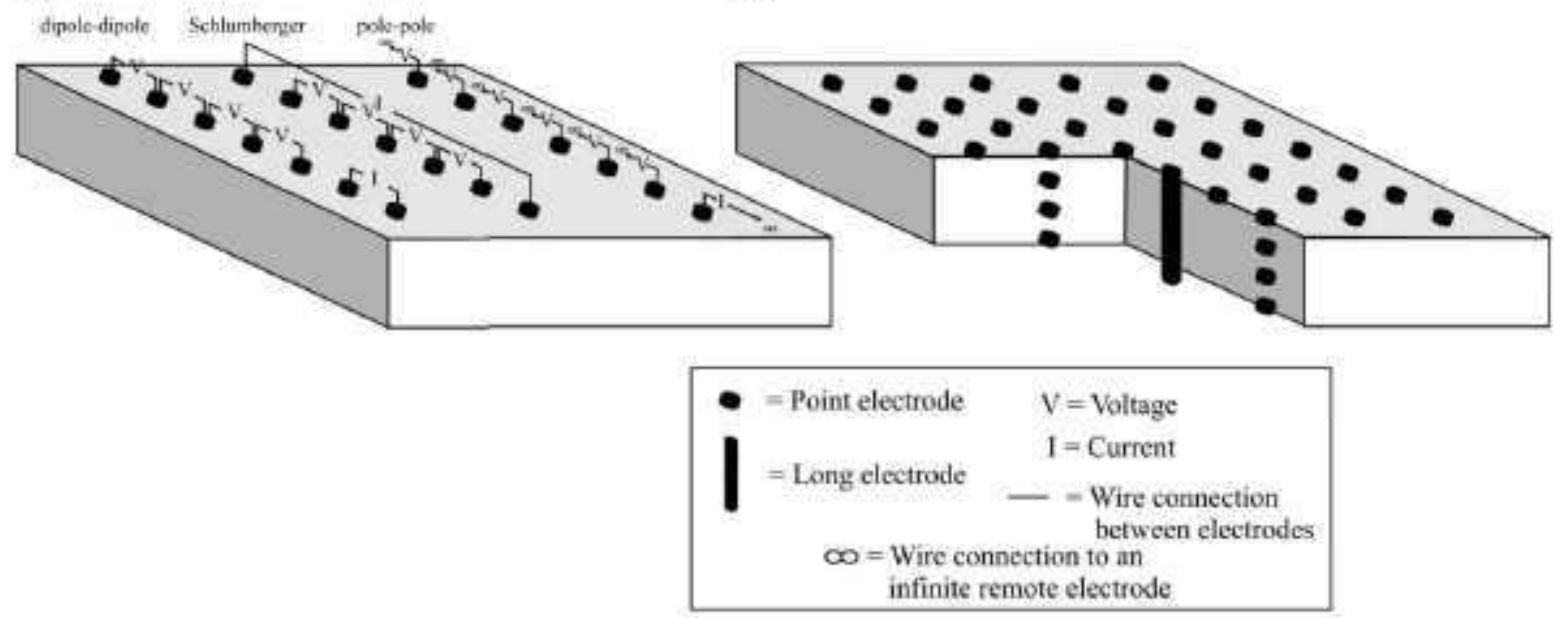

A) Atray types for acquiring resistivity data along transects. B) A grid of electrodes on the surface and within boreholes that can be used to enhance the imaging of a block of earth.

The modern application of the resistivity method uses numerical modeling and inversion theory to estimate the electrical resistivity distribution of the subsurface given the known quantities of 
electrical current, measured voltage, and electrode positions. Older methods of processing resistivity data can be found in Telford et al.,1990, and significant progress has been made within the past 15 years at Hanford and else where. A common resistivity inverse method incorporated in commercially available codes is the regularized least squares optimization method (Sasaki, 1989, "Two-Dimensional Joint Inversion of Magnetotelluric and Dipole-Dipole Resistivity Data" and Loke et al.. 2003, "A Comparison Of Smooth And Blocky Inversion Methods in 2D Electrical Inaging Surveys"). The objective function within the optimization aims to ninimize the difference between measured and modeled voltage potentials (subject to certain constraints) and the optimization is conducted iteratively due to the nonlinear nature of the model that describes the potential distribution. The relationship between the subsurface resistivity $(\rho)$ and the neasured voltage is given by the following equation (Dey and Motrison, 1979, "Resistivity Modeling For Arbitrarily Shaped Three-Dinensional Stuctures"):

$$
-\nabla \cdot\left[\frac{1}{\rho(x, y, z)} \nabla V(x, y, z)\right]=\left(\frac{1}{U}\right) \delta\left(x-x_{z}\right) \delta\left(y-y_{s}\right) \delta\left(z-z_{z}\right)
$$

where $\mathrm{I}$ is the current applied over an elemental volume $\mathrm{U}$ specified at a point $\left(\mathrm{x}_{3} . \mathrm{y}_{5}, \mathrm{z}_{5}\right)$ by the Dirac delta function.

Eijuation (1) is solved many times over the volume of the earth by iteratively updating the resistivity model values usiug either the L2-norm smoothuess-cousirained least squares nethod, which aims to minimize the square of the misfit between the measured and modeled data (deGroot-Heslin and Constable. 1990. "Occam's Inversion to Generate Smoth, Two-Dimensional Models from Magnetotelluric Data" and Ellis and Oldenburg. 1994, "Applied Geophysical Inversion"):

$$
\left(J_{i}^{\mathrm{T}} J_{1}+\lambda_{1} W^{T} W\right) \Delta_{i}=J_{1}^{T} g_{1}-\lambda_{1} W^{T} W_{i-1}
$$

or the L1-norm that minimizes the sum of the absolute value of the misfit:

$$
\left(J_{i}^{\mathrm{T}} R_{d} J_{i}+\lambda_{i} W^{\mathrm{T}} R_{m} W\right) \Delta_{i}=J_{1}^{\mathrm{T}} R_{\mathrm{a}} g_{i}-\lambda_{1} W^{\mathrm{T}} R_{\mathrm{r}} W_{i-1}
$$

where $\mathrm{g}$ is the data misfit vector containing the difference between the measured and modeled data. $J$ is the Jacobian matrix of partial derivatives, $W$ is a roughness filter, $R_{d}$ and $R_{10}$ are the weighting matrices to equate model misfit and model roughness, $\alpha R_{i}$ is the change in model parameters for the $i^{\text {th }}$ iteration, $r_{i}$ is the motel parameters for the previous iteration, and $\sigma_{i}=$ the damping factor. The same inversion procedure is applied for both point and long electrodes (Rucker et al.. 2010). The difference, however. is how the electrodes are accommodated in the forward model.

\subsection{ELECTRICAL RESISTIVITY IN INDUSTRIALIZED AREAS}

Industrialized facilities, such as fuel depots. refineries, and power plants may have physical or administrative access restrictions that polentially restrict sampling. One of the greatest challenges within these sites is associated with infrastructure (buildings, tanks, piping, fences, power lines, etc.), which limits the ability to fully characterize the soil and groundwater beneath the areas of concern. The infrastructure can be located above or below ground, and is typically metallic and pervasive, impeding many invasive techniques that need direct contact with the soil. 
Access to soil beneath a building or suspected leaking storage tank may be very difficult if these facilities are large. The SSTs and associated piping at Hanford nake finding adequate sampling locations difficult. Technologies such as directional drilling shown in Khaleel et al., 2007. "Impact Assessment of Existing Vadose Zone Contamination al the Hanford Site SX Tank Farm:" "direct push" in McKinley et al., 2006, "Microscale Controls on the Fate of Contaminant Uranium in the Vadose Zone. Hanford Site. Washington;" and Lm et al., 2010, "Characterization of Uranium-Contaninated Sediments From Beneath a Nuclear Waste Storage Tank Fron Hauford. Washington: Implications for Contaminant Transport and Fate" have been used to characterize the lank farms, but locations for placement of boreholes is limited to the few open areas without subsurface obstructions.

Unlike borehole methods, which rely on drilling and sampling within a very localized area, geophysical methods have the ability to characterize the subsurface at locations fas from the sensor location. The trade-off is that many sensors must be deployed around the study area in order to eapture the full extent of the contamination. Sogade et al., 2006. "Induced-Polarization Detection and Mapping Of Contaminant Plumes:". Cardarelli and Di Filippo, 2009, "Electrical Resistivity and Induced Polarization Tonngraphy in Identifying the Plume of Chlorinated Hydrocarbons in Sedimentary Formation: A Case Study in Rho (Milan, Italy):" and Rucker et al. 2009 all show that the electrical resistivity or induced polanization methods can be used to image a broad swath of the ground for contaminant plume mapping. However, hundreds or thousands of electrodes nay be needed for the measurenent campaign. Rucker et al., 2009 lists several studies over the past 15 years showing how the electrical resistivity method in particular is expanding in scale as both acquisition hardware and processing software become more robust.

Electrical resistivity does not require direct coutact with a potential source of contanination to be an effective mapping tool; however. direct contact can enhance the mapping capabilities, when available. The use of resistivity methods can be hindered in industrialized areas and tank farms due to material property interferences posed by infrastructure. Metallic pipes, tanks, and fences have much lower resistivity values than the subsurface targets, contributing to the inftrastructure effectively absorbing the electrical signal (Vickery and Hobbs. 2002, "The Effect of Subsulface Pipes on Apparent-Resistivity Measurements"). The material contrasts between the clean soil of high resistivity and contaminated soil of moderately low resistivity will be overwbelmed by the extremely low values of the metal. Potential methods to overcome these hindrances include: 1) interpreting underlying features with the full knowledge that the infiastructure exists ouly in small portions of the data (e.g., Udphuay et al., 2011, "Three-Dimensional Resistivity Tomography in Extreme Coastal Terrain Amidst Dense Cultural Signals: Application to Cliff Stability Assessment at the Historic D-Day Site"); 2) post processing and filtering the resistivity data to renove the effects of infrastructure indirectly (e.g., Vickery and Hobbs, 2002); or 3) taking advantage of the sile's infrastucture by incorporating the buried metal as electrodes (e.g., Daily et al.. 2004. "Low-Cost Reservoir Tomographs of Electrical Resistivity"). The latter has been shown to be a promising method for characterization and monitoring of SSTs.

The steel-cased monitoring wells that suround the storage tanks, originally installed for borehole logging, have been used as electrodes to track historical leaks (Rucker and Fink. 2007, "Inorganic Plume Delineation using Sulface High Resolution Electrical Resistivity at the BC Cribs and Trenches Site, Hanford," Glaser et al., 2008, A Summary of Recem Geophysicat Investigations at the Department of Energy Hanford Nuclear Facility; Rucker et al., 2010; and 
Calendine et al., 2011, "Automated Leak Delection of Buried Tanks using Geophysical Methods at the Hanford Nuclear Site"). This method has been referred to as long electrode electrical resistivity tomography (LE-ERT) iu (Ramirez et al.. 2003, "Monitoring Carbon Dioxide Floods Using Electrical Resistance Tomography (ERT): Sensitjvity Studjes ${ }^{11}$ ).

\subsection{VALIDATION OF THE LONG ELECTRODE METHOD}

Validation of the LE-ERT method, or any contiguration of the electrical resistivity method for that matter, is difficult to conduct because subsurface conditions are only known in highly controlled settings. Past validation efforts for hydrogeophysical imaging can be grouped generally into: 1) molel validation; 2) validation through conirolled laboratory experimentation; and 3) validation through field sampling.

A more complete knowledge of the subsulface for field validation can only be achieved through destructive post-survey analyses of the soil or by burying a taset composed of an amended soil of known concentration. The amended soil methot for field validation of the LE-ERT methos was applied to gain insight into its ability to reconstruct a known static target. Although the target properties were well known, an exhaustive measure of the sutrounding soil was not conducted. Instead, a few representative samples were taken of the excavated soil to make generalizations about the background conditions. The arrangement of the long electrodes was designed to replicate a $1 / 17$ scaled mock-up of a tank farm. The target was constructed by hand to simulate a saline contaminant plume using two soils of known properties and dinensions. The electrical resistivity measurement campaign iucluded a combination of sufface, long, and a few buried point electrodes. similar to the survey designs described in (RPP-RPT-49129. ThreeDimensional Suface Geophysical Exploration of the BY Tank Farm. Image reconstruction from the distributed point electrodes on the surface and buried in the survey domain was considered as a standard for which to make comparisons with LE-ERT.

A pilot-scale field validation of the LE-ERT method was conducted to demonstrate the resolution capabilities for targets at the Hanford site in central Washington. The Hanford site is home to a large number of underground storage tanks, grouped into tank farms, some of which may have leaked a substautial volume of contamination to the vadose zone. Additionally, direct disposal of waste occuired to the ground in nearby unlined trenches. sunken vaults ireferred to as cribs). ponds. reverse wells, etc. Understanding the degree to which the soil and groundwater have been impacted is difficult because the site is highly industrialized, limiting both direct (drilling and sampling) and indirect (geophysical characterization) methodologies.

\subsubsection{Experimental Site}

The pilot-scale field validation was conducted within the top two meters of soil in an open field west of the Pacific Northwest National Laboratory (PNNL). approximately $30 \mathrm{~km}$ south of the tank farms. Soil conditions at the experimental site are very similar to the storage tank region, due to the large cataclysmic flooding and associated sediment deposition from the glacial Lake Missoula floods (see coverage maps in Baker and Bunker, 1985, "Cataclysmic Late Pleistocene Flooding from Glacial Lake Missoula: A Review" and Bjornstad et al, 2001, "Long History of Pre-Wisconsin, Ice Age Cataclysmic Floods: Evidence from Southeastern Washington State"). Figure 5A shows the experimental site location as well as the location of the Hanford tank farms 
distributed in 200 east and 200 west. In general, the near surface soil consists of reworked Hanford formation, a predominantly unconsolidated group of sediments that cover a wide range of grain size, from sand to silt, and sorting, (PNNL-16887, Geologic Descriptions for the Solid-Waste Low Level Burial Grounds). Since the end of the Pleistocene, winds have deposited dune sands and loess sediments (WHC-MR-0391. Field Trip Guide to the Hanford Site) in the region. The dunes are stabilized by anchoring vegetation, including grasses, forbs, and sage brush. At the experimental site, only a few grasses were present.

Figure 5. Site Location.
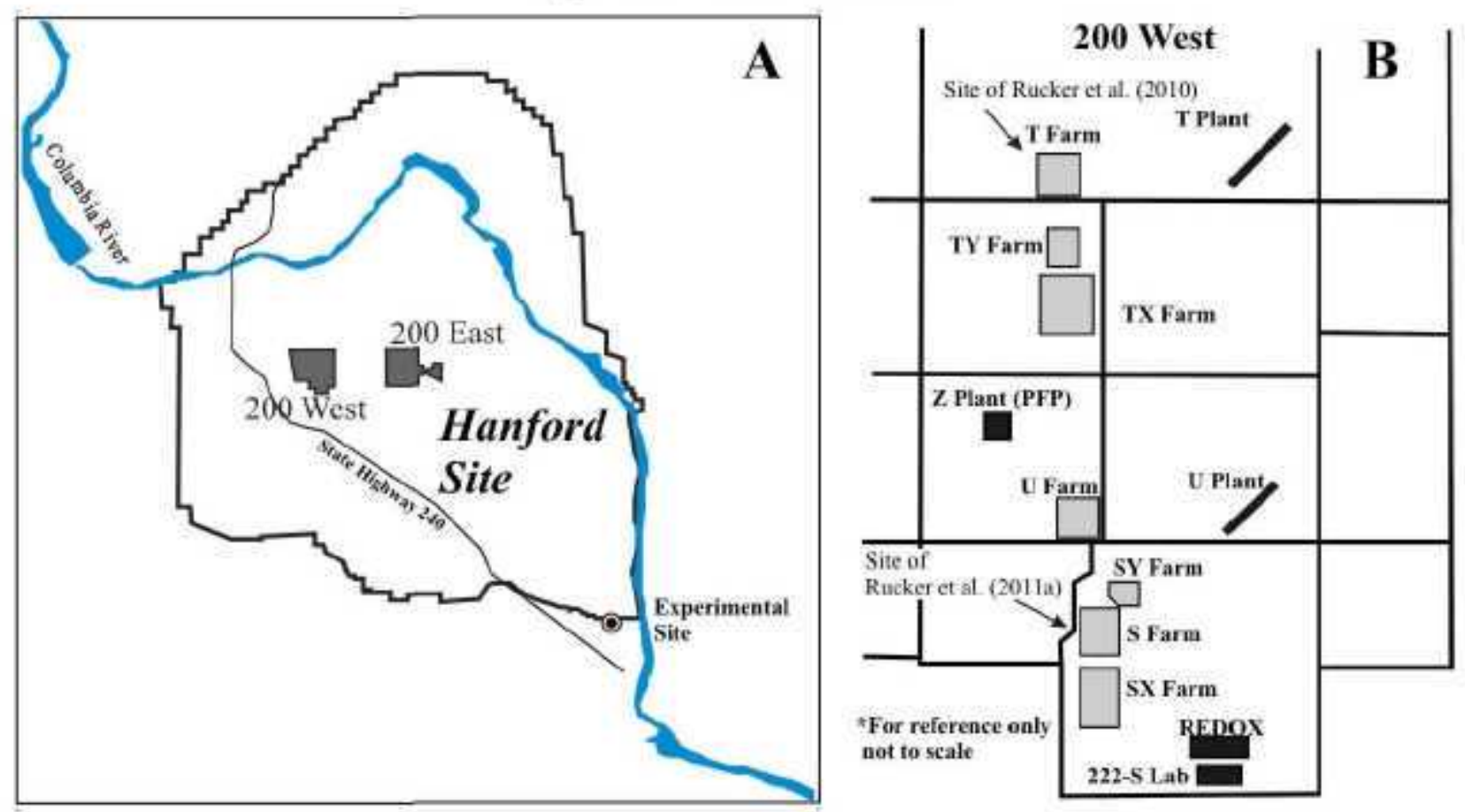

A) Site location for the LE-ERT field validation relative to the tank farms located in 200 east and 200 west. B) Location of tanks farms within 200 West Area and published studies where the LE-ERT method has been conducted.

\subsubsection{Experimental Design}

The resistivity experiment was designed to mimic a Hanford tank farm setting, where a hypothetical tank leak created a saline plume in the vadose zone. The standard SST is $23 \mathrm{~m}$ in diameter and approximately $9 \mathrm{~m}$ tall from base to dome. The sediment cover from the apex of the dome to ground surface is about $2.5 \mathrm{~m}$. The tanks were constructed of concrete with a carbon steel liner and a thick concrete-asphalt external layer to protect the tanks from corrosion. An electrically resistive round plastic container was used to approximate the tank.

The dimensions of the container were $1.8 \mathrm{~m}$ diameter and $0.45 \mathrm{~m}$ high; the container was buried where the top was even with the ground surface. Figure $6 \mathrm{~A}$ and $6 \mathrm{~B}$ shows the container location.

Surrounding each tank is a series of steel-cased monitoring dry wells, completed approximately 22 to $45 \mathrm{~m}$ below ground surface. An entire Hanford tank farm could have more than 60 dry wells. A number of groundwater wells, used for water sampling and analysis, are also positioned 
outside the tank farms. Together, the set of vadose and groundwater wells form a broad distribution of coverage for LE-ERT imaging. For the pilot-scale experiment, a series of 27 steel wells were placed around the container in an arrangement that was similar to tank B-105 in the B tank farm (RPP-10098, Field Investigation Report for Waste Management Area B-BX-BY). The wells were replicated by a solid core stainless steel rod, $0.019 \mathrm{~m}$ diameter and $1.8 \mathrm{~m}$ long, and were driven into the ground by an electric percussion hammer. Figure $6 \mathrm{~A}$ and $6 \mathrm{~B}$ shows the layout of the wells relative to the tank. In addition, 70 surface electrodes and 10 buried electrodes, both acting as point source electrodes, were installed as part of the experiment to provide a basis for comparison of the LE-ERT results. The base separation of the surface electrodes was $0.3 \mathrm{~m}$. The depth electrodes were placed at the top of the amended soil target $(0.6 \mathrm{~m})$, at the base of the target $(0.9 \mathrm{~m})$, and significantly below the target $(1.5 \mathrm{~m})$.

Figure 6. Plastic Container Location.

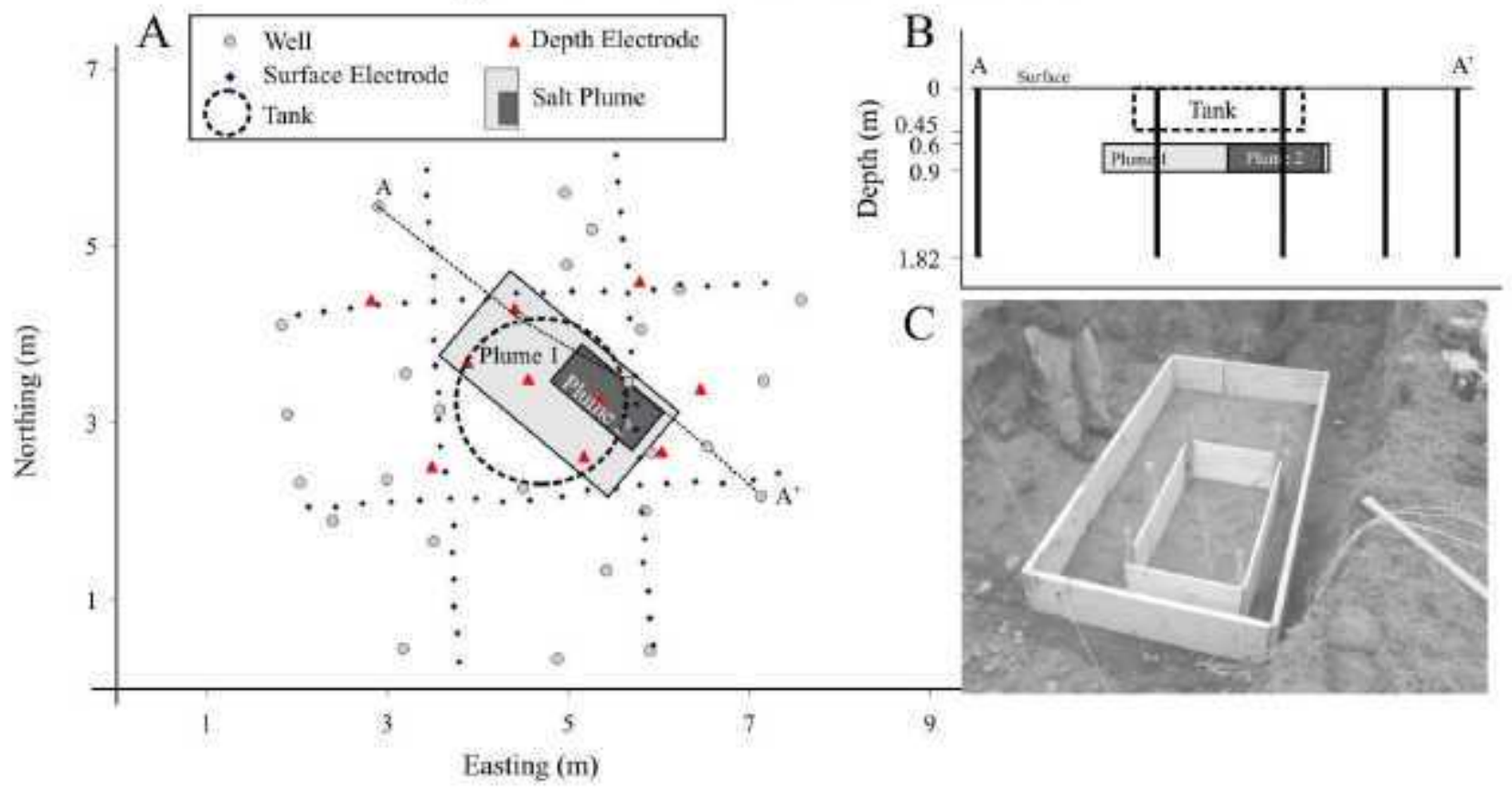

A) PJan view map of the validation experiment, showing the different point and long electrodes, tank, and simulated plumes. B) Profile view through A-A . C) Photo of forms used to place amended soil for LE-ERT target identification.

The simulated plume was constructed by removing the soil, amending it, and repacking into forms. Figure $6 \mathrm{C}$ shows a photo of the dug out with temporary wooden forms used for establishing plume dimensions. The hand-packing option allowed control over the shape, size, and properties, providing a fixed and known target to image. Figure $6 \mathrm{~A}$ and $6 \mathrm{~B}$ shows the position of the plume with dimensions of $2.43 \mathrm{~m}$ by $1.21 \mathrm{~m}$, and $0.3 \mathrm{~m}$ in height. The plume is stationed at the edge of the tank, rotated to the northwest, and laying flat. The plume was constructed by mixing a solution of sodium thiosulfate pentahydrate $\left(\mathrm{Na}_{2} \mathrm{~S}_{2} \mathrm{O}_{3} \cdot 5 \mathrm{H}_{2} \mathrm{O}\right)$ with the soil in a gas-powered cement mixer. This salt was chosen due to its use on the Hanford Site for many other experiments involving resistivity imaging of plumes (RPP-30121, Tank 241-S-102 High Resolution Resistivity Leak Detection and Monitoring Testing Report and RPP-RPT-30976, Surface Geophysical Exploration of S Tank Farm at the Hanford Site). Two concentrations, 20,000 and 40,000 milligrams per liter $(\mathrm{mg} / \mathrm{L})$, were mixed to produce a low resistivity outer 
plume (Plume 1) and a very low resistivily inner plume (Plume 2). The electrical resistivity of the solutions was approximately 0.5 and $0.25 \mathrm{ohm}-\mathrm{m}$. The amount of solution added to the soil equated to an increase of 3 percent by weight for the outer plume and 5 percent for the inner plume.

The addition of a low volume of solution was meant to prevent grayity drainage of the plume away from the source and avoid diffusion processes that would likely snear the plume edges within the time scale of the survey. The fiual resistivity values of the soil representing the inner and outer plume were roughly 190 and $320 \mathrm{chm}-\mathrm{m}$. respectively. This is in contrast to an ayerage background of approximately $1.320 \mathrm{ohm}-\mathrm{m}$ (taken from ten measurements ranging from 580 to $2,840 \mathrm{ohm}-\mathrm{m}$ to a depth of $1 \mathrm{~m}$ ). The contrast between background and target in this study closely resembled the values found in recent resistivity studies on site. For example. Rucker et al., 2009 showed results from a resistivity survey conducted at the BCCT site on the Hanford site. with contaminated soil resistivity values ranging from 10 to $250 \mathrm{ohm}-\mathrm{m}$ and background yalues in excess of $1,000 \mathrm{ohm}-\mathrm{m}$.

\subsubsection{Point Electrode Validation}

To conduct the resistivity measurements, a SuperSting R8 with two 56-channel switchboxes (manufactured by Advanced Geosciences, Inc. in Austin, Texas) were used to connect with all 112 electrodes at once. The electrodes were connecled to the resistivity acquisition system using 16-gauge multi-strand copper wire, which required two intermediate 56-channel patch panels to make the actual connection of the wires to the switchbores. The patch panels were constructed so that a dedicated connector could be linked to each individual channel on the switchbox. To minimize noise a 3.6 second (s) sampling wiodow was used. Each measurement was stacked with three windows and data rejection was set to two percent error. Full reciprocals for data acquired with the PP array were oblained to gain an understanding of the measurement error. The reciprocal measurements were acquired with a forward set and reverse set; the infinite poles being switched for each set. Reciprocal data from the pole-dipole (PD) and DD arrays with the LE-ERT method were not acquiced.

Figures 7A through $7 \mathrm{C}$ show a series of plots that represent data statistics for the poinl electrote data, including the surface and buried electrodes. For the 80 available point electrodes, there are a total of 3,160 possible non-reciprocal measurement pairs. Figure 7A shows the transfer resistance versus electrode separation distance for 2.995 data values from the forward set. after removal of low quality data. The data from closer electrode spacing displays the highest variability and the remaining data appear to fall off linearly in semi-log space. Figure 7B shows the apparent resistivity dala versus electrode separation, where ranster resistauce was converted to apparent resistivity $\left(\rho_{\mathbf{a}}\right)$ using:

$$
f_{0}=2 \pi r \frac{V}{j},
$$

where, $r$ is the separation between the transmitter and receiver electrodes and V/ is the transfer resistance, calculated as measured voltage divided by input current. The data from closer electrode spacing appears to have lower resistivity than the larger spacing. likely indicating that the near surface is slightly more conductive. Finally, Figure 7C shows the reciprocal etTor (RE) for the measurements calculated as: 
$R E=\frac{(v / t)_{f}-(v / l)_{f}}{(v / l)_{f}} \cdot 100$

where, subscript $f$ and $r$ represent the forward and reverse acquisition data for the same measurement pair. The difference between the pair of measurements should ideally be zero and any deviation from zero may give a measure of the quality of the data (Chambers et al., 2010. "Hydrogeophysical Imaging of Deposit Heterogeneity and Groundwater Chemistry Changes during DNAPL Source Zone Bioremediation"). Assessing erors due to high contact resistances, randon instrument etrors, and sporadic errors due to background noise is easily conducted using the reciprocal etror (Slater et al., 2000. "Cross-hole Electrical Imaging of a Controlled Saline Tracer [njection").

After addressing the reverse data set to remove low quality data and aligning with the forward set, 2820 values remain for each of the forward and reverse data sets. Of these. 2750 from each set were shown to be within $5 \%$. which are shown in Figure $7 \mathrm{C}$. The data with the closer electrode spacing appears to have the higher reciprocal enors. In addition, the forward data set are, on average, lower than the reverse data set. It is unclear what could be causing the bias.

Data processing and inversion for the point electrode data was conducted with RES3DINVx64. version 3,04.26 (Geotomo Software. Malaysia). For the point electrode data several inverse model cell sizes were tested to gain an understanding of resolution versus target fidelity. Layering of the models was consistent throughout all of the tests, developed from a telescoping sequence with a top layer thickuess of $0.1 \mathrm{~m}$ and bottom layer thickness of $0.5 \mathrm{~m}$. Three tests were run that included square cells of $0.15 \mathrm{~m} .0 .3 \mathrm{~m}$, and $0.6 \mathrm{~m}$. statistics for the models are listed in Table 1.

The results of the inversion. showing the 3D representation of targets within the domain. are presented in Figure 7D to $7 \mathrm{~F}$ for inverse model cell sizes of $0.6,0.3$, and $0.15 \mathrm{~m}$, respectively. The resistiyity data are presented at two isopleths, with the lower resistivity isopleth as an opaque body and the larger resistivity isopleth as a transparent body. The value of the resistivity presented for each isopleth was chosen to encompass roushly the same volume of material for all models and the exact values are shown on the color scales to the right of the figure. The smaller body equated to approximately 0.85 meters cubed $\left(\mathrm{m}^{3}\right)$ while the larger body equated to approximately $4.7 \mathrm{~m}^{3}$. In all three instances, a target is observed at the location of the pre-constructed plumes, shown in the figures for reference. For all cases, both the smaller and larger isopleth appear offset towards the western edge of the pre-constucted plumes. Additionally, there are other targets within the domain that are consistent among the models, notably the very low resistivity at the surface on the southwest side of the domain and a marginally low resistivity body on the northeast corner. It is unknown what is causing these features to appear in the results. 


\section{Figure 7. Data and Inversion Results from the Point Electrodes.}
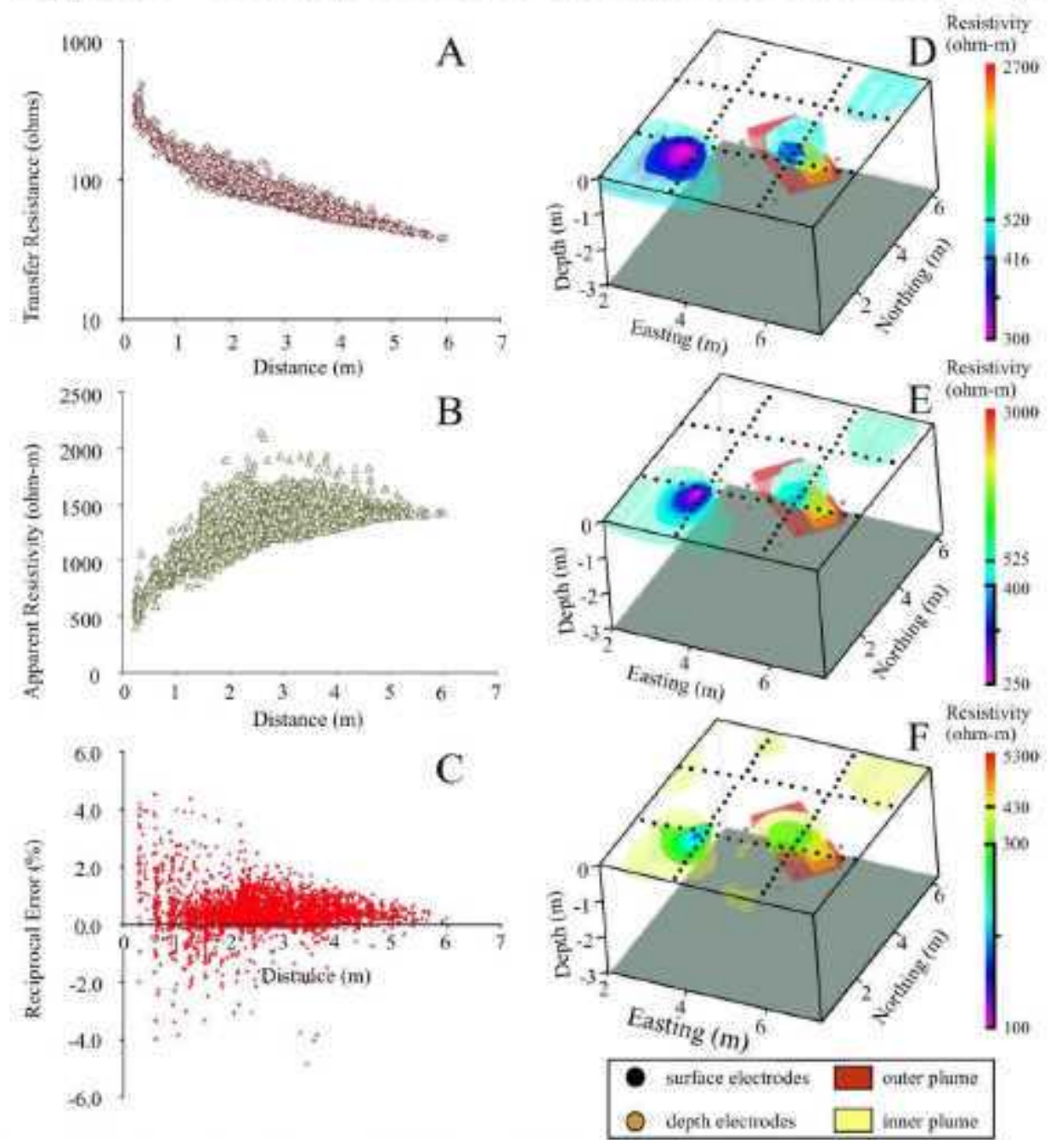

A) Transfer resistance (ohms) vs. electrode separation distance B) Apparent resistivity (ohm-m) vs, electrode separation distance. C) Reciprocal error vs. electrode separation distance, showing a slight underestimation in the forward data compared to the reverse data set. D) Inverse model results for a square model grid of $0.6 \mathrm{~m}$ showing two isopleths of 520 ohm-m (translucent) and $416 \mathrm{ohm}$-m (opaque). E) Inverse model results for a square model grid of $0.30 \mathrm{~m}$ showing two isopleths of $525 \mathrm{chm}-\mathrm{m}$ (translucent) and 400 ohm-m (opaque). F) Inverse model results for a square model grid of $0.15 \mathrm{~m}$ showing two isopleths of $430 \mathrm{ohm}-\mathrm{m}$ (translucent) and $300 \mathrm{ohm}-\mathrm{m}$ (opaque).

Regarding target fidelity, the smallest cell size of $0.15 \mathrm{~m}$ (Figure 7F) appears to replicate the target edges, especially the bottom and top edge, better than the other two larger cell sizes. The drawback is that potentially more false targets appear within the domain, as shown in the upper layers of the model. Since it would be impractical to attempt to sample all of the soil measured during initial design, it is possible that the smaller targets identified in Figure $7 \mathrm{~F}$ are actual subsurface features. This is supported by the observation that the lowest values of apparent resistivity, shown at close electrode spacing in Figure 7B, are observed in the very near surface of Figure 7F. However, the sizes of the small targets are on par with the cell size of the $0.3 \mathrm{~m}$ simulation and should have been imaged in Figure 7E if they were true targets. 
Table 1. Statistics for the Point Electrode Inversions.

\begin{tabular}{|c|c|c|c|c|}
\hline Cell Size $(\mathbf{m})$ & Rows, Columns, Layers & Total Cell Count & $\begin{array}{c}\text { Total Data } \\
\text { Count }\end{array}$ & Figure Number \\
\hline 0.15 & $34 \times 41 \times 14$ & 19,516 & 2750 & $7 \mathrm{~F}$ \\
\hline 0.3 & $19 \times 21 \times 14$ & 5,586 & 2750 & $7 \mathrm{~B}$ \\
\hline 0.6 & $10 \times 11 \times 14$ & 1,540 & 2750 & $7 \mathrm{D}$ \\
\hline
\end{tabular}

3.2.3.1 Model Resolution Formally, the model resolution $(R)$ is a matrix that is computed from the Jacobian and other model constraints and describes how well the inversion model resolves the subsurface (Day-Lewis et al., 2005, "Applying Petrophysical Models to Radar Travel Time and Electrical Resistivity Tomograms: Resolution-Dependent Limitations"):

$R=\left(J_{i}^{T} J_{i}+C\right)^{-1} J^{T} J$

$R$ may be viewed as a filter that blurs the true values of the subsurface resistivities

(Stummer et al., 2004, "Experimental Design; Electrical Resistivity Data Sets that Provide Optimum Subsurface Information"):

$r^{\text {ant }}=R r^{\mathrm{rw}}$

where $\mathrm{r}^{\text {est }}$ is the vector of the estimated model parameters obtained by applying Eq. (4) and $\mathrm{r}^{\text {true }}$ is the true subsurface resistivity. The values within $R$ will range from zero to one, a perfectly resolved model is one in which the diagonals are equal to a value of one. (Stummer et al., 2004) stated that values greater than 0.05 were considered acceptable, based on their analysis for two-dimensional (2D) resistivity profile inversions. For 3D work, such as presented here, we will accept a lower resolution based on the lower spatial electrode density. From a computational standpoint, calculating the resolution matrix is expensive (Loke et al., 2010, "Fast Computation of Optimized Electrode Arrays for 2D Resistivity Surveys" and Wilkinson et al., 2006, "Improved Strategies for the Automatic Selection of Optimized Sets of Electrical Resistivity Tomography Measurement Configurations") presented ways to help reduce the number of operations. In this work we used the method of (Loke et al., 2010) as implemented in RES3DINVX64.

Alumbaugh and Newman, 2000, "Image appraisal for 2-D and 3-D Electromagnetic Inversion" used the model resolution to understand the effects of key assumptions from electromagnetic inversion models. Stummer et al., 2004; Wilkinson et al., 2006; and Loke et al., 2010 used the model resolution to derive the best combination of surface measurements to obtain improved representation of subsurface targets for $2 \mathrm{D}$ problems. Applying a hybrid of these approaches, we investigated the consequence of typical decisions made for inverting resistivity data to resolve a target, including model parameters (inverse model cell size) and electrode density. Figure 8 shows a series of model resolution results, plotted in $\log$ scale, for a group of four models. Figure $8 \mathrm{~A}$ through $8 \mathrm{C}$ shows the model resolution for the original electrode layout presented in Figure 6 with an inverse model cell size of $0.3 \mathrm{~m}$ (see Figure 7E for resistivity results). The three figures are plotted for the first model layer (at a depth $0.05 \mathrm{~m}$ ), through the center of the amended soil plume (at $0.8 \mathrm{~m}$ ), and below the plume (at $1.6 \mathrm{~m}$ ). At the surface, the results show that the model is best resolved along the lines of electrodes; the maximum resolution is 
only 0.024. A solid line is placed at the 0.01 resolution contour interval for reference. For the layer through the center of the plume, the highest resolution is coincident with the target, which may be an affect of both depth electrode locations and target properties; the maximum resolution for this layer is 0.076 . The lowest layer on Figure $8 \mathrm{C}$. shows the highest resolution values coincident with the four point electrotes at that depth.

For the remaining nodels, we increased the inverse model cell size to twice that of the electrode spacing to $0.6 \mathrm{~m}$ (shown in Figures 8D through $\mathrm{F}$ ), reduced the electrode coverage to every other electrode along each line while maintaining a 0.3 m inverse model cell (Fipures $8 \mathrm{G}$ through $4 \mathrm{I}$ ), and eliminated the depth electrodes but kept the original surface electrodes and cell size of $0.3 \mathrm{~m}$ (Figures 8J through 8L). Although intuitive, the best results were obtained by increasing the model cell size to $0.6 \mathrm{~m}$, with the maximum resolution value of 0.35 observed for the layer though the plume. The worst resolution can be seen in the model without depth electrodes. Surprisingly. however, reducing the surface electrodes had little effect on the overall resolution. When designing field surveys with a tinite number of channels on the resistivity meter, these results suggest that surface electrodes can be sacrificed to ensure adequate electrode coverage deeper in the subsurface. 


\section{Figure 8. Model Resolution for Point Electrodes.}

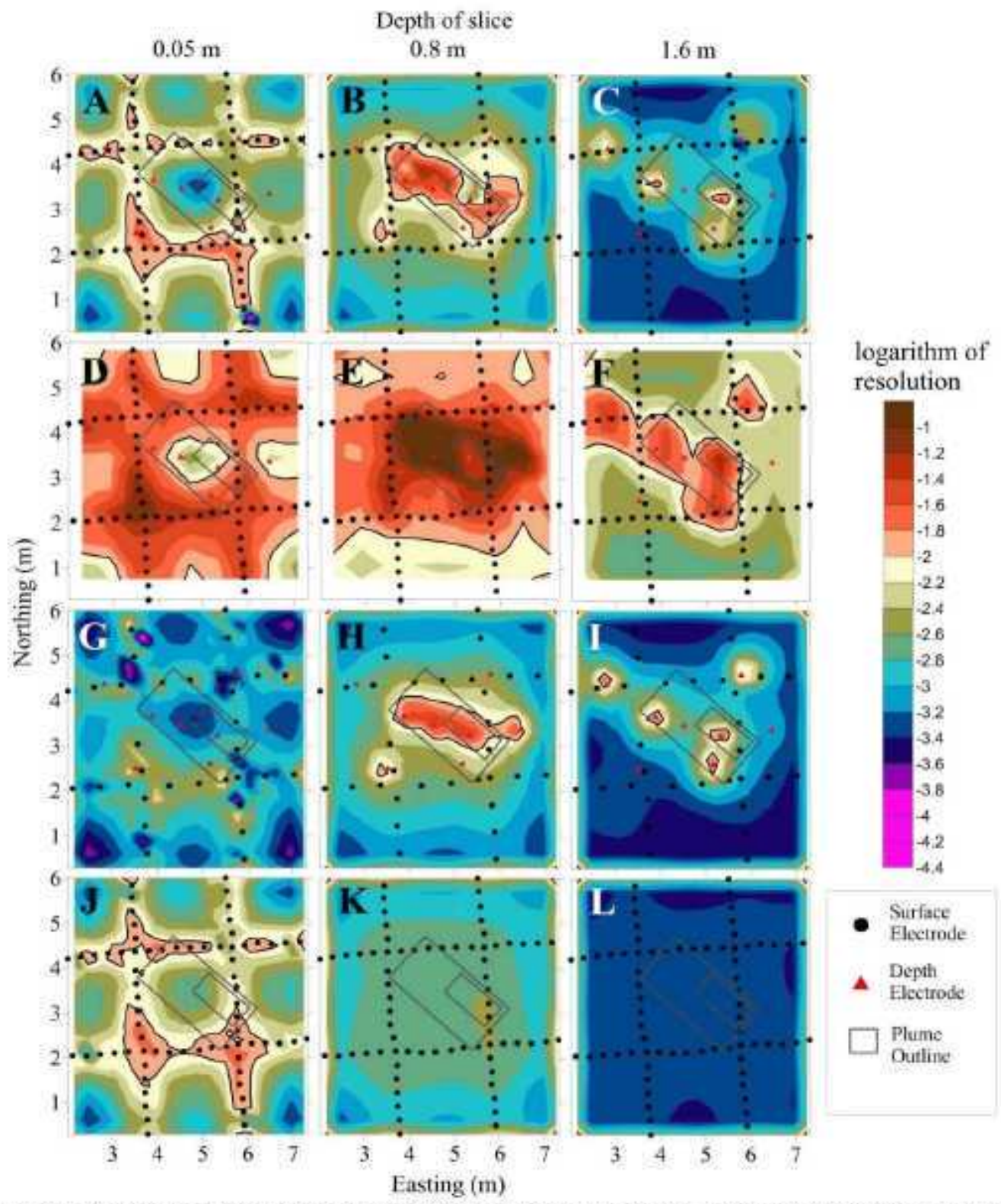

A) Slice at $0.05 \mathrm{~m}$ with clectrode separation of $0.3 \mathrm{~m}$ and inverse model cell of $0.3 \mathrm{~m}$. B) Slice at $0.8 \mathrm{~m}$ with electrode separation of $0.3 \mathrm{~m}$ and inverse model cell of $0.3 \mathrm{~m}$. C) Slice at $1.6 \mathrm{~m}$ with electrode separation of $0.3 \mathrm{~m}$ and inverse model cell of $0.3 \mathrm{~m}$. D through F) Equivalent layers for increased cell size of $0.6 \mathrm{~m}$. G through I) Reduced electrode density to $0.6 \mathrm{~m}$ separation and modet cell of $0.3 \mathrm{~m}$. J through L) Equivalent of A through $\mathrm{C}$ but without depth electrodes. 


\subsubsection{Long Electrode Validation}

3.2.4.1 Pole-Pole Acquisition. The electrical data acquired on the wells using the PP array are shown in Figure 9, similar to the plots presented in Figure 7. The total number of combinations with 27 wells using the PP array is 351 ; only 5 measurements were eliminated from the dataset. The transfer resistance shows a power function relationship with distance, with an exponent of -0.71 . The point electrode data showed a similar relationship with an exponent of -0.69 .

The close spaced data for the apparent resistivity data in Figure 9B shows a lowered resistivity than the more distant data, but this likely has more to do with the incorreet conversion of transfer resistance to apparent resistivity than the properties of the earth. Rucker et al., 2010 demonstrated how to convert transfer resistance measurements using long electrode transmitters and point electrode receivers to apparent resistivity by incorporating aspects of the well length. No known conversion exists for the long electrode to long electrode combinations and Eq. (1) was used instead. The reciprocal error in Figure $9 \mathrm{C}$ shows a lower degree of error than the point electrode data, with no spatial bias. However, there still appears to be a slight underestimation by the forward data acquisition set.

Figure 9. Electrical Data Statistics from the Long Electrodes Using the Pole-Pole Array.
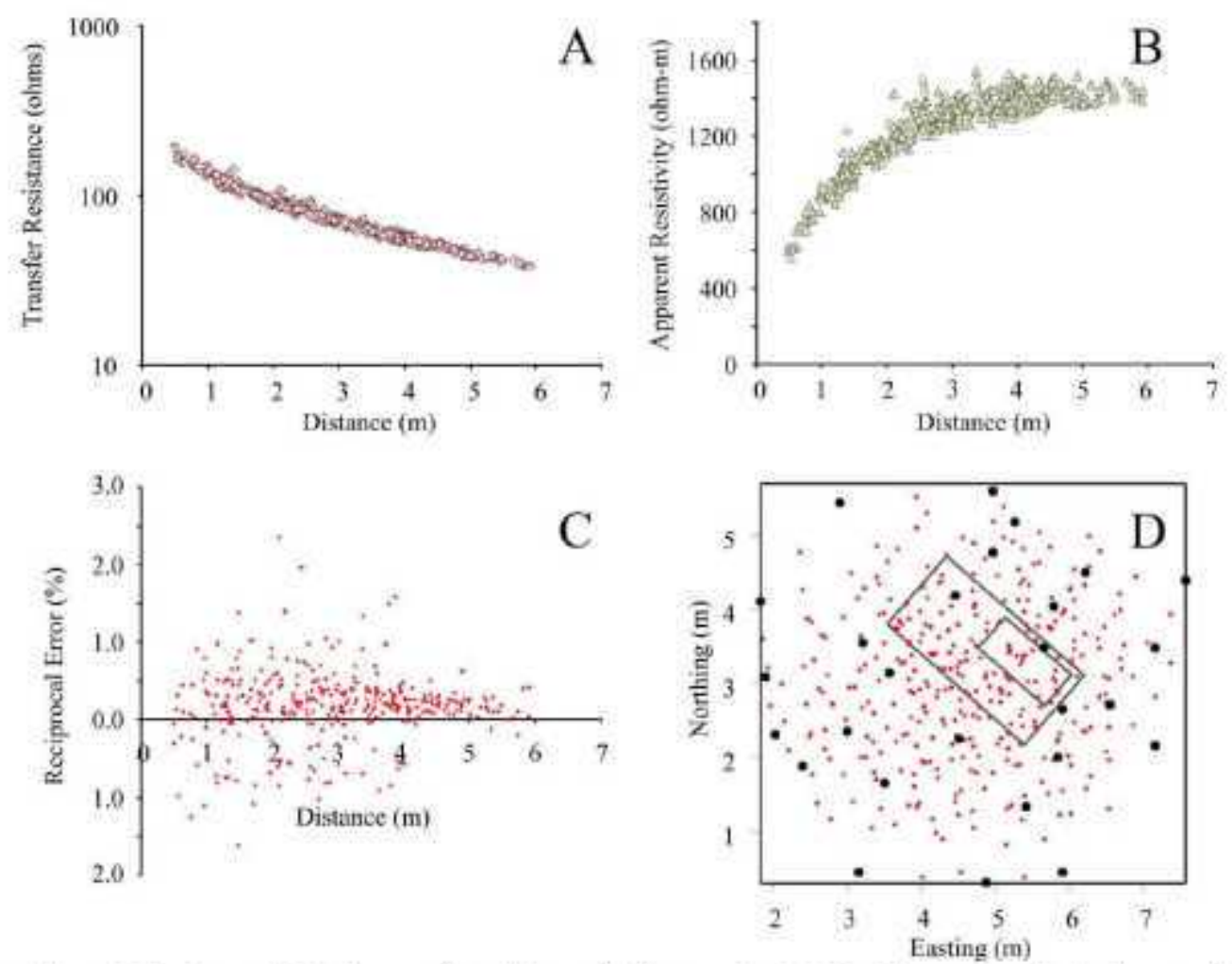

A) Transfer resistance (ohms) vs, electrode separation distance B) Apparent resistivity (ohm-m) vs, electrode separation distance. C) Reciprocal error electrode separation, showing a slight underestimation in the forward data compared to the reverse data set.

D) Point cloud of data density.

Figure 9D shows a point cloud of data from the long electrodes, created by taking the midpoint between each transmitter and receiver electrode combination, similar to a pseudosection for $2 \mathrm{D}$ profiles. The plot shows a high concentration of data points near the center and towards the plume. Although a qualitative measure, it will be a valuable comparison for the PD and DD. 
point cloud, presented below, to ensure that the latter two arrays hat sufficient coverage of the subsutface for comparison.

The results of inverting the PP LE-ERT data are presented in Figure 10. We iuvestigated two cell sizes: $0.3 \mathrm{~m}$ (Figure 10A, C. and E) and $0.6 \mathrm{~m}$ (Figure 10B, D. and F). The resistivity plots in Figures $5 \mathrm{~A}$ and $5 \mathrm{~B}$ represent the first layer of the model at $0.1 \mathrm{~m}$. Rucker et al., 2010 demonstrated that the targets teod to create the largest footprint at the surface of the nodel, likely due to the maximun curent density at the surface elevation. The figures show that both models replicated the amended soil tar set with relatively good accuracy, given the significantly lower number of electrodes and data compared to the point electrode models. In addition, the LE-ERT results display the notheast and southwest sutficial targets imaged in the point electrode models.

The model resolution of the two inverse model cell sizes is preseuted for the sulface (Figures 10C and 10D) and for a layer through the center of the plume at a depth of $0.8 \mathrm{~m}$ (Figures 10E and 10F). For direct comparison with the point electrode motels, the same color scale was used. with a solid line contour through the 0.01 value. Similar to the results of the point electrode results, the larger cell size tended to produce a better resolved model. However. the LE-ERT models have a lower average and maximun resolution than the point electrode models (Figures 8A through 8F) for the same cell size. The maximum LE-ERT model resolution for the $0.3 \mathrm{~m}$ cell size at the surface was 0.008 , compared to a value of 0.024 for the equivalent point electrode model; the maximum LE-ERT model resolution for the $0.6 \mathrm{~m}$ cell size was 0.038 versus a value of 0.093 for the point electrode model. The lower model resolution values for the long electrode model were likely due to the significant difference in the number of electrotes. 
Figure 10. Inversion Results for the LE-ERT for the Pole-Pole Array.
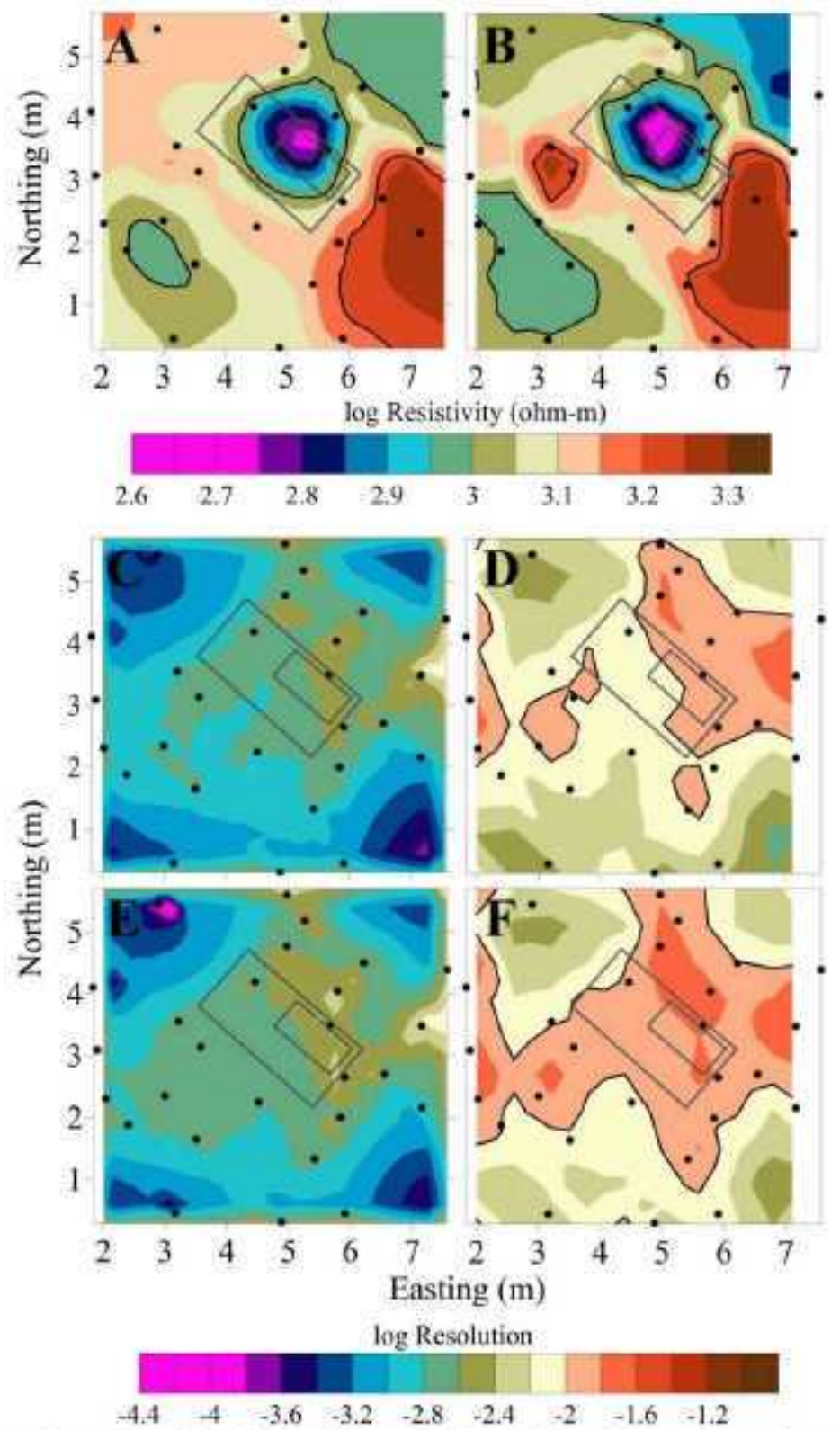

A) Resistivity of the top layer of a model with cell size of $0.3 \mathrm{~m}$. B) Resistivity of the top layer of a model with cell size of 0.6 $\mathrm{m}$. C) Resolution of the top layer for a cell size of $0.3 \mathrm{~m}$. D) Resolution of the top layer for a cell size of $0.6 \mathrm{~m}$. E) Resolution of the layer through the plume $(0.8 \mathrm{~m})$ for a cell size of $0,3 \mathrm{~m}$. F) Resolution of the layer through the plume $(0.8 \mathrm{~m})$ for a cell size of $0.6 \mathrm{~m}$.

NOTE: Feature legend for the contour plots are the same as Figure 8.

3.2.4.2 Pole-Dipole and Dipole-Dipole Acquisition. Similar to the PP array acquisition with long electrodes, data from both the PD and DD arrays were acquired for the pilot-scale validation test. The difference is in the exhaustive combination set obtained with the PP array versus a smaller subset of data acquired with DD and PD arrays. At the time of acquisition in 2007, there were no means to create a complete data command file for randomly distributed electrodes for $3 \mathrm{D}$ analysis using the Super Sting R8 resistivity meter. The manual creation of the command file meant that not all pairs were viable, such as those with an extremely large geometric factors or a 
negative transfer resistance, and that the best combinations were not necessarily included in the command file. Of the $9950 \mathrm{PD}$ and $7189 \mathrm{DD}$ measurenents, 3995 (for PD) and 4546 (for DD) were retained for inverse modeling based on previously outlined data reduction practices. To illustrate there was no spatial bias in the data acquisition and the region surrounding the soil plume had symmetric coverage, a point cloud was created for each amay. Figures $11 \mathrm{~A}$ and $11 \mathrm{~B}$ show how the point clouds were created for the PD and DD arays, respectively. Figures $11 C$ and $11 \mathrm{D}$ show that the results of the point cloud, like the PP alray, produce ample coverage from all of the wells around the target. The last two subplots in Figure 11 show the transfer resistance versus the geometric factor for $\mathrm{PD}$ and $\mathrm{DD}$ arrays. The gemetric factor (CF) was calculated as (Telford et al., 1990):

$G F=\left(\left|\frac{1}{A M}\right|-\left|\frac{1}{A N}\right|-\left|\frac{1}{B M}\right|+\left|\frac{1}{B N}\right|\right)^{-1}$

where A, B, M, and N are the locations of the transmitter and receiver pairs of electrodes. For the PP array, the geometric factor reduces to the disiance between transmitter and receiver electrodes (Figures 7A and 9A). Both PD and DD alrays of Figure 11E and 1IF show a linear relationship of transfer resistance versus geometric factor on a $\log -\log \mathrm{plot}$, and the exponents for the power fit are -0.72 (for PD) and -0.75 (for DD). These are similar to exponents obseryed with the PP array on both long and point electrodes. It is interesting to note the larger data point spread at higher geometric factors. likely attributed to the lower signal to noise ratio for both arrays compared to the PP array.

The inverse model results for the PD and DD arrays, using a consistent inverse model cell size of $0.3 \mathrm{~m}$. are shown in Figure 12. Data from only the top model layer a1 $0.1 \mathrm{~m}$ are presented in all images. A different color scale was developed for this figure. due to the range of resistivity values of the PD and DD alray being broader than the PP array. However, a consistent model resolution color scale was retained for direct comparison to all previous models. The most remarkable aspect of the resistivity results for $\mathrm{PD}$ and DD is the placement of the low resistivity target to the east of the actual target in both examples despite generally higher model resolution values. The reasons for the offset in the target's location may be due to I) the non-optimal sampling from electrode pairs, and 2) noise. RPP-RPT-49129 also showed a displaced reconstructed target in a molel validation with long electrodes for conditions with high noise. When evaluating individual transmitter electrode pairs around the target. some pairs are represented reasonably well in the data as observed by the number of accompanying receiver electrode pair measurentents, while others have fewer receiver measurements.

Additionally, when observing transmitter and recejver electrode pairs using combinations that include the long electrode just to the northwest of the reconstructed target, generally a lower geometric factor is observed relative to other pairs where the resistivity is higher (e.g., at the actual target location). Then. when plotting transfer resistance data from subsets of transmitter well pairs, those with higher geometric factor have more data scatter and higher variability in the power fit function. Depending on transmitter well pair, the exponent for the power fit can range from -0.55 to -0.87 , with the higher exponent attributed to wells in the target and thus a higher resistivity. 
Figure 11. Electrical Data Statistics for the Long Electrode using Pole-Dipole (PD) and Dipole-Dipole (DD) Arrays.

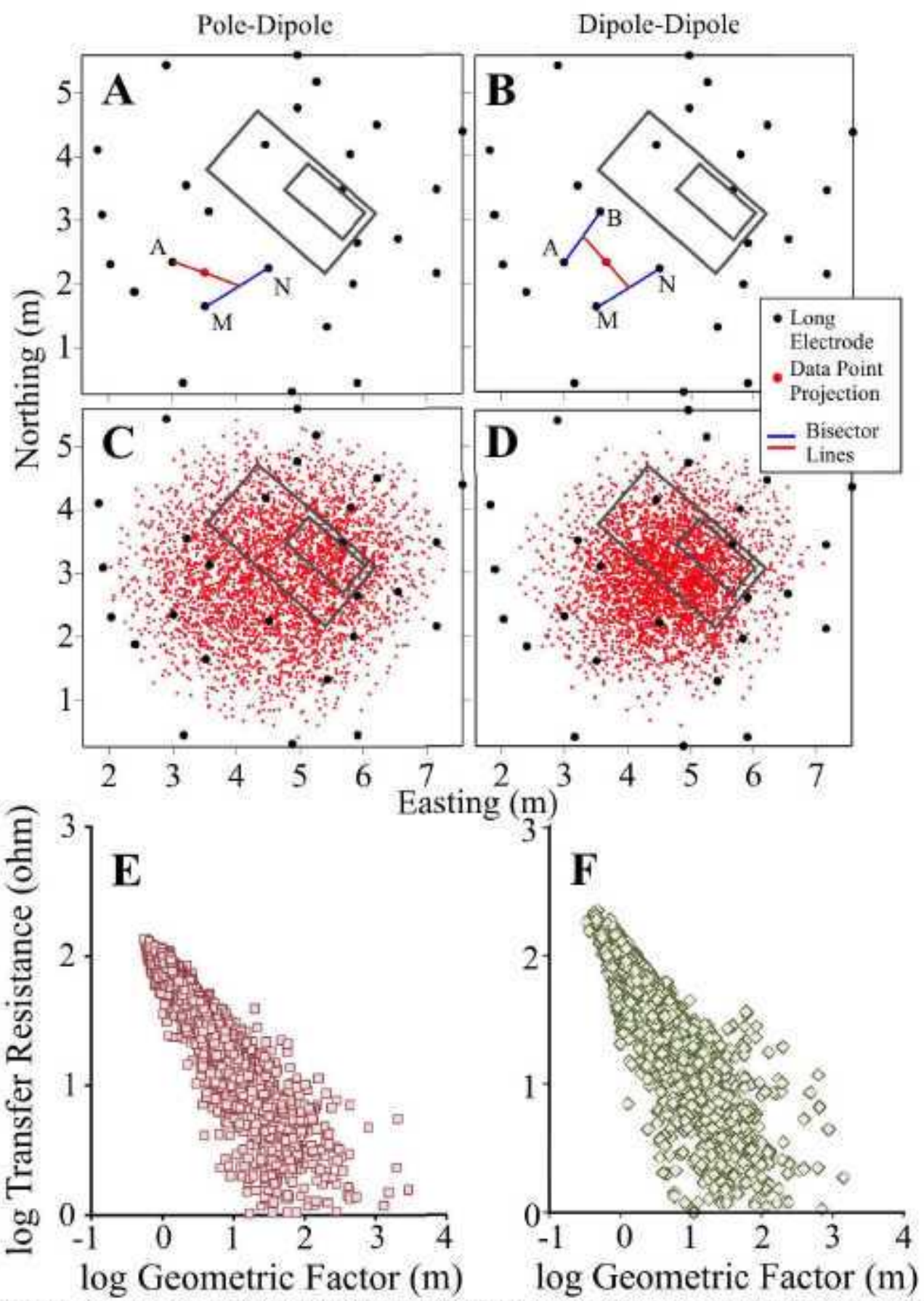

A) Example calculation of data point projection using bisector lines for PD. B) Example calculation of data point projection using bisector lines for DD. C) Point cloud for PD. D) Point cloud for DD. E) Transfer resistance versus geometric factor for PD. F) Transfer resistance versus geometric factor for DD. 


\section{Figure 12. Inversion Results for the LE-ERT for the PD and DD Arrays.}

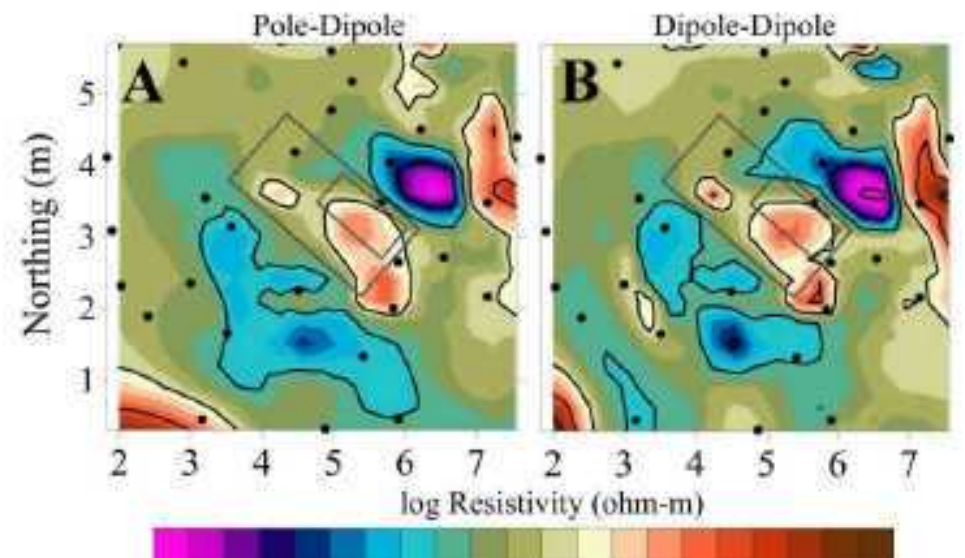

$\begin{array}{llllllllllll}2.2 & 2.35 & 2.5 & 2.65 & 2.8 & 2.95 & 3.1 & 3.25 & 3.4 & 3.55 & 3.7\end{array}$

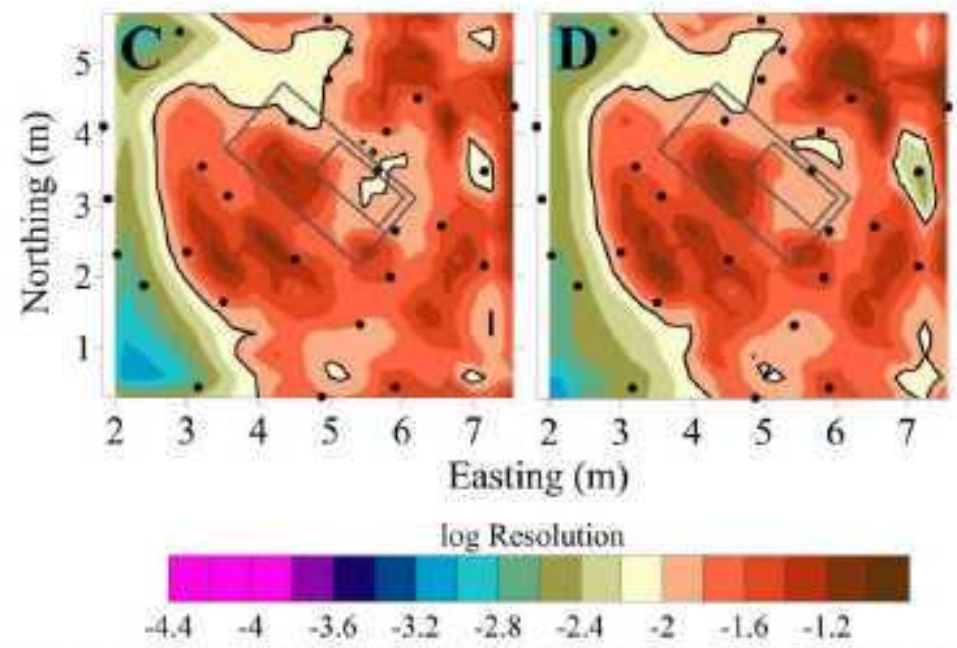

Feature legend for the contour plots are the same as Figure 8. A) Resistivity of the top model layer with cell size of $0.3 \mathrm{~m}$ for PD artay. B) Resistivity of the top model layer with cell size of $0.3 \mathrm{~m}$ for DD array, C) Resolution of the top model layer for PD artay. D) Resolution of the top model layer for DD array.

\subsubsection{Summary of Validation}

In summary, when evaluating the fidelity of the target reconstruction, the point electrode method was shown to have the highest accuracy as long as depth electrodes were included. Even when the inverse model cell size was twice as large as the electrode separation, the target's location and depth were reproduced well. From a modeling perspective, the larger cell size actually created the highest model resolution values, with the lowest resolution observed from the model with no depth electrodes. Depth electrodes are important when surface electrodes are sparse, and arrays of depth electrodes buried in actual tank farm settings have proven to be a valuable means to evaluate historical leaks (RPP-RPT-49129).

The results from the LE-ERT method using the PP array were shown to be almost identical as the point electrode results in imaging the lateral extents of the plume. In contrast, the LE-ERT had a significantly lower number of electrodes and total measurements compared to the point 
electrodes. The drawback is the vertical position of the target is lost, as the current modeling algorithm forces most of the electrical current density in the upper portion of the model. Additionally, the model resolution values are generally lower for the LE-ERT method using the PP aray, Obviously. if there were a choice for survey design. a full spread of point electrodes on the surface and buried within the soil would be preferted. In some settings using point electrodes mily not be an option due to administrative or physical limitations at the site and the LE-ERT method may be a sujtable substitute for jdentifying targets.

The last two tests were condusted with the PD and DD anay using the long electrodes. The PD and DD arrays allowed a ten-fold increase in the number of measurements acquired compared to the PP array, yet only a fraction of an exhaustive dataset was acquired for either array. Geverally, the PD and DD showed higher voise in the transfer resistance data as a function of geometric factor. Although a target was identified in both PD and DD models, the noise and small subset of data likely attribuled to the poor performance in correctly positioning the reconstructed target at the known location. Remarkably, the PD and DD LE-ERT had siguificautly higher average model resolution values at the suface and deeper within the profile compared to any of the PP acquisition strategies, with a factor of ten higher than the long electrode and a factor of ejght higher than the point electrode PP jesults. This suggests that the PD and DD may be a better imaging method for deep surveys where a limited numbers of buried electrodes are avalable, provided the measurement noise could be reduced and optimum electrode pairs could be identified. Until then, the PP array will suffice in identifying simple target locations and extents.

\subsection{MAPPING WASTE SITES WITH MINIMAL INFRASTRUCTURE}

The first large scale resistivity characterization at the Hanford site using modern accuusition and processing nethods occurred at the BCCT site in the southern portion of 200 east. Figure 13 shows the location of the site. The site was used to dispose approximately $115 \times 10^{6}-\mathrm{L}$ of liquid waste with significant quantities of nitrate and technetium in a series of open trenches and concrete vaults (known as cribs). The resistivity survey is described in more detail in Rucker and Fink, 2007 and Rucker et al., 2009, but generally covered an area of approximately 54 hectacres (ha) with a series of linear transects of surface-based point electrodes. The transects were placed parallel and orthogonal to the trenches and cribs. The survey was a good test case for the resistivity method to define the extent of waste migration because the site had minimal infrastructure (Rucker, 2010. "The Application Of Masnetic Gradiometry and Electromagnetic Induction at a Former Radioactive Waste Disposal Sitery. The results showed that the method could identify the existence (and absence) of nitrate targets, as long as the data were processed in three dimensions. The confirmation was conducted by companing the resistivity data to the drilling results from four boreholes placed at selective locations around the site (PNNL-17821, Electrical Resistivity Correlation to Vadose Zone Sediment and Pore-Water Composition for the $B C$ Cribs and Trenches Area). Additionally, the resistivity method showed that the relative target intensities could be differentiated, where waste disposed in long open trenches had lower porewater concentrations of nitrate and slightly higher resistivity values than the cribs with higher nitrate concentrations and lower resistivity. The limitation was revealed to be in the 
vertical resolution of conducting resistivity surveys strictly from the surface and identifying the botiom edge of the very conductive plune. Additionally, the nethod showed a slight difference of about 3-5 $\mathrm{m}$ in identifying the top of the plune. The method performed as expected in 1) juentifying targets. and 2) distinguishing relative intensitjes of targets across the site. External review of the deployment (Geomatrix, 2005, Evaluation of Geophysical Technologies for Subsurface Characterization) led to further enhancements of the resistivity method for use at Hanford.

The BCCT was an exceptional case for verifying targets given the relatively high number of borehole samples. Due to expense, it is rare for a waste site outside of a tank farm to have more than one borehole for detailed laboratory analyses. However, many sites do have groundwater monitoring wells that can be used to conduct borehole geophysical logging (gamna, spectral gamma, and neution). More recently. temporary shallow direct push boles bave been installed to take a low number of samples and conduct additional borebole logging. Such is the case at the BX trenches, on the west side of BX tank farm (Figure 14), where a series of eight trencties received $15 \times 10^{6}$-L of sodium nitrate waste between 1954 and 1955 (PNNL-14128.

Characterization of Vadose Zone Sedintent: Borehole C3103 Located in the 216-B-7A Crib Near the $B$ Tank Farm). Three groups of wells were installed at the site. as listed in Table 1.

Several of the wells were installed specifically for geophysical well logging with spectral gamma. In general, the spectral gamma logging revealed high Cs-137 concentrations (upwards to 105 picocurie per gram [pCi/g]) in the top $10 \mathrm{~m}$ of soil, and in some cases Co- 60 (usually less than $0.2 \mathrm{pCi} / \mathrm{g}$ ) to depths of $14 \mathrm{~m}$ (DOE-GJO. 1998. Vadose Zone Characterization Project at the Hanford Tank Farms BX Tank Farm Report). The C 3104 borehole also Jevealed significant nitrate concentrations from depths 17 to $61 \mathrm{~m}$ below ground surface. 


\section{Figure 13. Site Map and Location of the BCCT on the Hanford Site.}

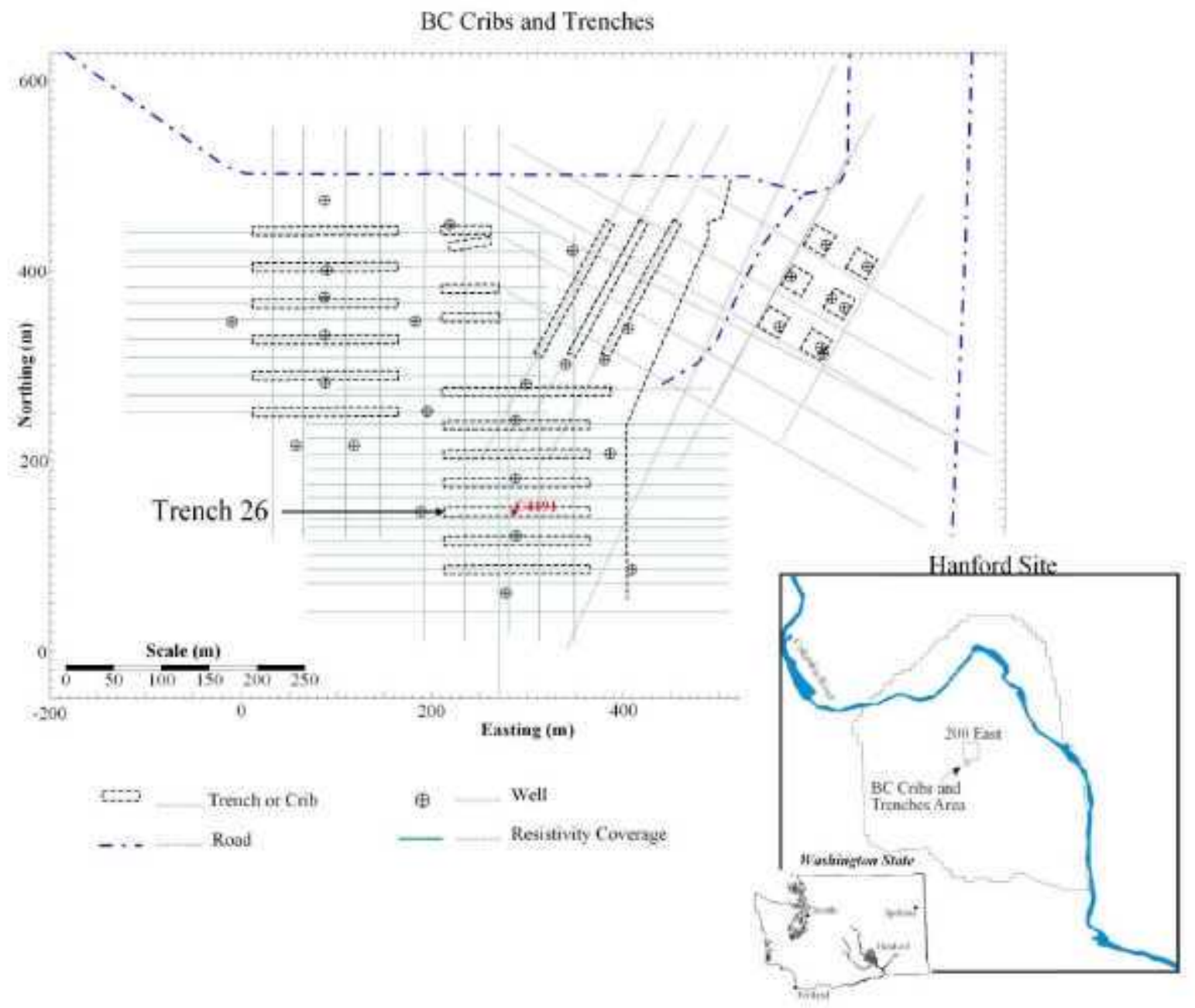

An electrical resistivity survey was conducted over the BX trenches as part of a broader survey to characterize the $\mathrm{B}, \mathrm{BX}$, and $\mathrm{BY}$ tank farms. A set of 15 resistivity transects were run orthogonal and parallel to the trenches. The data were acquired with a PP array, with a base electrode separation of $3 \mathrm{~m}$, and nominal line separation of $30 \mathrm{~m}$. A total of 61,200 voltage values were collected and the data were inverse modeled with the $3 \mathrm{D}$ inversion code Res3DINVx64 (Geotomo Software, Malaysia). The results, shown in Figure 14, are presented as a series of expanding transparent bodies of increasing resistivity representing 20,50 , and 100 ohm-m. The lowest resistivity values are beneath the B-37 trench, which received approximately three times the waste volume as any other trench. Only one recent borehole sampling event, sufficient for capturing the upper and lower bounds of the waste plume, is available for verification of the resistivity results. With this one borehole, however, we see that the resistivity distribution of the $100 \mathrm{ohm}-\mathrm{m}$ resistivity isopleth approximately matches the footprint of the trenches and the deepest extent of the nitrate concentrations of C3104. Other ancillary evidence, such as the spatial distribution of disposal volumes, coincides with the spatial distribution of the 
lowest resistivity values. The same results could also be seen for the trenches to the west of the T tank farm, presented in Rucker et al., 2010.

Figure 14. Three-Dimensional Electrical Resistivity Results of the BX Trenches.

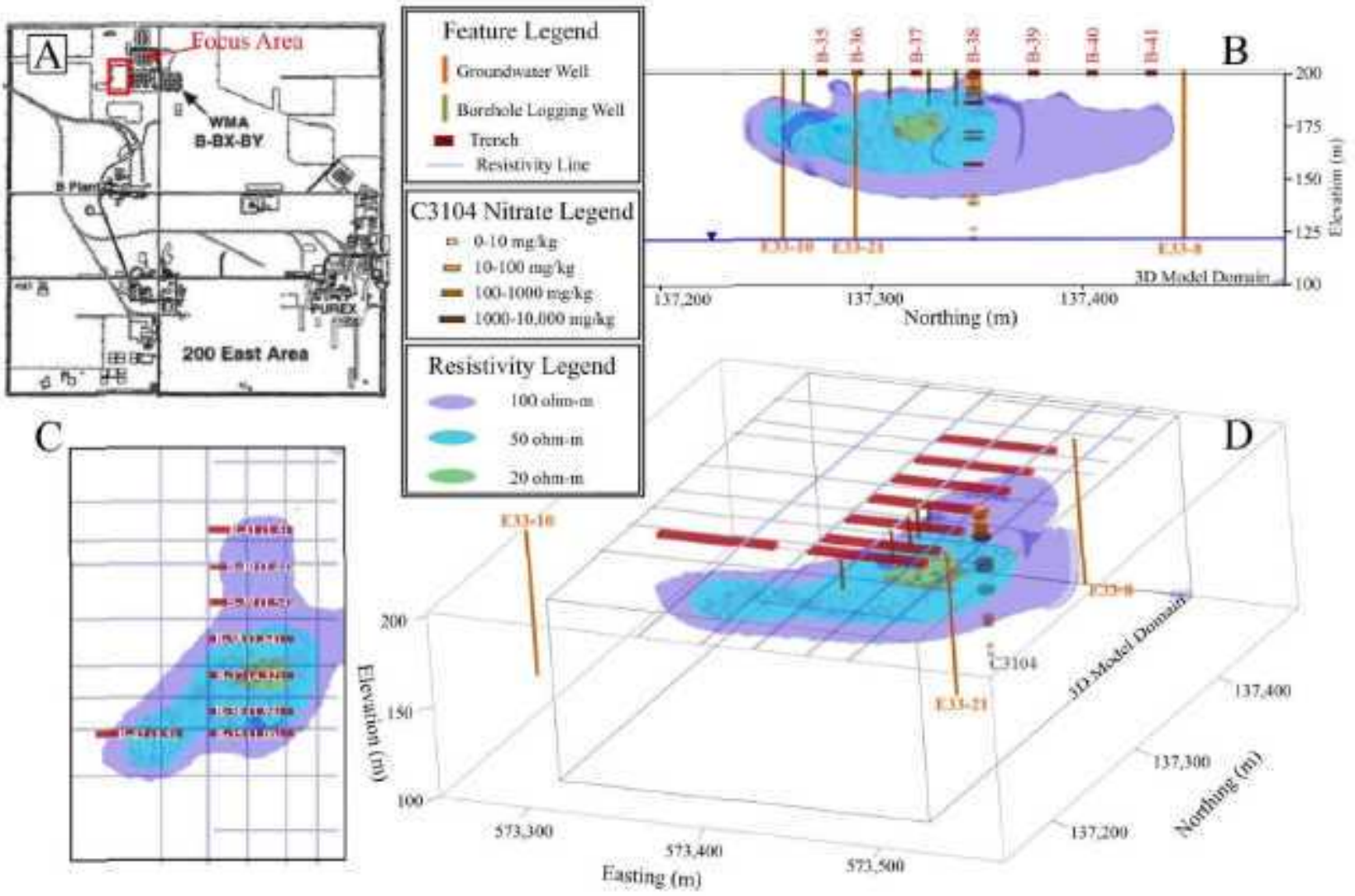

A) Site location with 200 East Ares of Hanford. B) Side view looking east of the electrical resistivity distribution underneath the trenches, showing three transparent isopleths of increasing values. Cj Overhead view of the resistivity distribution, with disposal volumes in parentheses indicated as millions of liters. D) 3D isometric view of the resistivity distribution.

Another way of evaluating the resistivity data is to consider what value the analyses of the data have in reducing the uncertainty in understanding the spread of contamination. As opposed to classical statistics of confirming or denying hypotheses (such as whether the resistivity exactly matches borehole data), Bayesian methods use the additional information from geophysical characterization to update prior knowledge. Many have used the Bayesian framework to reduce the uncertainty across a number of sites (e.g., Ezzedine et al., 1999, "Bayesian Method for Hydrogeological Site Characterization Using Borehole and Geophysical Survey Data: Theory and Application to The Lawrence Livermore National Laboratory Superfund Site" and Chen et al., 2001, "Estimating the Hydraulic Conductivity at the South Oyster Site from Geophysical Tomographic Data Using Bayesian Techniques Based on the Normal Linear Regression Model") even in the face of weak relationships between the borehole and geophysical data. This weakness is typically a result of a scale mismatch between a geophysical value representing a large volume of the earth $(10$ s of cubic meters) and borehole samples representing a small volume (10s of cubic centimeters), as well as other issues discussed in Rucker, 2010 and 
Singha and Moysey, 2006, "Accounting for Spatially Variable Resolution in Electrical Resistivity Tomography through Field-Scale Rock-Physics Relations". In the case of the BX trenches. the resistivity information could be used to reduce uncertainty in placing new bereholes for additional characterization or help design a remedial strategy. In the latter case, the resistivity data could be used to help focus conservative estimates of design parameters, since it is likely that the feature mapped by the resistivity technigue is focusing on the most conservative tracer (namely nitrate).

\subsection{MAPPING WASTE SITES WITH COMPLEX INFRASTRUICTURE}

By the 1970s. the use of electrical resistivity as a mineral prospecting tool had changed to consider many different engineering and geologically-based problems. The encroachment of survey lines for these applications into settled areas prompted several to consider the effects of existing veltical or horizontal conductors (pipes, cables, and wells) on the measured voltage data (e.g., Patella. 1983. "On the Relationship Belween Apparent Resistivity Functions in the Case of Complicated Underground Structures;" Wait, 1978, "Some Earth Resistivily Problems Involving Buried Cables;" and Wait and Umashankar, 1978, "Analysis of the Earth Resistivity Response of Buried Cables"). Using potential field theory, the solution was reduced to considering superposition. With superposition. nultiple solutions representing the fields from a number of different features are added together, such as the primary potentials $\left(V_{p}\right)$ for a background resistivity and secondary potential $\left(V_{s}\right)$ for any pipes. For the PP case, the total voltage field $\left(\mathrm{V}_{\mathrm{T}}\right)$ can be constructed for a pipe located perpeudicular to the survey line at a depth of $\mathrm{h}$, diameter of c. distance from curtent electrode equal to d, and infinitesimal resistivity (Wait and Umashankar. 1978):

$$
V_{T}=V_{p}+V_{s}
$$

where

$$
V_{p}=\frac{I \rho}{\pi^{2}} \int_{0}^{\infty} K_{0}\left[\lambda\left(x^{2}+y^{2}\right)^{1 / 2}\right] \cos \lambda z d \lambda=\frac{l \rho}{2 \pi\left(x^{2}+y^{2}+z^{2}\right)^{1 / 2}}
$$

and

$$
\begin{aligned}
& V_{s}=\frac{l \rho}{\pi^{2}} \int_{0}^{\infty} P(\lambda)\left\{K_{0}\left[\lambda\left[(x+h)^{2}+(y-d)^{2}\right]^{1 / 2}\right]+K_{b}\left[\lambda\left[(x-h)^{2}+(y-d)^{2}\right]^{1 / 2}\right]\right\} \cos \lambda z d z \\
& P(\lambda)=-\frac{K_{0}\left[\lambda\left(h^{2}+d^{2}\right)^{1 / 2}\right]}{K_{0}(\lambda c)+K_{0}(2 \lambda h)}
\end{aligned}
$$

In the Equations (10) through (12), $K_{6}$ is the modified Bessel function of order 0 and $x, y, z$ refer to the position of the voltage potential electrode relative to the current electrode. For more complicated cases of multiple parallel pipes. the solutions must further consider the effects of each secondary field and the interrelationships that the secondary fields have on nearby pipes, as 
demonstrated by Wait, 1978. An example is presented in Figure 15A, where two pipes spaced $20 \mathrm{~m}$ apart are located $0.5 \mathrm{~m}$ below ground surface and with a diameter of $0.15 \mathrm{~m}$.

The background resistivity is $400 \mathrm{ohm}-\mathrm{m}$ (value substituted for $\square$ in Equation [10]). The data are presented as a pseudosection of the apparent resistivity (resistivity data calculated by rearranging Equation (10), assuming that each measurement was conducted in a homogeneous earth). Diagonally at approximately $45^{\circ}$, low resistivity "pantlegs" extend below each pipe. At the intersection of the pantlegs (at $145 \mathrm{~m}$ along the line), the potential fields add constructively to form a very low resistivity value at a depth of about $10 \mathrm{~m}$. Any other information, such as an area of increased saturation or ionic strength, would likely be hidden in the signature of the pipes without much hope of recovery.

Figure 15. Examples of Metallic Infrastructure in Electrical Resistivity Images.

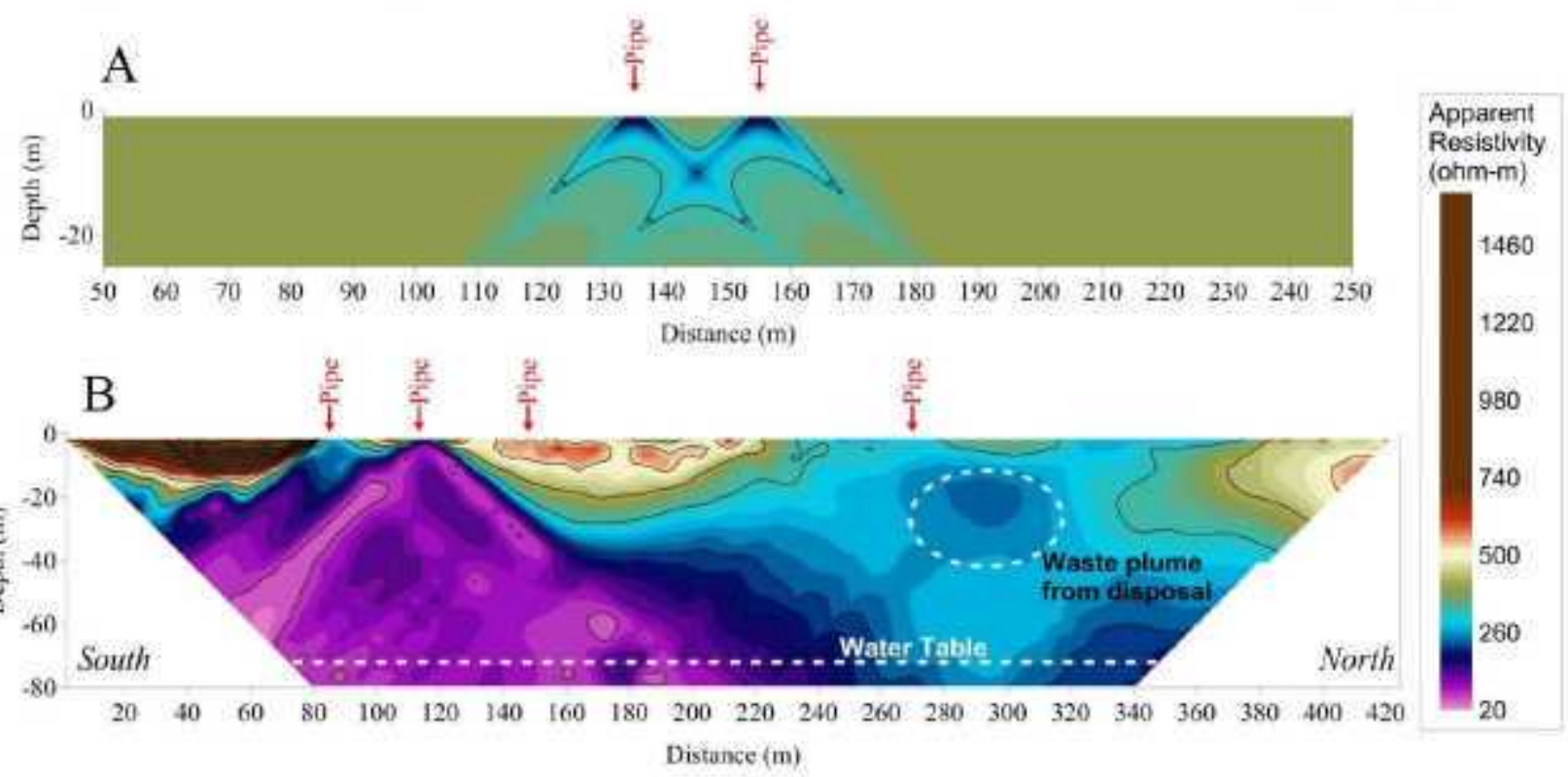

A) Analytical model of two nearby pipes showing the combined effects (i.e., constructive interference) from the overlapping fields. B) Data acquired along line 16E of the T tank farm (see Rucker et al, 2010) showing similar constructive interference effects from pipes, a water table, and a discharge of highly saline waste in a nearby trench.

\subsection{TANK FARM CHARACTERIZATION}

\subsubsection{Characterization with Wells as Long Electrodes}

After the successful acquisition of resistivity data at the BCCT, a series of parallel and orthogonal resistivity lines were completed over the $T$ tank farm, including placing lines directly through the farm and between the tanks. The project was described in Rucker et al, 2010. An example from line $16 \mathrm{E}$ of that project is presented in Figure $16 \mathrm{~B}$ to demonstrate the effects of infrastructure near a tank farm. The pipes are identified along the top of the figure. Below the pipes on the south side of the line, the resistivity values are very low. In addition to the pipes at the surface, other conductive features deeper in the profile, which add constructively to reduce the apparent resistivity of the section, include a water table and waste disposed in nearby 
trenches. Interestingly, some pipes do not appear to affect the data, likely due to the lack of coupling with the surrounding formation.

To overcome the infrastructure issue at the T tank farm. the large numbers of steel-cased wells were used as long electrodes. Most wells were completed in the vadose zone down to about 30 $\mathrm{m}$, but some extended to the water table. Additionally, most wells were concentrated in the tank farm, with fewer placed along the periphery. Hypothetical modeling suggested that wells could effectively see through the infrastructure by distributing some of the electrical curtent below it (Rucker et al., 2010). Additionally. the measured voltage at the bottom of the well is essentially the same as the top, avoiding intrastructure on the receiving end of the resistance measurements. The limitations of the method included: 1) a loss of vertical resolution since the plume could essentially be anywhere along the length of the well and provide the same measurements; and 2) a lateral coverage limitation based on the placenent of the wells. The consequence of low vertical resolution is that the method is difficult to validate with field data. The consequence of low lateral coverage is that sufficient background may not be acjuired to capture the edge of a target. Regardless, the conductive plumes reconstructed by the long electrode resistivity method at the $T$ tank farm matched expectations with regards to known disposal locations and anticipated plume trajectory. Confirmatory work with the long electrode method was also conducted in waste sites outside of the tank farm with $3 \mathrm{D}$ surface resistivity; those results showed that the long electrode method worked well as a simple tagget recognition tool (Rucker et al, 2010).

The $C$ tank farm project was conducted as a test case to overcome resolution limitations from the T tank farm project. Lateral coverage was increased by adding surface-based point electrodes along the periphery of the farm in areas thought to be unencumbered by infrastructure. Initial modeling using electrodes on the surface and few wells in the center of the domain suggested that the surface electrodes were as effective as long electrodes. Additionally, the models were able to discriminate between shallow and deep targets. Figure $16 \mathrm{~A}$ shows the results of a resistjvity model used to image either a shallow target located from 10 to $15 \mathrm{~m}$ below ground surface with a resistivity of $1 \mathrm{ohm}-\mathrm{m}$ (background of $100 \mathrm{ohm}-\mathrm{m}$ ), or a deep target from $60-65 \mathrm{~m}$ below ground sutface (below the bottom of the wells at $44 \mathrm{~m}$ ). The models are conceptually sinilar to those presented in Rucker et al.. 2010. The results of the shallow target are shown to have the lowest resistivity signature at the surface. The results of the deep target are shown to be at a centralized depth of aboul $40 \mathrm{~m}$.

The electrical resistivity survey at the $C$ tank farm included measurements from 69 wells completed in the vadose zone, 8 groundwater wells, aud 188 surface electrodes placed along four lines on the outside of the tank farm fence line. The PP array generated approximately 23.800 data values for inclusion in the inverse model. The surface electrotes were decimated to $25 \%$ to reduce the model's complexity. The results, shown as Figures $16 \mathrm{~B}$ and $16 \mathrm{C}$. highlight low resistivity areas that are likely indicative of high jonic strength porewater. Figure $16 \mathrm{~B}$ is a contour plot of the uppermost layer of the model (at $0.5 \mathrm{~m}$ depth) and shows the lowest resistivity coincident with tank C.-101. Several other smaller targets are identified south of $\mathrm{C}-103$, west of $\mathrm{C}-107$, in and around C-105, and around UPR-82. The cuality of each target is affected by the size, intensity (i.e., resistivity contrast relative to background), and number of electrodes near the target. A tal'get of lowest quality would be one in which few electrodes (either wells or surface electrodes) exist nearby. such as the UPR-82 target. A low quality target would warrant further investigation. A high quality target would be one in which several nearby 
electrodes exist and all effectively confirm the presence of the target, such as that beneath C-101. Intermediate quality targets include south of $\mathrm{C}-103$, where two wells define the lowest resistivity portion of the target, and several more show a feature extending northward beneath the tank to the north side. The target to the west of C-107 is also of intermediate quality.

\section{Figure 16. Modeling Results For The C Tank Farm Using Both Long Electrodes (Wells) and Point Electrodes Along the Periphery of the Tank Farm.}

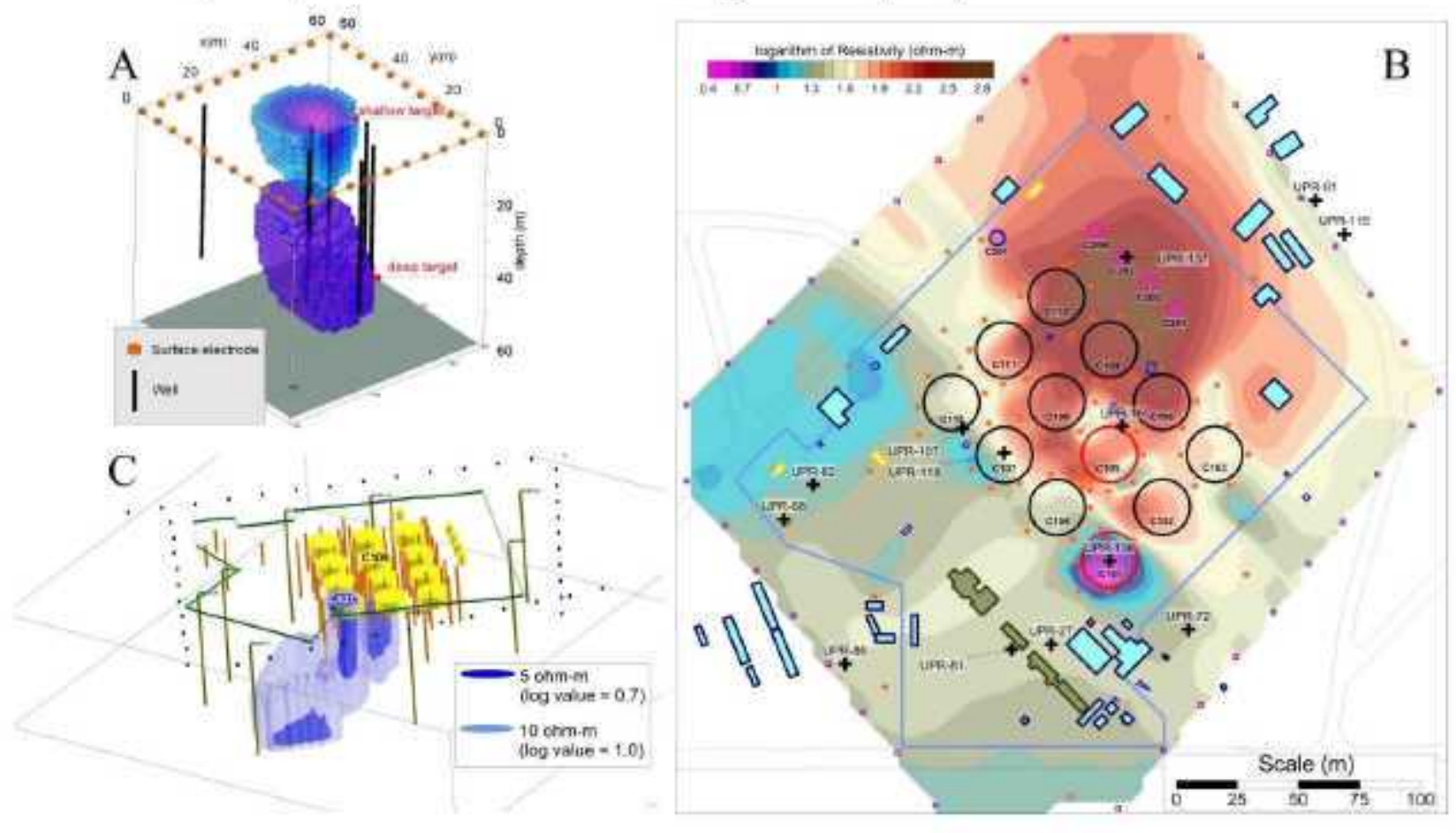

A) Example modeling showing the combination of wells and surface electrodes can be used to distinguish deep and shallow targets, B) Overhead plan view of the resistivity distribution of the uppermost layer (at $0.5 \mathrm{~m}$ ). For feature legend, consult Figure 1. C) Isometric 3D view of low resistivity targets, showing an elongated feature from tank C-101 that may be contributing to groundwater contamination.

A 3D perspective of the most conductive data within the model's domain is provided in Figure 5C. This figure provides a view towards the northwest from the southeast and shows two isopleths representing 5 and $10 \mathrm{ohm}-\mathrm{m}$ for the small opaque and large transparent targets, respectively. The feature beneath $\mathrm{C}-101$ appears to extend deeply beneath the tank and spread to the southwest in the direction of groundwater flow. The groundwater wells in the southwest portion of the site have seen increased nitrate and technetium concentrations over the past several years (RPP-RPT-48490, Technical Approach and Scope for Flow and Contaminant Transport Analysis in the Initial Performance Assessment of Waste Management Area C). All other targets shown in Figure 16B are not apparent in Figure $16 \mathrm{C}$ due to the low resistivity values presented in Figure 16C. Maximum resistivity values at the targets near C-103 and C-107 are approximately 20 ohm-m.

A secondary deeper resistivity target can also be seen beneath C-108 in the Figure 16C. Interestingly, the $\mathrm{C}-108$ target does not appear to have a similar connection to the surface like 
that of C-101 and the origin of the anomaly is unknown. The resistivity feature also appears to be located below the depth of local dry wells.

In the time after the $\mathrm{C}$ farm project. the size of the resistivity surveys increased based on the advancement in both computer hardwase and inversion software. For hardware. the internal memory increased significantly to allow greater domains to be modeled, and the number of processors increased for greater speed. The inversion software was modified to accommodate both aspects of hardware changes, including parallel processing capabilities. As a result, B, BX, and BY tank farms were imaged together. covering an area of approximately 54 ha with 36 surface lines (totaling approximately 25 line kilometers of lineal coverage) and 224 wells. The TX and TY farms were also imaged toyether with 44 surface lines and 162 wells over an area of $46 \mathrm{ha}$. Increasing the areal extent of the survey also allowed the first look at the complex dynamics of coniugled plumes from inside (due to tank leaks) and outside (fron direct disposal to trenches and cribs) the tank farm. As such. this capability allowed a more holistic assessment not bound by contractor or regulatory constraints.

The work in and around tank farms also had another change in strategy in that the electrodes were left behind for permanent placenent (Rucker et al, 2008. "Development of an Electrical Resistivity Imaging Program for Subsurface Characterization at Hanford"). The TX and TY project left approximately 4,500 electrotes around the site. The advantage of the permanent electrodes is the ability to conduct time lapse analysis by reoccupying the stations. These data can then be used to assess new sources to groundwater contamination or verification of risk models that predict long-term behavior of known plumes.

\subsubsection{Characterization with Buried Electrodes}

Advancements in vertical resolution of resistivity targets in tank farms have been achieved through the use of borehole electrodes. The idea of using borehole electrodes is not new. especially at Hanford (e.g., Johoson et al., 2010. "Improved Hydrogeophysical Characterization and Monitoring through Parallel Modeling and Inversion of Time-Domain Resistivity and Induced-Polarization Data"). but getting them in a tank farm was seen as a logistical challenge due to the expense of drilling. To overcome this, the electrodes are placed at depth through the drive casing of the newer direct push rig. Initially, one borehole electrode was placed in each direct push hole. as the borebole was decommissioned. Later, designs changed to allow two electrodes to be placed in a hole. with one consisting of an electrode at the bottom of the hole. and another lowered to a desired depth within the casing. Limitations for additional electrodes were based on the tinite internal diameler of the drive casing: there was no more room for additional wires and electrodes and still be able to decommission the hole appropriately. The solution was to construct a nulti-conductor cable with steel braid tubing on the outside of the cable to act as the electrode. The maximum diameter of the cable was approximately one centimeter and 10 electrodes could be placed within a single hole along a single cable. Standard practice at the site is now to place cables at all push hole locations, in anticipation of occupying the stations for resistivity measurements in the future.

A test case for conducting a resistivity survey with many borehole electrodes includes the southwest corner of the BY farm (Figure 17A). The BY farm, consisting of 12 tanks each with a capacity of $3 \times 10^{6}$-L, was built fiom 1948 to 1949 . The tanks were filled with several types of 
wastes: metal waste, first-cycle decontamination waste, tributyl phosphate waste, and evaporator feed and bottoms waste (RPP-RPT-43704, Hanford BY-Farm Leak Assessments Report). Over the years, filling and emptying the tanks have resulted in UPRs; tank BY-103 was thought to have lost approximately $19 \times 10^{3}$ - L based on uncertainty in manual tape recordings for liquid level monitoring. Tank BY-107 was also thought to have lost $57 \times 10^{3}-\mathrm{L}$ based on liquid level monitoring. New evidence by RPP-RPT-43704 suggests that the use of the monitoring tape may have been flawed or that the release observed in nearby geophysical logging wells was actually the result of another UPR at the surface near BY-107 of approximately $87 \times 10^{3}-\mathrm{L}$. Lastly, the potential status of BY-108 as a leaker is in question due to the different possible sources of contamination, including a leaking tank at BY-107, a leak through a valve, or near surface piping. The impacts of the releases were first investigated with borehole geophysical logging. Figure 17B shows the interpolated distribution of cobolt- 60 around the tank farm. Cobalt- 60 has a low $\mathrm{k}_{\mathrm{d}}$ and the contaminant appears to have migrated to a depth of about $20 \mathrm{~m}$.

Figure 17. Three-Dimensional Resistivity of the BY Tank Farm.

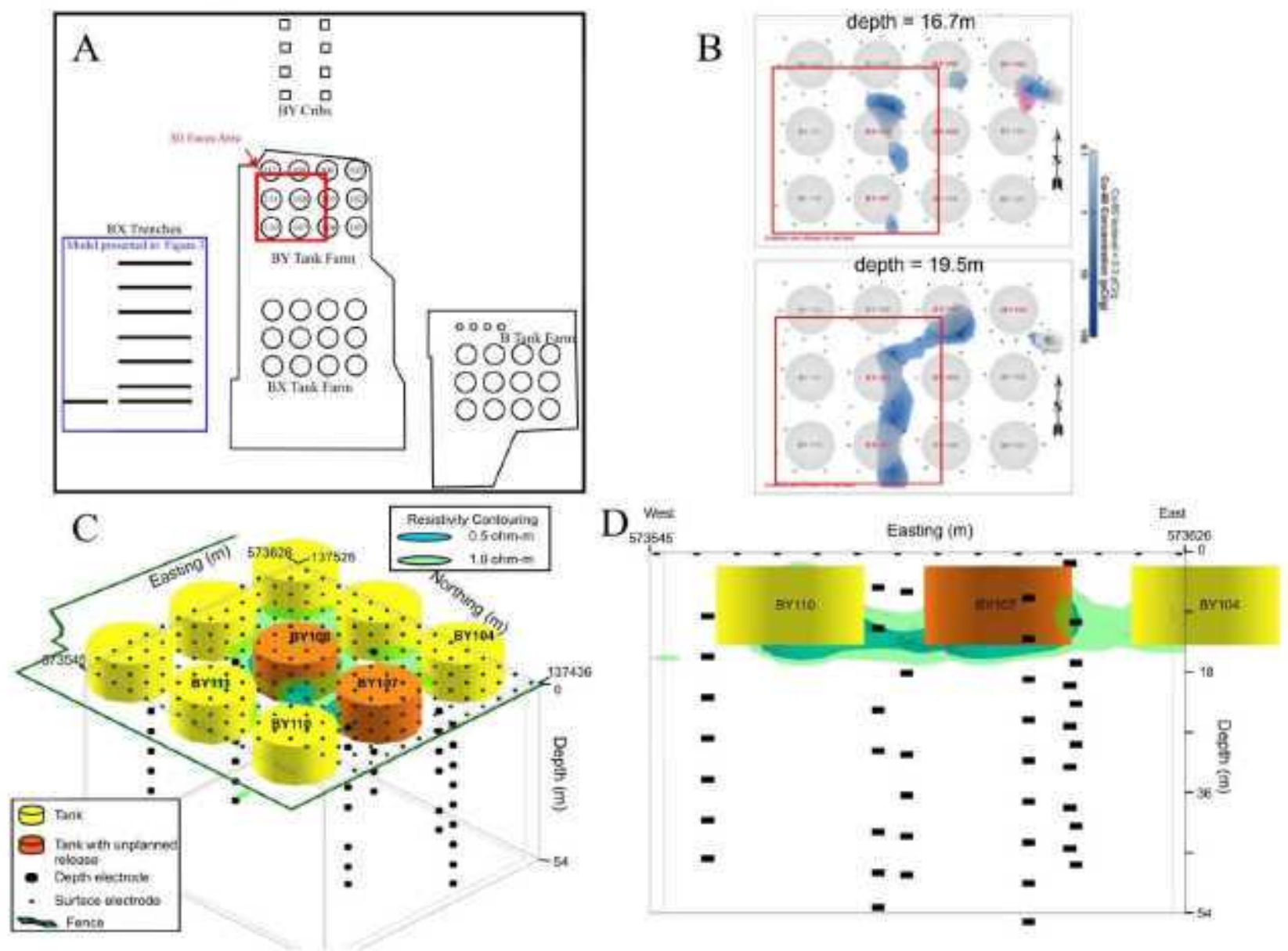

A) Site location relative to the model presented in Figure 15. B) Cobalt-60 contours at two depths, derived from spectral gamma borehole logging. C) Isometric view of the low resistivity plumes in the southwestem portion of BY Farm. D) Side view from the south showing the vertical distribution of electrical resistivity around the tanks. 
A dense coverage resistivity survey was conducted over the BY tank farm using a grid of 212 electrodes over an area of 78 by $90 \mathrm{~m}$. Additionally, 53 borehole electrodes were placed in seven direct push holes. The results of the inverse modeling of the data can be seen in Figures 17C and 17D. The figures show two resistivity isopleths of 0.5 and $1 \mathrm{hmm}$. The resistivity target appears to be on the east side of tanks BY-107 and BY-108, coincident with the cobalt plume. However, the resistivity data also mapped a feature to the west of these tanks, which is confiued on the west by the internal comers of BY-110 and BY-111. From a depth perspective. the resistivity target is within the top $18 \mathrm{~m}$, roughly equivalent to the cobalt plume shown in Figure 17B. Despite having been conducted from the surface above the infrastructure. the methot of acquisition seemed to reasonably seconstruct a resistivity anomaly among tanks. The upper layers of the model (not shown) had linear features that coincided with known pipe locations, but they did not appear to influeuce the deeper anomalies.

\subsection{TANK FARM LEAK MONITORING}

Traditional leak detection methods on the SSTs include spectral gamma and neutron logging in the nonitoriug wells, which are drilled near tanks to varying depths. Well logging can be an insensitive tool because of its limited sample volume and time to conduct the measurenuent. If a leak occurs, tank waste must first move through the soil to within less than a meter of the monitoring wells before showing a positive leak result. This process could take days or even weeks before the leak is detected. In an effort to monitor tank integrity and minimize the length of time before potential leaks are caught, an electrical geophysics monitoring program has been deployed on seven of the Hanford SSTs.

To validate the monitoring approach, a series of tank leaks were simulated in the S tank farm around tank S-102 to test the effectiveness of several resistivity based geophysical methods to quantify these leaks. Figure 18 shows the location of S Farm and the leak test. The leak injection system included the use of a dry well, originally designated as a leak detection monitoring well (located at the $100^{\circ}$ clock position around tank S-102). for injection of the tank waste simulant. The well was converted from a leak detection well to an injection well by perforating the 15 centimeter (cm) diameter carbon steel pipe from 15 to $33 \mathrm{~m}$ below ground surface and plugging the well below the perforated zone. The perforated zone was designed to simulate a leak from the tank bottom. The simulated waste consisted of a $25 \%$ (by volume. or 250,000 part per million [ppm]) sodium thiosulfate pentahydrate solution wilh a specific gravity of approximately 1.138 at a temperature of 23.1 degrees Celsius. The simulant had electrical properties similar to the radioactive waste stored in underground tanks, which was estimaled to be approximately $0.08 \mathrm{obm}-\mathrm{m}$. The electrical properties of the solution were not measured explicitly for this test. but estimated from tabulated values from Weast, 1986, CRC Handbook of Chemistry and Physics. Schön, 1998, Physical Properties of Recks - Fundamentals and Principles of Petrophysics also shows similar sodium compounds with equivaleut resistivity values. A series of ten simulated leaks occurred over a 3 month period with a total $51 \times 10^{3}-L$ of solution injected into the sub-surface.

Prior to the leaks, a long electrode electrical resistivity survey was conducted in the $S$ tank farm to establish a baseline condition for comparison with the post leak test condition. The survey included resistivity measureneuts on the steel-cased wells. The survey design. acquisition, and processing methodology was similar to the long electrode char acterization conducted by 
Rucker et al,, 2010 in the T tank farm, where the wells were used as both current transmission and voltage receiving electrodes. The PP configuration was used, and the remote electrodes were located approximately $1,500 \mathrm{~m}$ away in nearly opposite directions. The steel-cased monitoring wells were dispersed near the footprint of the northern tanks S-101 through S-106. The monitoring wells were typically less than $42 \mathrm{~m}$ in length, with the water table at approximately $70 \mathrm{~m}$ below ground surface.

Figure 18. The Location of the S Tank Farm Within 200 West and the Site of the Leak Injection Test.

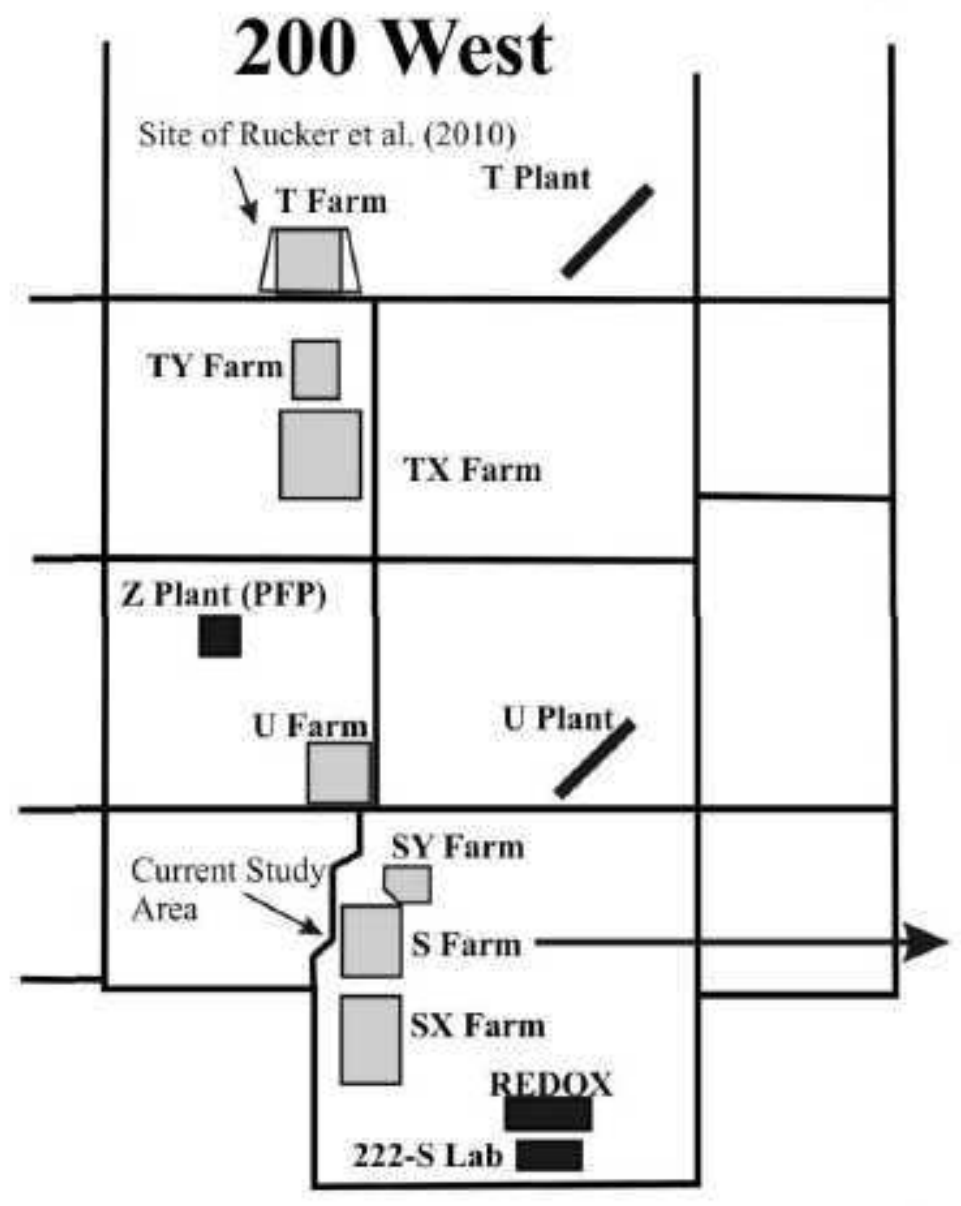

*For reference only, not to scale

\section{S Tank Farm}

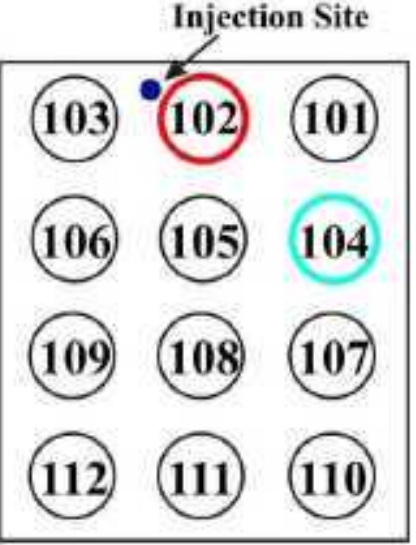

Site of Leak Injection Test

Historically Leaky Tank

One month after the cessation of the injection testing, a follow-on resistivity survey was completed on the same wells used in the pre-injection survey. Figure 19 shows the scatter of the measured data for the pre-and post-injection, with data presented as apparent resistivity. The apparent resistivity was calculated the same as if it were a point electrode on the surface. The pre-injection data in Figure 19A shows low scatter among reciprocal measurements, whereas the post-injection reciprocal measurements exhibited higher scatter. The reciprocal error was used as a means for data rejection, with those data outside the $5 \%$ range eliminated from the dataset. Of the 992 combinations, 46 were rejected for high reciprocal errors. Figure 
$19 \mathrm{C}$ shows the scatter of pre- to post-injection apparent resistivity data. The data within Figure $19 \mathrm{C}$ were used for inverse modeling.

Figure 19. Apparent Resistivity Data Acquired in the S Tank Farm Hanford Using Long Electrodes.
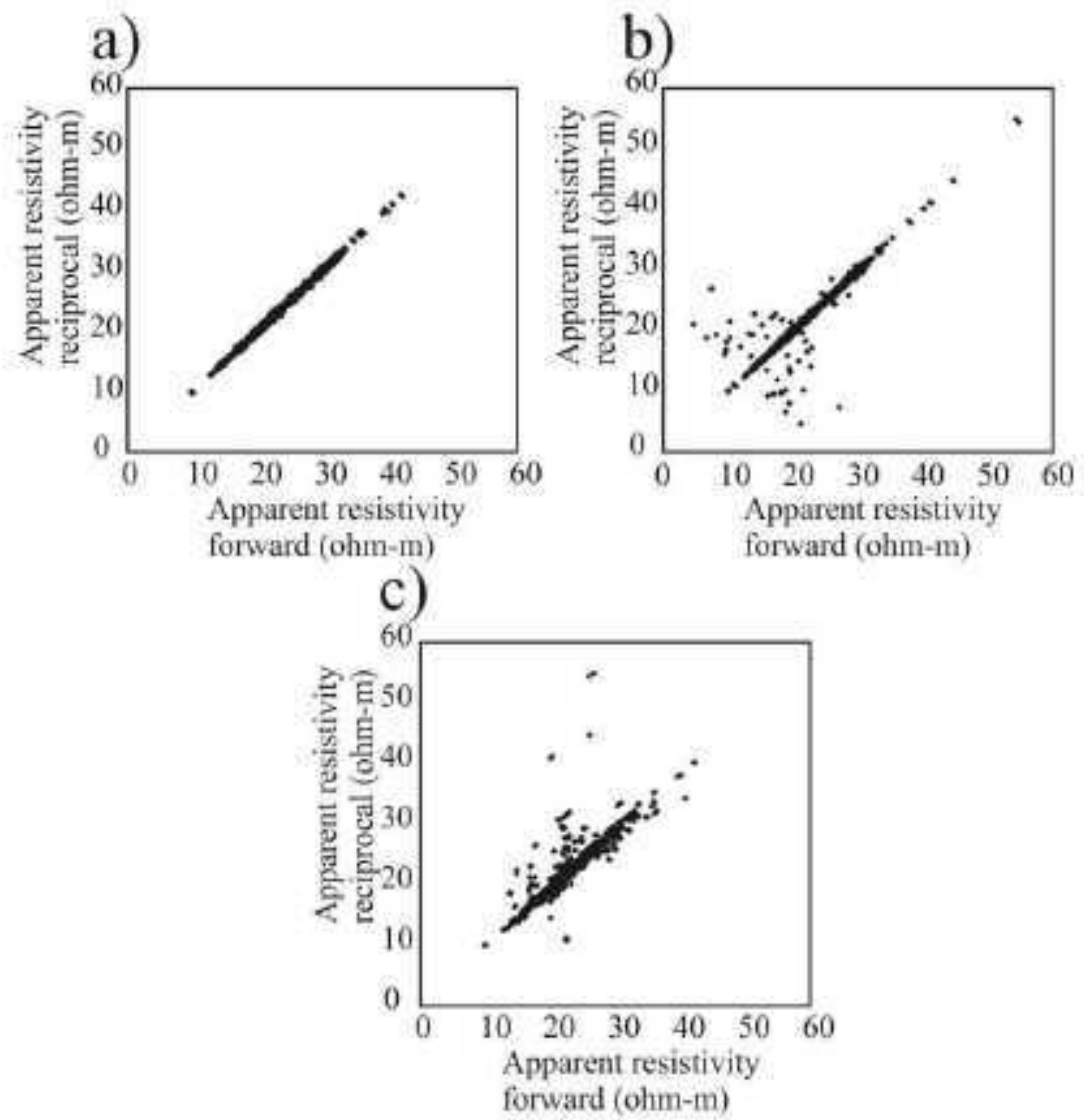

a) Reciprocal data scatter for pre injection survey, b) reciprocal data scatter for post injection survey, c) pre and post injection data seatter.

Figure 20 shows the results of the time-lapsed long electrode inversion of the $\mathrm{S}$ tank farm leak injection test. The top four models, Figures $20 \mathrm{~A}$ through D, show the logarithm of electrical resistivity for two snapshots of differing time-lapsed parameter values. Figures $20 \mathrm{~A}$ and $20 \mathrm{~B}$ represent the before and after leak injection test results with $\alpha=0.001$, and Figures $20 \mathrm{C}$ and $20 \mathrm{D}$ represent before and after with $\alpha=0.1$. In each figure, the lower left and right hand corners have been blanked to remove resistivity data. The blanking was based on the absence of wells in the area and the extremely low sensitivity of those cells to the final resistivity distribution.

The pre-injection results in Figures $20 \mathrm{~A}$ and $20 \mathrm{C}$ show a low resistivity target north of tank S104 and extending west-southwest across S-105. From historical characterization records and inventory reports, it is likely that tank S- 104 lost approximately $91 \times 10^{3}-\mathrm{L}$ of highly saline waste to the subsurface and the pre-injection assessment is mapping the footprint of the leak. Furthermore, the dipping subunits identified in the geologic assessment may be a driving force behind the westward migration. The post-injection results in Figures $20 \mathrm{~B}$ and $20 \mathrm{D}$ show a slight decrease in resistivity near the injection well (square symbol) at the northwest corner of S-102. 
Figure 20. Results of Time Lapsed Modeling of Long Electrode Data.
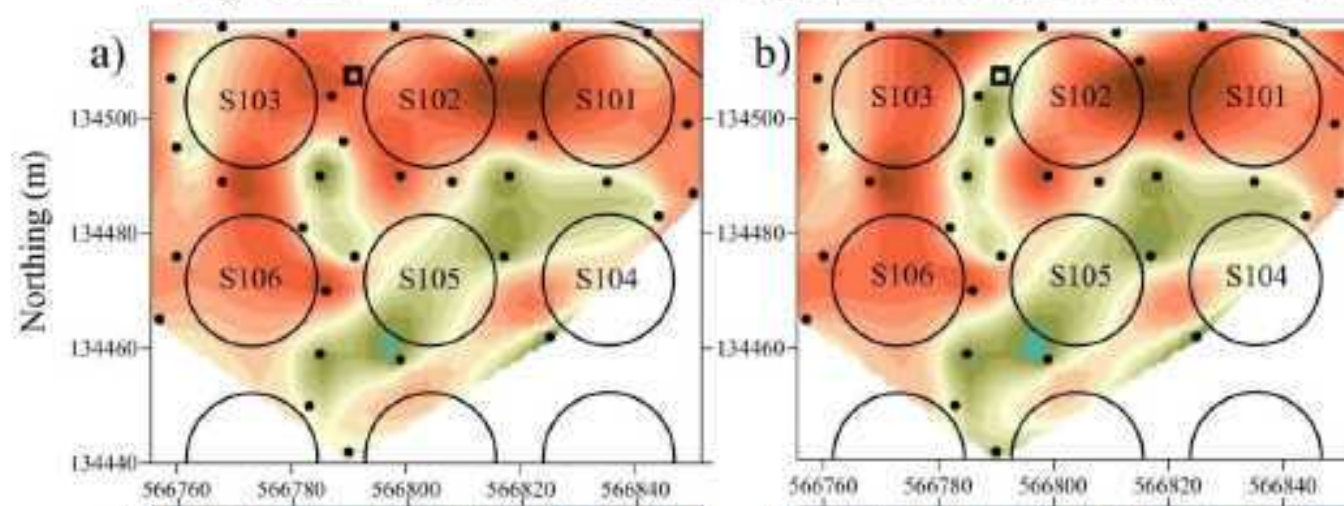

$\log$ Resistivity

(ohm-m)
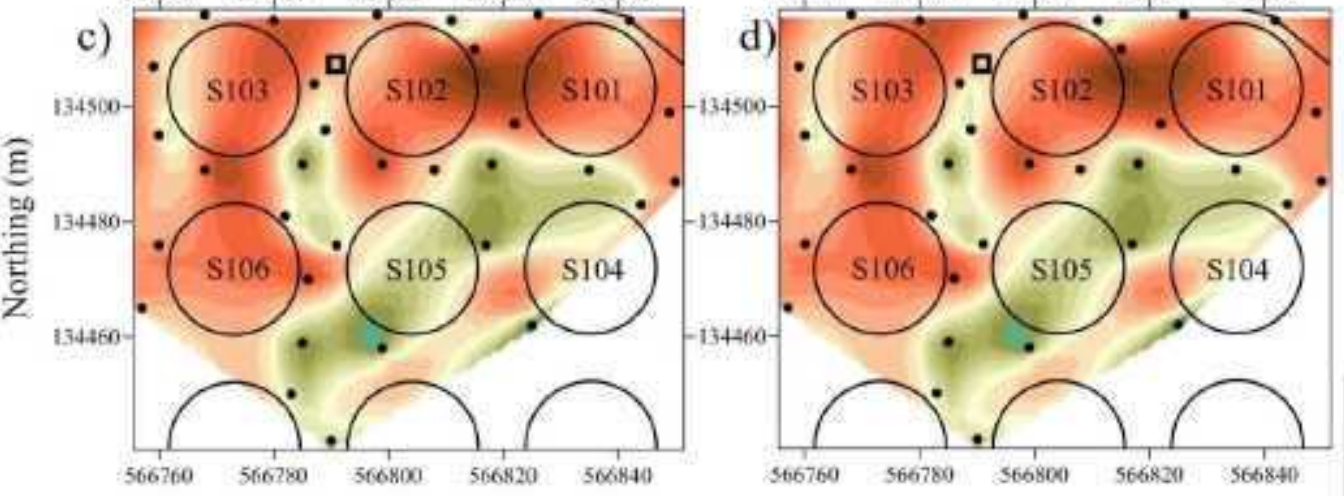

d)
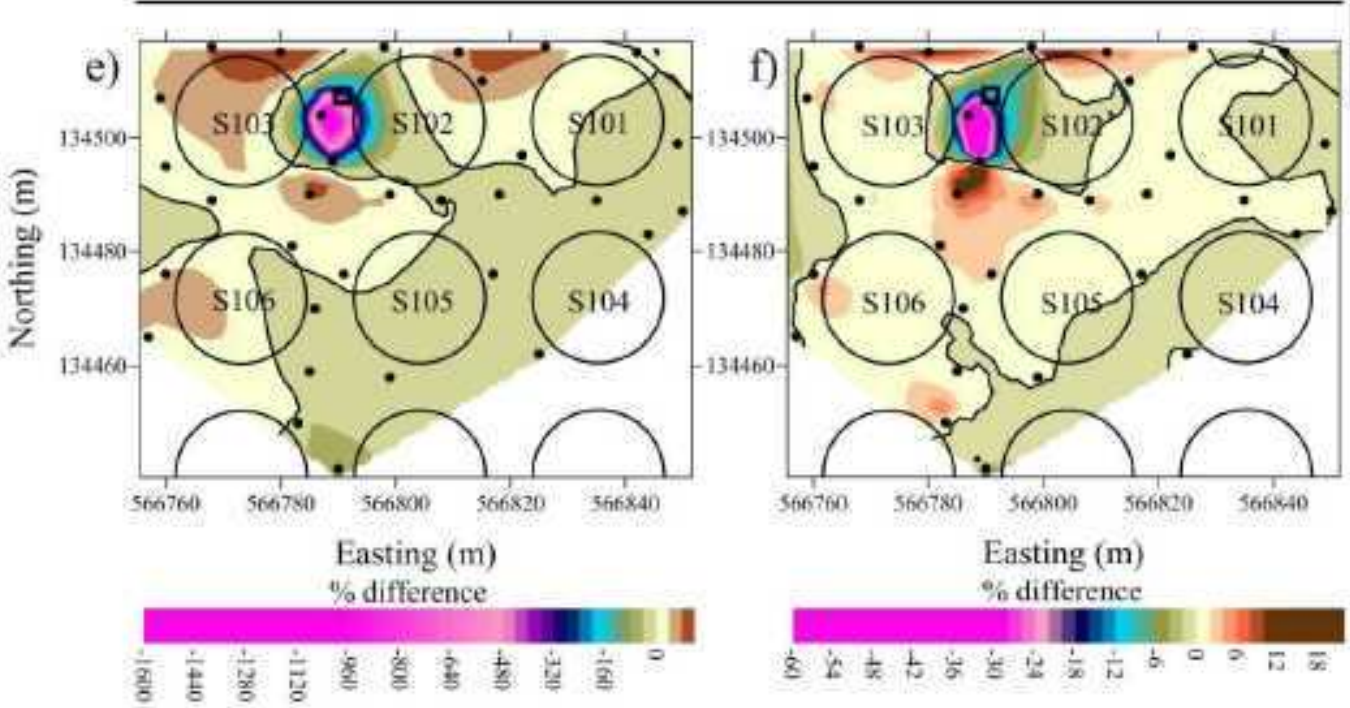

injection well tank footprint

a) Pre leak resistivity with $a=0.001$, b) post leak resistivity with $\alpha=0.001$, c) pre leak resistivity with $\alpha=0.1$, d) post leak resistivity with $\alpha=0,1$, e) peroent difference between pre and post for $\alpha=0,001$, f) percent difference for $\alpha=0.1$,

Note; The solid line in subplots $\mathrm{e}$ and $\mathrm{f}$ represent a percent resistivity change of zero.

The percent change in resistivity between pre- and post-injection surveys with $\alpha=0.001$ was more significant than $\alpha=0.1$, and Figures $10 \mathrm{E}$ and $10 \mathrm{~F}$ show these differences quantitatively. Both sets of models show a logical placement of the lowered resistivity near the injection well and both 
show a similar shape to the distribution of positive and negative changes (a percent change of zero is distinguished by a solid contour line). The similarity ends, however, with the intensity of those changes as indicated by the associated color scales. The smaller $\alpha$ parameter represented in Figure $10 \mathrm{E}$ shows that the scale of change was much greater than that associated with the larger $\alpha$ parameter.

Figure 21 shows the pre- and post-injection resistivity values for a model cell $8 \mathrm{~m}$ to the south of the injection well for a full range of $\alpha$ values. The lowest value for the modeling was zero, and was placed on the log scale plot as a matter of convenience. As $\alpha$ increases, the resistivity curves converge towards a single value (approximately $119 \mathrm{ohm}-\mathrm{m}$ ) and the percent difference between the pre- and post-injection model results nears zero. The time regularization appears to affect the pre-injection resistivity modeling much greater than the post-injection modeling at this cell. An inspection of behavior of different cells around the entire domain shows that the behavior can be wildly different for the shape of the pre- and post-injection curves, as they may change directions and cross as the $\alpha$ time-lapsed parameter increases. The common thread throughout the domain, however, is that the percent change in all cells tends toward zero as $\alpha$ increases.

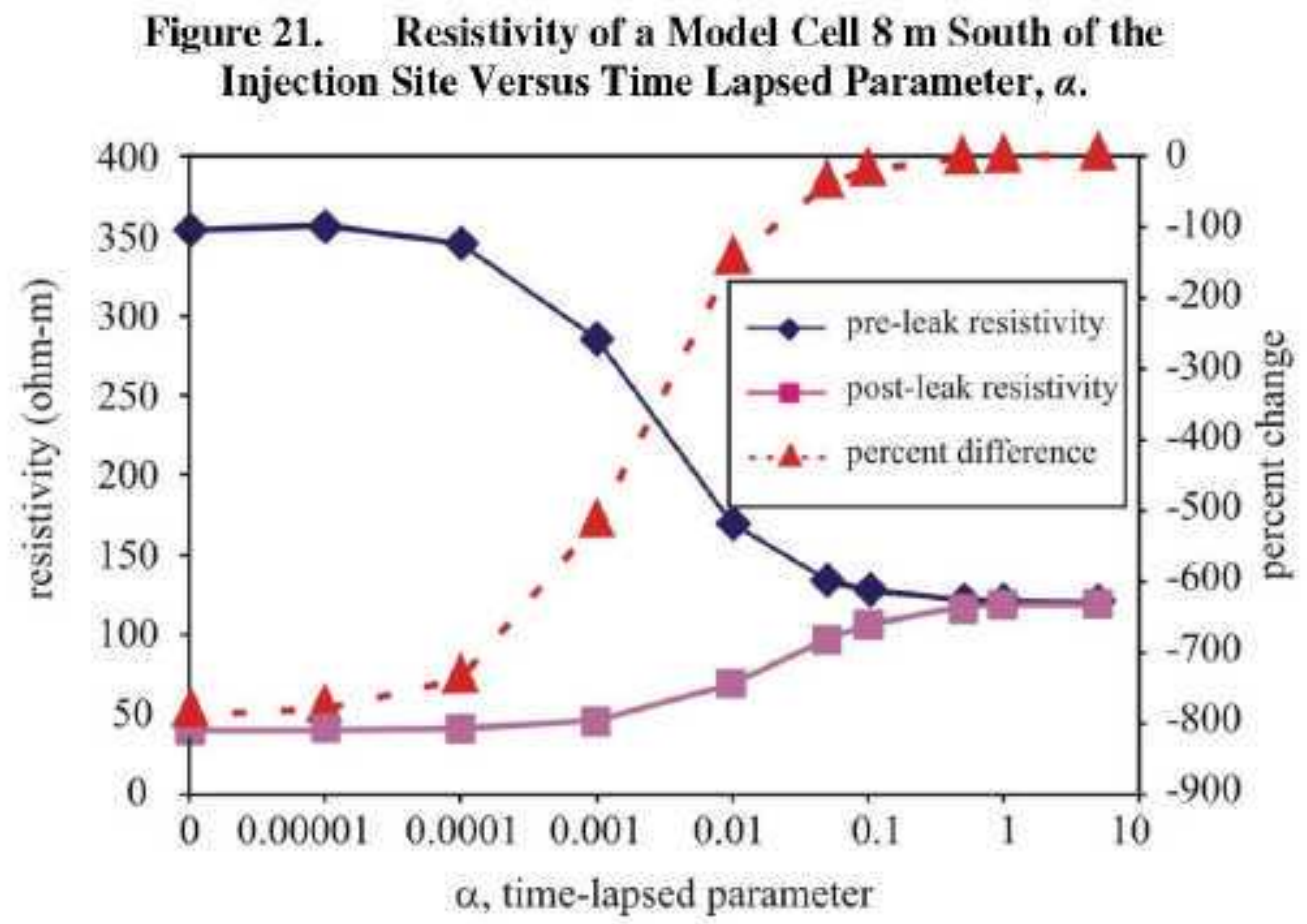

\subsection{SGE PROGRAM EVOLUTION}

As the use of electrical resistivity was advanced into areas originally considered too complex for the technology, changes were made to acquisition methodology, logistics, computer hardware, software, and interpretation that allowed robust images of electrolytic plumes in tank farms to be constructed. The evolution of the technology can be seen graphically in Figure 22. The first project conducted at BCCT showed that resistivity can be used to identify the extent of past 
releases at waste sites without infrastructure. The next leap came in the use of wells as long electrodes to avoid infrastructure in tank farms. By 2006, the method focused on increasing both spatial and temporal resolution; this latter aspect is presented in RPP-RPT-49129.

Figure 22. Evolutionary Time Scale of the Application of Resistivity at the Hanford Site. 2004

2005

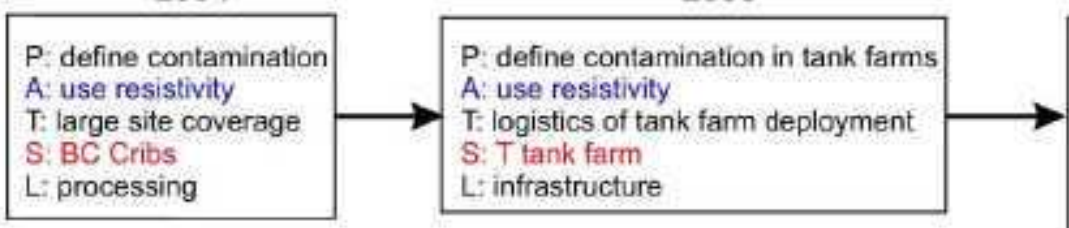

2007

\begin{tabular}{|l|}
\hline P: quality assurance \\
A: QA program that conforms \\
to DOE standards \\
T: procedures, testing, \\
equipment calibration \\
S: B Complex \\
\hline P: large site coverage \\
A. increase computing \\
capabilities \\
T: multi-threaded code \\
S: B, BX, BY farms (B Complex) \\
L: long inversion time
\end{tabular}

$P$ : quality assurance

QA program that conforms

equipment calibration

S: B Complex

L: long inversion time.
2006
P. temporal evolution of waste
A: time-lapse tomography
$T$ : $4 D$ long electrode tomography
S: S Fam
L: resolution
$P$ : lateral resolution
A: surface electrodes and wells in tomography
$T$ : increased coverage
S: C tank farm, $U$ tank farm
L: processing/vertical resolution

2006
2006

$P$ : infrastructure

A: use wells as electrodes

T: long electrode tomography

S: T tank farm

$\mathrm{L}$ : vertical and lateral resolution
2010

$P$ : Limited depth electrodes

A: developed 10 electrode string

T: greater coverage

S: SISX Farm, BY Farm, C Farm UPR-82
2007

P. vertical resolution from wells

A: borehole electrodes

$\mathrm{T}$. installation in drive casing of direct push

S: C Farm, B Complex

L: one electrode, limited coverage

$$
\mathrm{P}=\text { Problem Statement }
$$

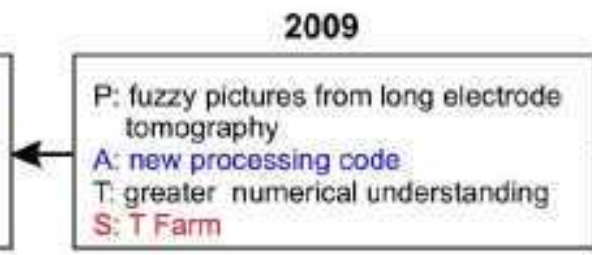

2009

2009

$P$ : single depth electrode

A: 2 electrodes in direct push

$T$ : increased coverage of borehole electrodes

S: C Fam UPR-81

L: low density coverage of site

$A=$ Answer $\quad T=$ Technology Development

$P$ : high resolution resistivity in C Farm A. 3D electrode grid

T: increased coverage of surface electrodes

S: C Farm UPR-81

$S=$ Site $\quad L=$ Limitations

Since late 2007, the acquisition advancements have been made in terms of getting more point electrodes beneath the infrastructure in tank farms. This endeavor initially started as a single electrode in a direct push hole but has since evolved to have 10 electrodes in a single hole, with up to seven borehole arrays being used in a relatively small area. Recent work has focused on understanding the longevity of the materials used for the borehole electrodes and how the installation process can be improved to increase the life expectancy of the electrodes.

On the software side, a major advancement was made in 2009 with the RES3DINVx64 inversion modeling code that has provided higher numerical accuracy when using long electrodes. In light of these new software advances, the older data are being revisited to update the resistivity models. 


\subsection{QUALITY ASSURANCE}

Since 2007, with the further refinement of a quality assurance (QA) program that fully conforms to DOE guidance, geophysics is being accepted as a defensible characterization tool for Hauford. QA is an important aspect to programmatic tectoology development for any government site. To this end, many procedures have been developed to ensure that the information prescribing layout of sensors, measurement strategies, software enhancements, aud storage of data are recoverable. Specifically, the collection and analysis of resistivity data are performed under a project-specific QA plan that conforms to requirements for nuclear facilities (ASME NQA-1, 2000, Qualiry Assurance. Requirements for Nuclear Facility Applications) and the DOE order (DOE $0414.1 \mathrm{C}$, Quality Assurance). Work not covered in the QA plan is consistent with accepted industry standards for geophysical methodologies and sound engineeriug principles. In addition, a project specific software management plan was prepared under similar guidelines.

The QA plan implements the following:

- Organization (Requirement 1)

- Quality Assurance Program (Requirement 2)

- Instructions, Procedures, and Drawings (Requirement 5)

- Document Control (Rejuirement 6)

- Corrective Action (Requirement 16)

- Quality Assurance Records (Requirement 17).

Columbia Energy and HGI collect data using designed systems or off-the-shelf commercially ayailable hardware. Designed systems conform to applicable requirements in approved procedures that address design, design analysis. design verification, and engineering drawing.

A project specific software managenent plan, CEES-0338. Sofhure Managenent Flant for Surface Geophysical Exploration Projects. was prepared to implement a graded approach to software mantagement in accordance with the following requirements documents:

- $\quad$ ASME NQA-1, Subpatt 2.7, "Quality Assurance Requirements for Computer Software for Nuclear Facility Applications"

- CEES-0333. Quatity Assurance Plan for Surface Geophysical Exptoration Projects

- CE-ES-3.5, Software Enginteering

- Coutract 28090, High Resolution Resistivity Characterization of Single Shell Tank Farm Waste Management Areas

- DOE O 414.1C. Quality Assurance.

\subsubsection{CALIBRATION AND MAINTENANCE OF EQUIPMENT AND INSTRUMENTS}

Calibration and maintenance of equipment used for data collection is addressed in CEES-0360. Where periodic calibration and/or maintenance of instruments used to collect quality atfecting data is recommended those instruments were current on calibration at the time the instrument was used for data collection and the calibration certificate is maintained in the project files. 
Field notes are used to document the specific instruments used. Electronic logs are utilized to provide traceable documentation for each data set collected. Information recorded in the electronic field log includes date, instrument identificatiou. operator, aud applicable settings for each data set collected. All instruments have curent calibration certiticates and documentation are maintained in the project files. Instrument calibration frequency and calibration tests performed in the field are documented in the system design description (CEES-0360).

\subsubsection{DATA COLLECTION}

The setup, operation, and maintenance of the SGE equipment used in collecting and analyzing resistivity data is described in CEES-0360. This document identifies the requirenents for the hardware and software used for data collection and analysis and provides a rationale for the hardware and software selected for use.

Calibration requirements are described for hardware used to collect geophysical data. As au example. the manufacturer (Advanced Gensciences. Inc.) of the resistivity data acquisition instrument (Supersting $\mathrm{R}^{\mathbf{1}}$ ) recommends a yearly calibration of internal calibration resistors. The calibration is performed at the manufacturer's facility and a certificate of calibration is provided. A copy of the calibration documentation, serial numbers, and expiration dates are maintained in project files.

In addition, dajly inspection of the receiver calibration is performed onsite using the manufacturer-supplied calibration resistor test box. The supplied test box is connected to the SuperSting R8 before commencing the daily survey. A specific calibration test firmoware is provided within the SuperSting and provides the operator with a pass/fail indication for each of the eight receiver channels. If any of the channels fail. a recalibration or repair is required.

In addition to calibration checks, data accuracy will be evaluated by performing reciprocal data collection for the A/AX WTW data collection efforts. Reciprocal collection is used as a tool to assure the data collected is accurate and repeatable. The transfer. storage. and management of data collected in the field are described in the system design description (CEES-0360).

\subsubsection{ELECTRICAL INTERFERENCE MONITORING}

Electrical interference can affect resistivity measurements in two ways: (1) grounded conductive infrastructure (pipes, tanks, tences) may provide a preferential current pathway that distorts predictable curent flow paths within the earth and (2) electrical noise (voltage/current) sources from electrical systems (cathodic protection, pumps, motors, earth grounding arrays, etc.) nay inject a competing signal. Electrical noise interference can be minimized by identifying noise sources and then turning off electrical sources where possible for the duration of the resistivity surveying.

A passive monitoring system is used to detect and map possible electrical boise interference prior to the start of resistivity measurements for any project. The electrical interference survey consists of temporarily wiring several electrodes or steel-cased monitoring wells, distributed over a tank farm (inside and outside of the farm fence), to a distribution panel. A digital recording.

\footnotetext{
- SuperSting RB is a registered trademark of Advanced Geosciences, Inc.
} 
oscilloscope is connected at the electrode measuring points (two at a time) and the background electrical field is digitally recorded via a laptop computer. The oscilloscope operates via the universal serial bus (USB) port on the laptop computer and does not transmit signal into the ground. Data is recorded before and after electrical systems are turned off to verify the reduction in electrical interference. The data is then assessed at an offsite location and recommendations to minimize electrical interference are made. The electrical interference survey is designed to identify the magnitude. frequency. and cycle time of possib]e interference.

\subsubsection{DATA PROCESSING}

The process used to filter the raw data is described in the system design description (CEES-0360). Data are downloaded from the resistivity instrument and parsed into a usable format. Data filtering technicjues are then used to remove data spikes or anomalous data caused by data acquisition card instabilities, or extraneous curent sources.

Data filtering is petfomed by copying the parsed raw data into an Excel data filtering tenplate that contains a series of graphs that show the various data parameters. The process of filtering eliminates data points, but no data modification (rounding, averagins, smoothing, or splining) is permitted. The rationale is to seek out and remove spurious points that do not contom to the data population or points that violate potential theory.

The final step is to inverse model the measured data to obtain the spatio-temporal distribution of electrical resistivity. Inverse modeling is accomplished using either EarthImager3DCL (EI3DCL) or RES3DINVx64 (RES3D). Verification and testing of the inversion software was performed and documented in (RPP-34974-2007, Veriffotion and Testing of the Earthimager Series of Electrical Resistivity Inversion Codes - A Benchmark Comparison). Additional validation of the long electrode technique was presented in Section 3.0 of this report.

\subsection{FUTURE POSSIBILITIES}

The mapping of contaminant plumes beneath the discharge sites is inherently a hydrogeological problem. It seems natural, therefore, to apply joint hydro-geophysical models that aim to correctly reconstruct parameters from both bydrogeological and geophysical disciplines. In order for this to happen, constitutive relations that tie the electrical resistivity parameter to a hydrological state variable (moisture content, ionic strength of porewater, etc.) need to be developed. One simple step towards integrating this information is to peiform joint laboratory measurements at a very basic level that can then be applied toward the overall inversion modeling. This is a difficult proposition given the range of resolution and sensitivity of the images derived from the various electrode types.

Another future prospect is the long-term mowitoring of tank farms after closure. The electrodes are already in place and time lapse measurements could be taken to ensure the performance of mitigating technologies such as surface recharge barriers or grouting of the tanks. The $\mathrm{S}$ farm leak injection test presented above denonstrated that the technique is capable of mapping the leaks. The tine lapse analysis could also be used to track existing plumes to gain a better understanding of the risk they may pose to groundwater. Time lapse analysis could also be 
applied to short-1erm remediation efforts of plumes beneath the cribs and trenches (PNNL-20209, Implementation Plan for the Deep Vadose Zone-Applied Field Research Center).

Lastly, several other DOE sites offer suitable environments for geophysical characterization. These sites were jdentified by their similarity to Hanford with regard to the type of liquid waste released to the vadose zone and to the quantities released such that they are likely to provide contrasts in electrical properties relative to the background. At Los Alamos, the canyons and mesas offer a perfect opportunity to help identify the footprint. source. and potential pathways of plumes resulting from disposal activities. The subsurface disposal area at the Idabo National Laboratory may also prove 10 be an area suited for geophysical characterization. The Savannah River Site has several aging tank tarms where resistivity may be applied in tank integrity investigations.

\subsection{CONLCUSIONS}

Over the past 60 years, the Hanford Site has discharged significant quantities of electrolyte enhanced waste into the vadose zone. The waste is comprised mostly of nitrate, sulfate, and phosphate ions with considerable inventories of radiological and heavy metal constituents. The results of the discharges have created large groundwater plumes that may, over the long term, threaten the Columbia River.

Understanding and characterizing the sources of these plumes will provide the basis to mitigate against future lisk through placement of various flow barriers, whether physical (Khalee] et al. 2007) or hydrological (Oostrom et al., 2009. "Desiccation of Unsaturated Porous Media: Intermediate-Scale Experiments and Numerical Simulation"). The waste sites at Hanford, unfortunately, are difficult to characterize due to the obstructions posed by different types of infrastructue. Pipelines, tanks, buildings, and other large features limit the ability to directy sample the subsufface and sone sites may not bave a suitable conceptual model to explain recent trends in monitored data. Such is the case for the C. tank farm. where down gradient groundwater wells are seeing a continued increase in nitrate and technetium concentrations (RPP-RPT-48490). The source of this contamination may be from one of the known UPR sites near diversion boxes, beueath tanks that have leaked, from overlying tansfer pipelines, an unrecognized release. or a combination of the se elements. Regardless, an accepted closure plan for the tank farm partially depends on adequately modeling the releases and historymatching observed trends.

To assist in the effort, an innovative geophysically-based characterization program has been developed to map the extent of releases beneath the tank farms. Based on the electrical resistivity method, the program has evolved over the past seven years to create robust 3D representations of the electrically conductive waste. The evolution has focused on the logistics of deployment in hazardous areas, acquisition with different types of electrodes (including point electrodes on the surface and withiu boreholes, as well as long electrodes from steel-cased wells), and iuverse modeling with highly accurate numerical schemes and nulti-threaded algorithms. A few of the projects were showcased above to highlight the asvancements, understand the limitations, and provide guidance on possible future directions of the technology. 
In particular, the $C$ tank farm indicated a massive low resistivity body directly beneath the $C$ - 101 tank that may be contributing to the observed increases in groundwater contanination. In the end the successful napping of these plumes can be attributed to the program management and allowing the science to evolve naturally.

The next step in the logical progression of the technology would be to move from characterization to long-term monitoring, where nultiple snapshots collected over tine could be compared to baseline conditions to assess changes. Given that most tank farms have permanent electrodes installed. additional equipment requirements are minimal. Snapshots could be taken at time intervals that capture the relevant dynamics of the system. such as once per year for newer leaks or every five years for older ones, as well as on demand as site requirements or local information changes. The data could then be used to verify conpliance issues outlined in the latest consent decree between the DOE, Environmental Protection Agency (EPA), and Stale of Washington.

\subsection{REFERENCES}

Alumbaugh, D.L., and G.A. Newman, 2000, "Image Appraisal for 2-D and 3-D Electronagnetic Inversion." Geophysics 65:1455-1467.

ASME NQA-1. 2000. Quality Assurance Requirements for Nuclear Facility Applications, American National Standards Institute/American Society of Mechanical Engineers, New Yotk, New Yotk.

Baker, V.R. and R.C. Bunker, 1985, "Cataclysmic Late Pleistocene Flooding fron Glacial Lake Missoula: A Review." Quat. Sci. Rev, 4:1-41.

Baker, V.R., B.N. Bjornstad, A.J. Busacca, K.R. Fecht, E.P. Kiver, U.L. Moody, J.G. Rigby, D.F. Stradling, and A.M. Tallnan, 1991, "Quaternary Geology of the Columbia Plateau," Quatevtary Nonglacial Geology; Conterminous U.S. Vol. K-2. R.B. Morison. ed.. Geological Society of America. Boulder, Colorado. pp. 215-250.

BHI-00184, 1995, Miocene- to Phocene-Aged Suprabasalt Sediments of the Hanford Site, South-Central washington. Rev, 00, Bechtel Hanford. Inc.. Richland, Washington.

Bjomstad. Bruce N.. Karl R. Fecht. and Christopher J. PJuhar, 2001, "Long History of Pre-Wisconsin, Ice Age Cataclysmic Floods: Evidence from Southeastern Washington Stale." Journal of Geology 109(6);695.713.

Calendine, S., D.F. Rucker. J.B. Fiuk. M.T. Levitt, and J. Schofield 2011, "Automated Leak Detection of Buried Tanks using Geophysical Methods at the Hanford Nuclear Site." SAGEEP 2011, Annual Meeting of the Enyironmen1al and Engineering Geophysical Society, Charleston. South Catolina. April 10-14.

Cardarelli, E. and G. Di Filippo. 2009, "Electrical Resistivity and Induced Polarization Tomography in Identifying the Plume of Chlorinated Hydrocarbons in Sedimentary Formation: A Case Study in Rho (Milan. Italy), "Waste Management and Research 27:595. 
Cassiani, G., V. Bruno, A. Villa, N. Fusi, A.M. Binley, 2006, "A Saline Trace Test Monitored via Time-Lapse Surface Electrical Resistivity Tomography," Journal of Applied Geophysics 59:244-259.

CEES-0333. 2006, Quality Assurance Plan for Surface Geophysical Exploration Projects. as revised, Columbia Energy and Environmental Services Inc., Richland, Washington.

CEES-0338, 2006, Software Management Plan for Surface Geoplysical Exploration Projects, Revision 0. Columbia Enerey and Environmental Services Inc., Richland, Washington.

CEES-0360, 2007, Suface Geophysical Exploration System Design Description. Revision 0, Columbia Energy and Environmental Services, Inc., Richland, Washington.

CE-ES-3.5, 2011, Software Engineering, as revised. Columbia Energy and Environmenta] Services, Inc., Richland, Washington.

Chambers, JE., P.B. Wilkinson, G.P. Wealthall, M.H. Loke, R. Dearden, R. Wilson, R.D. Ogilvy, 2010, "Hydrogeophysical Imaging of Deposit Heterogeneity aud Groundwater Chemistry Changes during DNAPL Source Zone Bioremediation," Jounat of Contaminam Hydrology 118:43-91.

Chen, J., S. Hubbard, and Y. Rubin, 2001. "Estimating the Hydraulic Conductivity at the South Oyster Site from Geophysical Tomographic Data Using Bayesian Techniques Based on the Nornal Libear Regression Model," Water Resources Research 37:1603-1613.

Contract 28090, Requisition 123974, High Resolution Resistivity Characterization of Single Shell Tank Farm Waste Mamagement Areas, Revision 3, CH2M HIL Hanford Group, Inc.

Daily. W. A. Ramirez. R. Newmark, R., and K. Masica, 2004. "Low-Cost Reservoir' Tomographs of Electrical Resistivity," The Leading Edge 23(5); 472-480.

Day-Lewis, F.D., K. Singha, and A.M. Binley, 2005, "Applying Petrophysical Models to Radar Travel Time and Electrical Resistivity Tomograms: Resolution-Dependent Limitations." Journal of Geophysical Research 110: B08206.

deGroot-Hedlin, C. and S. Constable, 1990. "Occam's Inversion to Generate Smooth, Two-Dimensional Models from Magnetotelluric Data," Geophysics 55(12):1613-1624.

Dey. A. and H. F. Morrison, 1979. "Resistivity Modeling For Arbitrarily Shaped Three-Dimensional Structures." Geophysics 44(4):753-780.

DOE O 414.1C. 2005, Quality Assurance, U.S. Department of Energy, Washington, D.C.

DOE-GJO, 1998, Vadose Zonte Characterization Project at the Hanford Tank Farms BX Tank Farm Report, GJPO-HAN-19. U.S. Departnent of Energy, Grand Junction Office, Grand Junction. Coloraso.

Ellis, R. G., and D. W. Oldenburg, 1994, "Applied Geophysical Inversion," Geophysical Joumal International 116: 5-11. 
Ezzedine, S., Y. Rubin, and J. Chen, 1999, "Bayesian Method for Hydrogeological Site Characterization Using Borehole and Geophysical Survey Data: Theory and Application to The Lawrence Livermore National Laboratcy Superfund Site," Water Resources Research 35: 2671-2683.

Fecht, K.R., S.P. Reidel, and A.M. Tallman, 1985, "Paleodrainage of the Columbia River System on the Columbia Plateau of Washington State - A Summary," in Selected Papers on the Geology of Washington. J.E. Schuster. ed.. Washington Division of Geology and Earth Resources. Bulletin 77, p. 219-248.

Geomatrix, 2005, Evaluation of Geophysical Technologies for Subsurface Characterization, Project Number 10960, Geonatrix Consultants, Inc., Denver, Colorado.

Gephart. R.E. and R.E. Lundgren, 1995. Hanford Tatk Clean Up: A Guide to Understanding the Technical Issues, Pacific Northwest National Laboratory. Richland, Washington.

Gephart, R.E., 2010, "A Short History of Waste Management at the Hanford Site," Physics and Chemistry of the Earth. Parts A/B/C, 35: 298-306.

Glaser. D.R.. J.B.. Fink, M.T. Levitt, and D.F. Rucker. 2008. A Sumnary of Recent Geophysical Investigations at the Deparment of Energy Hanford Nuclear Facility, Abstract \#B-04. American Geophysical Union. Chapman Conference on Biogeophysics. Portland, Maine, 12-16 Oct.

Gray. R.H.. R.E. Jaquish. P.J. Mitchell, and W.H. Rickard, 1989 "Environmental Monitoring at Hanford, Washington, USA: A Brief Site History and Summary of Recent Results," Environmental Managemest 13:563-572.

HNF-EP-0182-280. Waste Tank Sumnary for the Month Ending July 31, 2011, Fluor Hanford, Inc., Richland, Washington.

Johnson, T.C., R.J. Versteeg, A. Ward, F.D. Day-Lewis, and A. Revil, 2010, "Improved Hydrogeophysical Characterization and Monitoring through Parallel Modeling and Inversion of Time-Domain Resistivity and Induced-Polarization Data." Geophysics 75:WA27-WA41.

Khaleel, R., M.D. White, M. Oostrom, M.L. Wood, F.M. Mann, and J.G. Kristofzski, 2007. "Impact Assessment of Existing Vadose Zone Contamination a1 the Hanford Site SX Tank Faim," Vadose Zonte Joumal 6:935.

Lindsey. K.A., 2009. "Geologic Features in the Columbia River Basalt Groupe CRBG) Aquifer System that Form Vertical Flow Pathways and Subdivide the Regional Groundwater Flow Systen: Examples from the Columbia Basin Ground Water Management Area (GWMA) of South-Central Washington." proceedings of the annual GSA meeting, Portland, Oregon.

Loke, M.H., I. Acworth, and T. Dahlin, 2003, "A Comparison Of Smooth And Blocky Inversion Methods in 2D Electrical Imaging Surveys," Exploration Geophysics 34:82-187.

Loke, M.H.. P.B. Wilkiuson, and J.C. Chambers, 2010, "Fast Computation of Optimized Electrode Arrays for 2D Resistivity Surveys," Conputers and Geosciences 36:1414-1426. 
Martinho, E., M.M. Abreu, M.E. Pampulha, F. Alegria, A. Oliveira, and F. Almeida, 2010, “An Experimental Study of the Diesel Biodegradation Effects on Soil Biogeophysical Parameters," Water, Air, and Soil Pollation 206:139-154.

McKinley, J.P., J.M. Zachara, C. Liu, and S.M. Heald, 2006. "Microscale Controls on the Fate of Contaminant Uranium in the Vadose Zone, Hanford Site, Washington," Geochim. Cosmochim. Acta 70(8):1873-1887.

Moysey. S. and R. Knight. 2004, "Modeling the Field-Scale Relationship Between Dielectric Constant and Water Content in Heterogeneous Systems," Water Resources Research 40:W03510.

Ntarlagiannis, D., K.H. Williams, L. Slater, and S. Hubbard, 2005, "Low-Frequency Electrical Response to Microbial Induced Sulfide Precipitation." Joumat of Geophysical Research 110:G02009.

Oostrom, M., T.W. Wietsmi, J.H. Dane, M.J. Truex, and A.L. Ward, 2009, "Desiccation of Unsalurated Porous Media: Intermediate-Scale Experinents and Numetical Sinulation." Vadose Zone Journal 8:643.

Patella, D., 1983, "On the Relationship Between Apparent Resistivity Functions in the Case of Complicated Underground Structures," Geophysics 48:1398-1401.

PNNL-14128, 2002, Characterization of Vadose Zonte Sediment: Borehole C3103 Located in the 216-B-7A Crib Near the B Tank Fam, Pacific Northwest National Laboratory, Richland, Washinglon.

PNNL-16887, 2007, Geologic Descriptions for the Solid-Waste Low Level Burial Groutds, Pacific Northwest National Laboratory, Richland, Washington.

PNNL-17821, 2008, Electrical Resistivity Corretation to Vadose Zone Sediment and Pore-Water Composition for the BC Cribs and Trenches Area. Pacific Northwest National Laboratory, Richland, Washington.

PNNL-20209, 2011, Implementation Plan for the Deep Vadose Zone-Applied Field Research Center, Pacific Northwest National Laboratory. Richland, Washington.

Ramirez, A.L., R.L. Newmark, and W.D. Daily, 2003. "Monitoring Carbon Dioxide Floods Using Electrical Resistance Tomography (ERT): Sensitivity Studies," Jownal of Envirommental and Engineering Geophysics 8:187-198.

RPP-10098, 2002, Field Investigation Repon for Waste Management Area B-BX-BY, Revision 0 . CH2M HILL Hanford Group. Inc.. Richland, Washington.

RPP-15808, 2003, Subsarface Conditionts Description of the U Waste Management Area, Revision 0, CH2M HLL Hanford Group. Inc., Richland. Washington

RPP-23748, 2006, Geology, Hydrogeology, Geochemistry, and Mineralogy Data Package for the Sintgle-Shell Tatk Waste Managentent Areas at the Hanford Site, Revision 0 , CH2M HILL Hanford Group. Inc.. Richland, Washington.

RPP-23752, 2005, Field Investigation Report for Waste Managenem Areas $T$ and TX.TX, Revision 0-A. D.A. Myers, C.H2M HIL Hanford Group, Inc., Richland. Washington. 
RPP-30121, 2006, Tank 241-S-102 High Resolutiof Resistivity Leak Detection and Monitoring Testing Report, CH2M HLL Hanford Group, Inc., Richland, Washington.

RPP-34974, 2007, Verification and Testing of the Earthmager Series of Electricat Resistivity Inversion Codes - A Benchmark Comparison, Revision 0. CH2M HILL Hanford Group, Inc.. Richland. Washington.

RPP-35484, 2007, Field Investigation Report of Waste Management Areas C and A-AX, Revision 1, C.H2M HILL Hanford Group, Inc, Richland, Washington.

RPP-5957, 2000, Historical Vadose Zone Contamination from T, TX, and TY Tank Farm Operations, Revision 0, CH2M HILL Hanford Group Inc.. Richland. Washington.

RPP-7578, 2000, Site-Specific SST Phase 1 RFI/CMS Work Plan Addendum for WMAs Tand $T X-T Y$, Revision 2, C.H2M HILL Hanford Group. Inc.. Richland. Washington.

RPP-ASMT-42278, 2009, Tank 241-A-103 Leak Assessment Repon, Revision 0, Washington River Protection Solutions, LLC., Richland, Washingtou.

RPP-ASMT-47140, 2010. Tank 241-SX-110 Leak Assessment Report. Revision 0. Washington River Protection Solutions, LLC., Kichland, Washington.

RPP.ENV-33418, 2008. C Farm Leak Assessments Report: 241-C.101, 241-C.110, $241 . C .111$. 241-C.-105, and Unplanned Waste Reteases. Revision 1, CH2M HILL Hanford Group. Inc, Richland, Washington.

RPP-PLAN-39114. Phase 2 RCRA Facility Investigation/Corrective Measures Study Wonk Plan for Waste Management Area C, CH2M HIL Hanford Group, Inc., Richland. Washington.

RPP-RPT-28955, 2006. Surface Geophysical Exploration of T Tank Farm at the Hanford Site, Revision 0, CH2M HILL Hanford Group. Inc, Richland, Washington.

RPP-RPT-30976, 2006, Surface Geophysical Exploration of S Tank Farm at the Hanford Site, CH2M HILL Hanford Group, Inc., Richland, Washington.

RPP-RPT-42296, 2010, Hanford TY-Fam Leak Assessments Report, Revision 0. Washington River Protection Solutions. LLC. Richland, Washington.

RPP-RPT-43704, 2011. Hanford BY-Fam Leak Assessments Report, Washington River Protection Solutions, LLC, Richland, Washington.

RPP-RPT-46088, 2010. Flow and Transport in the Natural System at Waste Management Area $C$. Washington River Protection Solutions, LLC.. Richland. Washington.

RPP-RPT-48490, 2011, Technical Approach and Scope for Flow and Contaninant Transpont Analysis in the Intifial Performance Assessment of Waste Management Area $C$. Washington River Ptotection Solutions. LLC., Richland, Washington.

RPP-RPT-48589, 2011, Hanford 241-S Farm Leak Assessment Report, Revision 0, Washington River Protection Solutions, LLC., Richland, Washington.

RPP-RPT-49129, 2011, Three-Dimensional Surface Geophysicat Exploration of the BY Tank Farm, Revision 0, Washington River Protection Solutions, LLC, Richland, Washington. 
RPP-RPT-50052, 2011, Surface Geophysical Exploration of UPR-200-E-82 Near the C Tank Farm, Revision 0, Washington River Protection Solutions, LLC, Richland, Washington.

Rucker, D. F.. 2010, "The Application Of Magnetic Gradionetry and Electronagnetic Induction at a Former Radioactive Waste Disposal Site," Waste Management and Research 28:364.

Rucker, D.F., G.E. Noonan, and W.J. Greenwood, 2011, "Electrical Resistivity In Support of Geological Mapping Along the Panama Canal." Engineering Geology 117:121-133.

Rucker. D.F., M.H. Loke, M.T. Levitt, and G.E. Noonan, 2010. "Electrical-Resistivity Characterization of an Industrial Site Using Long Electrodes," Geopflysics 75:WA95.

Rucker, D.F., M.T. Levitt, and W.J. Greenwood, 2009, "Three-Dimensional Electrical Resistivity Model of a Nuclear Waste Disposal Site." Jounat of Applied Geophysics 69:150-164.

Rucker, D.F., M.T. Levitt, D.A. Myers, and C. Henderson, 2008, "Debelopment of an Electrical Resisitivity Imaging Program for Subsurface Characterization at Hanford," proceedings of the Waste Management Converence, WM2008. Tucson. Arizona.

Rucker, D.F, and J.B. Fink, 2007. "Inorganic Plume Delineation using Surface High Resolution Electrical Resistivity at the BC Cribs and Trenches Site. Hanford," Vadose Zone Journal, in press.

Sasaki, Y.. 1989, "Two-Dimensional Joint Inversion of Magnetotelluric and Dipole-Dipole Resistivity Data," Geophysics 54:254.

Schön, 1996, Schon, J.H., 1998, Physical Properties of Rocks - Fundamentals and Principles of Petrophysics, Handbook of Geophysical Exploration: Seisnic Exploration, Volume 18, New York, Elsevier.

Singha, K. and S. Moysey, 2006, "Accounting for Spatially Variable Resolution in Electrical Resistivity Tomography through Field-Scale Rock-Physics Relations." Geophysics 71:A25.

Singha, K. and S.M. Gorelick. 2006, "Etfects of Spatially Variable Resolution on Field-Scale Estimales of Tracer Concentration from Electrical Inversions Using Archie's Law," Geophysics 71:G83.

Slater et al.. 2000. "Cross-hole Electrical Imaging of a Controlled Saline Tracer Injection." Joumal of Applied Geophysics 49:211-229

Sogade, J. A., F. Scira-Scappuzzo, Y. Vichabian, W. Shi, W. Rodi, D.P. Lesmes, 2006. "Induced-Polarization Detection and Mapping Of Contaminant Plumes," Geophysics 71:B75-B84.

Steefel. C. I.. S. Camoll, P. Zhao. and S. Roberts, 2003. "Cesium Migration In Hanford Sediment: A Multisite Cation Exchange Model Based on Laboratory Transport Experiments." Journat of Contaminant Hydrology, 67, 219-246.

Stunmer. P., H. Maurer, and A.G. Green. 2004. "Experimental Design: Electrical Resistivity Data Sets that Provide Optimum Subsurface Information." Geopiysics 69(1):120-139. 
Telford, W.M., L.P. Geldart, and R.E. Sheriff, 1990, Applied Geophysics, $2^{\text {nd }}$ ed., Cambridge University Press, Cambridge, United Kingdom.

Udphuay. S., T. Gunther. M.E. Everett, R.R. Warden, and J.L. Briaud. 2011, "ThreeDimensional Resistivity Tomography in Extreme Coastal Terrain Amidst Dense Cultural Signals: Application to Cliff Stability Assessment at the Historic D-Day Site," Geophysical Journat Intertational 185:201-220.

Un, W., J.P. Icenhower, C.F. Brown, R.J. Serne. Z. Wang, and C.J. Dodge, 2010, "Characterization of Uranium-Contaminated Sediments From Beneath a Nuclear Waste Storage Tank From Hanford, Washington: Implications for Contaminant Transport and Fate," Geochimica et Cosmochimica Acta 74:1363-1380.

Vaudelet, P., A. Revil, M. Schmutz, M. Franceschi. P. Bégassat, 2010. "Induced Polatization Signatures of Cations Exhibiting Differential Sortion Behaviors in Saturated Sands," Water Resources Research 47:W02526.

Vaudelet, P., A. Revil, M. Schmutz, M. Franceschi, P. Bégassat, 2011, "Changes In Induced Polarization Associated With the Sorption of Sodjum. Lead, and Zinc on Silica Sands," Joumat of Colloid and Interface Science 360:739-752.

Vickery, A.C. and B.A. Hobbs, 2002, "The Effect of Subsurface Pipes on Apparent-Resistivity Measurements," Geophysical Prospecting 50(1): 1-13.

Wait, J.R. and K.R. Umashankar, 1978. "Analysis of the Earth Resistivity Response of Buried Cables." Pure and Applied Geophysics 117: 711-742.

Wait, J.R., 1978, "Some Earth Resistivity Problenns Involving Buried Cables," Quktrerty of the Cotorado School of Mines 73:1-21.

Ward. A.L, Z.F. Zhang. and G.W. Gee, 2006, "Upscaling Unsalurated Hydraulic Parameters for Flow Through Heterogeneous Anisotropic Sediments," Advances in Water Resources 29(2):268-280.

Weast, R., ed., 1986, CRC Handhook of Chemistry azd Physics. 67th ed., CRC Press. Inc.. Boca Raton. Florida.

WHC-MR-0227, 1991. Tank Wastes Discharged Divectly to the Soil at the Hanford Site, Westinghouse Hanford Company, Richland, Washington.

WHC-MR-0391, 1992. Field Trip Guide to the Hanford Site. Westinghouse Hanford Company. Richland, Washington.

WHC-SD-WM-ER-575, 1996, Ligtid Radioactive Waste Discharges from B-Plant to Crib, Revision 0, Westinghouse Hanford Company, Richland, Washington.

Wilkinson, P.B.. P.I. Meldrum, J.E. Chambers, O. Kuras and R.D, Ogilvy. 2006. "Improves Strategies for the Automalic Selection of Optimized Sets of Electrical Resistivity Tomography Measurement Configurations," Geophysical Journal International 167(3):1119-1126. 
WRPS-50043, 2011, Surface Gecphysical Exploration: Developing Nonimasive Tcols to Montifer Past Leaks around Hanford's Tank Fams, Revision 0. Washington River Protection Solutions. LLC. Richland. Washington.

Yeh. T.C. J.. L.W. Gelhar, and A.L. Gutjahr. 1985, "Stochastic Analysis of Unsaturated Flow in Heterogeneous Soils, 3: Observations and Applications," Water Resources Research 21(4):465-471.

Zachara. J. M.. J. Serne, M. Freshley, F. Mann, F. Anderson, M. Wood. T. Jones, and D. Myers, 2007. "Geochemical Processes Controlling Migration High Level Wastes in Hanford's Vadose Zone," Vadose Zone Joumal 6:985. 